FAGNER ALEXANDRE NUNES DE FRANÇA

\title{
Ensaios de arrancamento em solo grampeado executados
}

\section{em laboratório}

\begin{abstract}
Dissertação apresentada à Escola de Engenharia de São Carlos da Universidade de São Paulo, como parte dos requisitos para a obtenção do Título de Mestre em Geotecnia.
\end{abstract}

Orientador: Prof. Dr. Bendito de Souza Bueno

São Carlos 

À minha noiva amada e à minha família querida. 



\section{AGRADECIMENTOS}

Agradeço a Deus pela oportunidade de vida e sucesso que me foi dada.

A minha querida noiva Marília, que, por todos estes anos, me acompanhou nos momentos difíceis, me auxiliou nas decisões tomadas, me apoiou nestas, enfim, me amou em toda a sua plenitude e que, assim também, a amo.

A minha família, distante, porém sempre presente no pensamento.

A Ozilda, minha mãe, um agradecimento especial pela formação que me deu, na qual me baseio em tantos momentos da vida e que me faz crescer diariamente, mesmo distante.

A Dilma Ottoni, sempre atuante com seus pensamentos positivos, orações e apoio constante em todos os momentos, de aflição e de felicidade.

A Nevinha e Eliana por todos os momentos de alegria e o eterno auxílio.

Aos meus amigos, grandes amigos, pela amizade construída com a convivência em São Carlos e que perdurará, certamente, sem a mesma.

Ao Prof. Dr. Benedito de Souza Bueno, sem o qual, este trabalho tornar-se-ia impossível.

Aos professores do Departamento de Geotecnia, em especial aos Professores Esquível, Orêncio, Cintra e Aoki, pelo apoio profissional e, principalmente, pessoal.

Aos professores da UFRN que contribuíram para minha formação acadêmica, em especial aos Professores Ricardo Amaral, Olavo Santos Júnior e Roberto Medeiros e ao companheirismo do Prof. Ricardo Severo e de Osvaldo de Freitas Neto.

A todos os funcionários do Departamento de Geotecnia da EESC-USP pelo apoio constante. 
Ao Conselho Nacional de Desenvolvimento Científico e Tecnológico (CNPq) e à Fundação de Amparo à Pesquisa do Estado de São Paulo (FAPESP) pelo apoio financeiro a esta pesquisa e ao Laboratório de Materiais Avançados à Base de Cimento pelo auxílio na pesquisa. 
"No meio de qualquer dificuldade encontra-se a oportunidade."

Albert Einstein 



\section{RESUMO}

FRANÇA, F. A. N. (2007). Ensaios de arrancamento em solo grampeado executados em laboratório. Dissertação (Mestrado) - Escola de Engenharia de São Carlos, Universidade de São Paulo, São Carlos, 2007.

Solo grampeado é uma alternativa eficiente utilizada em obras de reforço de solos. É resultante da inclusão de reforços, denominados grampos, em um maciço em corte. A resistência ao cisalhamento da interface solo-grampo é um dos parâmetros mais importantes para fins de projeto. Este parâmetro é determinado a partir da experiência dos projetistas e se baseia principalmente no tipo de solo e em ensaios de campo (arrancamento, sondagens a percussão e pressiométricos). Neste contexto, a realização de ensaios de arrancamento in situ é extremamente importante para a quantificação deste parâmetro e, conseqüentemente, para a elaboração de projetos mais econômicos e seguros. A execução de ensaios de arrancamento em laboratório permite verificar condições muitas vezes não encontradas em campo. Este trabalho apresenta os resultados de ensaios de arrancamento de grampos realizados em laboratório. Também foi analisada a evolução da força nos grampos e dos deslocamentos do solo. Os grampos foram instalados em um protótipo de solo grampeado sobre o qual se aplicou uma sobrecarga de $50 \mathrm{kPa}$ através de uma bolsa de ar comprimido. Os ensaios de arrancamento permitiram quantificar valores de resistência ao cisalhamento de interface da ordem de $145 \mathrm{kPa}$, mobilizados com pequenos deslocamentos dos grampos. $\mathrm{O}$ arrancamento de grampos instrumentados indicou que cerca de $90 \%$ do comprimento total dos grampos foi solicitado. Ao final dos ensaios de arrancamento, os grampos foram extraídos completamente do maciço de solo o que permitiu comprovar a sua integridade física. Os deslocamentos do solo foram máximos próximo ao topo do protótipo e na direção horizontal. Os resultados demonstram a viabilidade de estudar o comportamento do maciço reforçado a partir do comportamento do protótipo de solo grampeado construído em laboratório.

Palavras-chave: Solos grampeados. Ensaios de arrancamento. Resistência ao cisalhamento de interface. 



\section{ABSTRACT}

FRANÇA, F. A. N. (2007). Pullout tests in soil nailed wall built in laboratory. Dissertation (Master) - Escola de Engenharia de São Carlos, Universidade de São Paulo, São Carlos, 2007.

Soil nailing is an efficient soil reinforcement technique which uses inclusions, namely nails, in soil slopes. Unit skin friction is one of the most important parameters used in soil nailing design. The definition of this parameter is commonly based on local experience and correlations to some in situ tests. This work presents the results obtained from the pullout test carried out in a soil nailed wall prototype built in laboratory. Forces acting in nails were measured by strain gage instrumentation. Soil displacement was measured in short and long terms. The pullout tests were carried out after the application of a uniform surcharge given by a compressed air bag. The results showed that unit skin friction was about $145 \mathrm{kPa}$, mobilized with little nail displacements. About $90 \%$ of nail length were solicited during pullout tests, according to tests performed in strain gage instrumented nails. Nail extraction showed a high level of nail integrity. Soil displacements were higher close to the wall top, near the face. These results demonstrate the feasibility of using of laboratory prototype studies to investigate the geotechnical behavior of soil nailing structures.

Keywords: Soil nailing. Pullout tests. Unit skin friction. 



\section{LISTA DE FIGURAS}

Figura 2.1 - Aplicações mais comuns de solos grampeados: a - estabilização de taludes; b

- contenção de taldes em corte (adaptado de Guilloux e Schlosser, 1982).

Figura 2.2 - Métodos de execução de túneis (adaptado de FRENCH NATIONAL RESEARCH PROJECT CLOUTERRE, 1991).

Figura 2.3 - Primeiro muro em solo grampeado documentado, em Versailles, França (adaptado de FRENCH NATIONAL RESEARCH PROJECT CLOUTERRE, 1991).

Figura 2.4 - Etapas executivas da técnica de solos grampeados (SOLOTRAT ENGENHARIA GEOTÉCNICA, 2003).

Figura 2.5 - Tipos de ligações grampo-face. (a) Para barra com mais de $20 \mathrm{~mm}$ de diâmetro e (b) para barras com menos de $20 \mathrm{~mm}$ de diâmetro (adaptado de Ortigão, Palmeira e Zirlis, 1995).

Figura 2.6 - Comparação entre face em concreto projetado com malha de aço eletrossoldada (a) e concreto com fibras (b) (SOLOTRAT ENGENHARIA GEOTÉCNICA, 2003).

Figura 2.7 - Esquema de dreno subhorizontal profundo (SOLOTRAT ENGENHARIA GEOTÉCNICA, 2003).

Figura 2.8 - Comparação entre cortinas atirantadas (a) e solo grampeado (b) (adaptado de Ortigão, Palmeira e Zirlis, 1995).

Figura 2.9 - Representação dos pontos de deslocamentos horizontais máximos da face na técnica de solos grampeado (a) e da terra armada (b).

Figura 2.10 - Esquema de deformação de uma barra submetida a cisalhamento ao longo de uma superfície potencial de ruptura (adaptado de Schlosser, 1982).

Figura 2.11 - Carregamento progressivo de um grampo em solo grampeado devido ao processo de escavação (FRENCH NATIONAL RESEARCH PROJECT CLOUTERRE, 1991).

Figura 2.12 - Zonas ativa e passiva características de contenções em solo grampeado (EHRLICH; SILVA; 1992).

Figura 2.13 - Influência da rigidez do grampo nas deformações e tensões mobilizadas (EHRLICH, 2003, adaptado de Jewell, 1990).

Figura 2.14 - Variação do coeficiente de empuxo com a profundidade em solos grampeados (adaptado de Guilloux e Schlosser, 1982). 
Figura 2.15 - Mecanismos de ruptura em solos grampeados (adaptado de FRENCH NATIONAL RESEARCH PROJECT CLOUTERRE, 1991).

Figura 2.16 - Mecanismos clássicos de instabilização de estruturas de contenção. (a) Deslizamento. (b) Tombamento. (c) Capacidade de carga das fundações. (d) Ruptura global (adaptado de Vertematti et al., 2004).

Figura 2.17 - Limites da área onde devem ser executadas as investigações geotécnicas. (a) Taludes sem inclinação à montante. (b) Talude com inclinação à montante (FRENCH NATIONAL RESEARCH PROJECT CLOUTERRE, 1991).

Figura 2.18 - Esquema para ensaios de arrancamento em diferentes camadas de solo (FRENCH NATIONAL RESEARCH PROJECT CLOUTERRE, 1991).

Figura 2.19 - Esquema para ensaios de arrancamento in situ em solos grampeado (FRENCH NATIONAL RESEARCH PROJECT CLOUTERRE, 1991).

Figura 2.20 - Critérios de ruptura utilizados nos ensaios de arrancamento (FRENCH NATIONAL RESEARCH PROJECT CLOUTERRE, 1991).

Figura 3.1 - Dimensões internas da caixa de ensaio metálica utilizada nesta pesquisa (a) e face frontal adaptada para a construção do protótipo de solo grampeado (b)...............76

Figura 3.2 - (a) Curva granulométrica e (b) curva de compactação com energia normal obtidas para o solo utilizado nesta pesquisa.

Figura 3.3 - Suportes utilizados para a perfuração com inclinação de $10^{\circ} \mathrm{com}$ a horizontal (a) e detalhe do trado utilizado nesta operação (b)

Figura 3.4 - Moldagem de corpos de prova da calda de cimento durante a execução de uma linha de grampos (a) e exemplo dos mesmos em cura submersa (b).

Figura 3.5 - Evolução da resistência à compressão uniaxial da calda de cimento segundo o tempo de cura submersa.

Figura 3.6 - Localização dos grampos no protótipo de solo grampeado com destaque para as seções verticais centrais, instrumentadas com strain gages.

Figura 3.7 - Seção vertical central do protótipo de solo grampeado, tomada como representativa do comportamento do mesmo.

Figura 3.8 - Calibração dos strain gages: a) Equipamentos utilizados no procedimento;

b) Gráficos típicos produzidos no processo de calibração dos strain gages.

Figura 3.9 - Relógios comparadores utilizados para medição dos deslocamentos do protótipo durante a construção.

Figura 3.10 - Curvas de calibração do forno microondas para o solo utilizado nesta pesquisa. 
Figura 3.11 - Fotos ilustrativas do controle de compactação pelo método do cilindro de cravação.

Figura 3.12 - Fotos ilustrativas do procedimento manual de compactação: a - antes do lançamento do solo; b - solo lançado; c - espalhamento manual com enxada; $d$ compactação com soquete manual.

Figura 3.13 - Camadas do maciço de solo compactado utilizado para a construção do protótipo de solo grampeado.

Figura 3.14 - Simulação do processo de escavação do maciço de solo através da remoção de um segmento da face de madeira.

Figura 3.15 - Instalação dos grampos: a - perfuração com trado manual; b preenchimento do furo com calda de cimento, por gravidade.

Figura 3.16 - Equipamentos utilizados nos ensaios de arrancamento. a - vista geral. b vista detalhada.

Figura 3.17 - Adaptação dos equipamentos utilizados nos ensaios de arrancamento para a extração completa dos grampos.

Figura 4.1 - Resultados dos ensaios de arrancamento executados nesta pesquisa. 96

Figura 4.2 - Resistência ao cisalhamento de interface versus profundidade dos grampos em valores absolutos e médios.

Figura 4.3 - Evolução do comprimento solicitado durante os ensaios de arrancamento executados nos grampos instrumentados (4-4, 6-4 e 6-5). Foram plotados quatro níveis de carregamento em relação à força de arrancamento.

Figura 4.4 - Exemplos de grampos submetidos à extração completa.

Figura 4.5 - Evolução dos deslocamentos medidos durante a construção do protótipo em solo grampeado.

Figura 4.6 - Deslocamentos horizontais da face após a aplicação da sobrecarga (50kPa). . 111

Figura 4.7 - Gráficos típicos da evolução da força de tração nos grampos instrumentados. 114

Figura 4.8 - Força de tração ao longo dos grampos. A linha tracejada indica a posição da superfície potencial de ruptura sugerida para cada situação: a - Fim de construção; b - Após aplicação da sobrecarga. 


\section{LISTA DE TABELAS}

Tabela 2.1 - Definição do tipo de proteção contra corrosão a ser utilizada em cortinas atirantadas e aplicada aos solos grampeados

Tabela 3.1 - Resumo da caracterização geotécnica do solo utilizado nesta pesquisa. .............78

Tabela 3.2 - Teores de umidade obtidos em estufa e no forno de microondas. ......................86

Tabela 4.1 - Resultados dos ensaios de arrancamento. ...................................................98

Tabela 4.2 - Valores da resistência ao cisalhamento da interface solo-grampo (adaptado de BYRNE et al., 1998). ..................................................................................... 100

Tabela 4.3 - Força nos grampos para os quatro níveis de carregamento analisados nesta

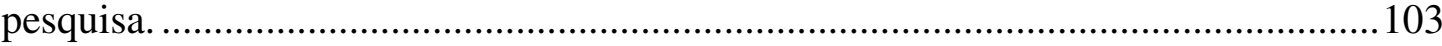

Tabela 4.4 - Taxa média de incremento dos deslocamentos medidos $(\mathrm{mm} / \mathrm{dia})$.................. 108 


\section{SUMÁRIO}

Capítulo 1 - Introdução..................................................................................................... 23

Capítulo 2 - Revisão Bibliográfica .............................................................................. 26

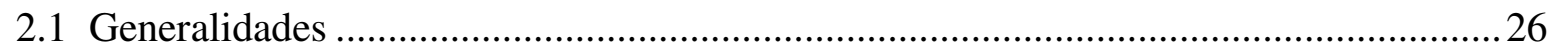

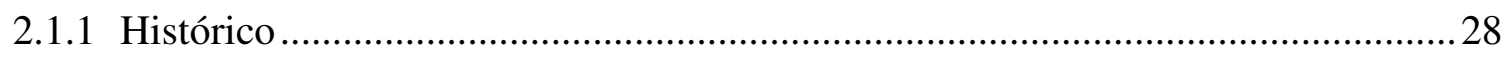

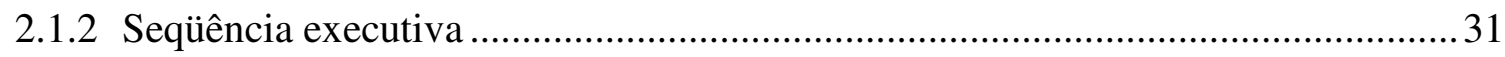

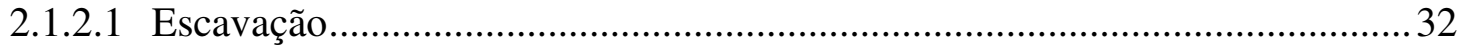

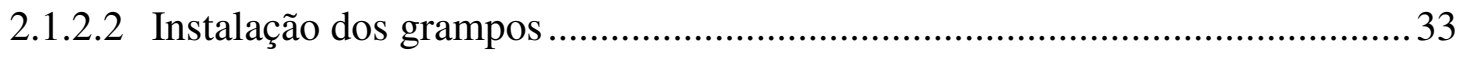

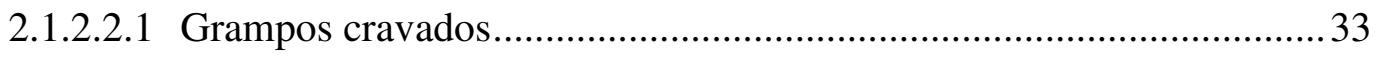

2.1.2.2.2 Grampos envoltos em calda de cimento ......................................... 33

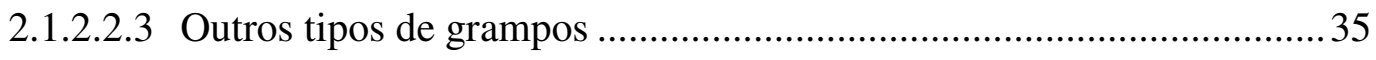

2.1.2.2.4 Proteção dos grampos contra a corrosão.............................................. 36

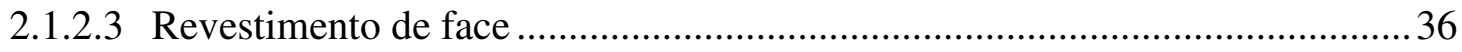

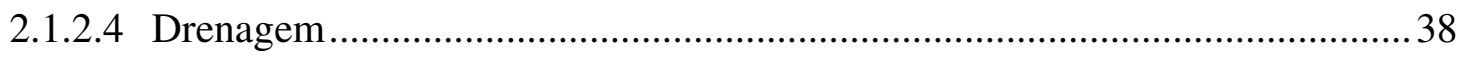

2.1.3 Vantagens da técnica de solo grampeado...................................................... 40

2.1.4 Limitações da técnica de solo grampeado....................................................... 41

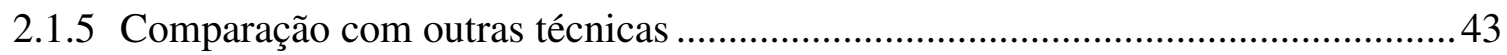

2.1.5.1 Comparação com cortinas atirantadas ........................................................ 43

2.1.5.2 Comparação com terra armada ................................................................ 45

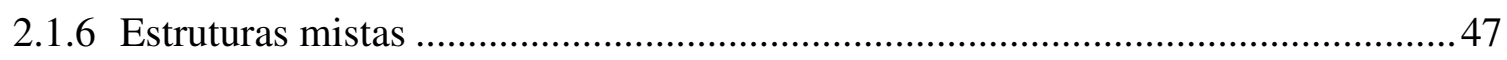

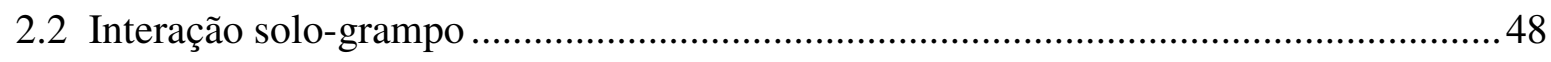

2.2.1 Resistência ao cisalhamento da interface entre o solo e o grampo .........................48

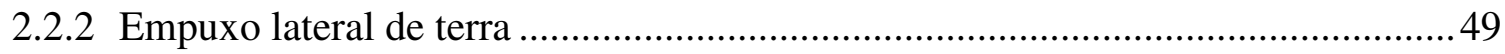

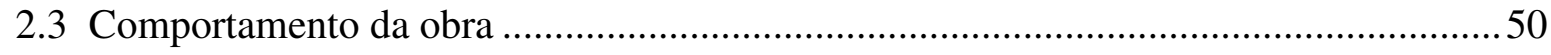




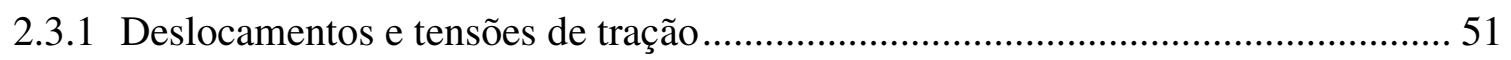

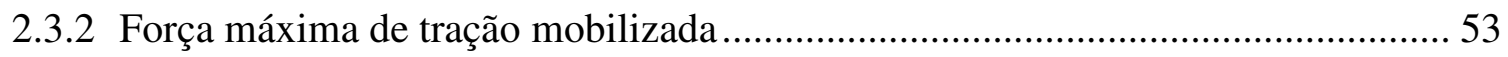

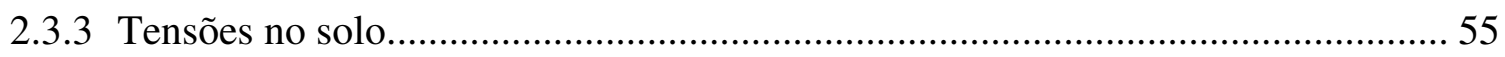

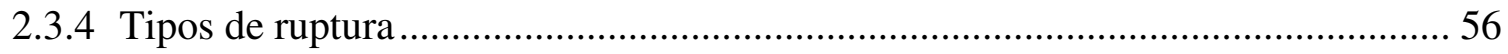

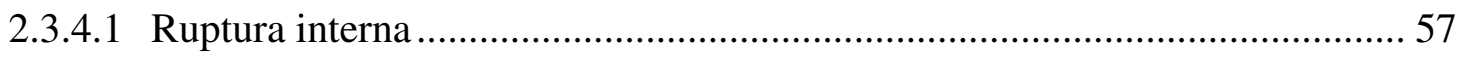

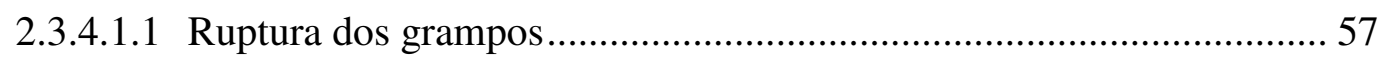

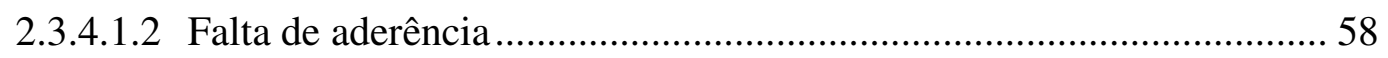

2.3.4.1.3 Altura de escavação excessiva ........................................................ 59

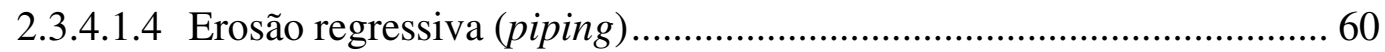

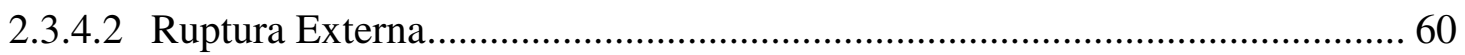

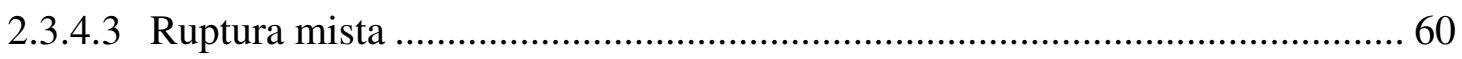

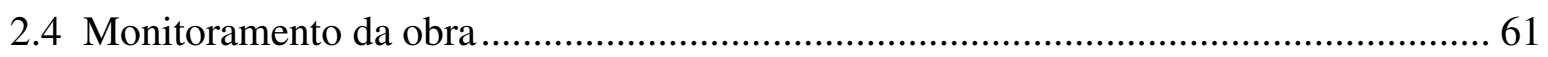

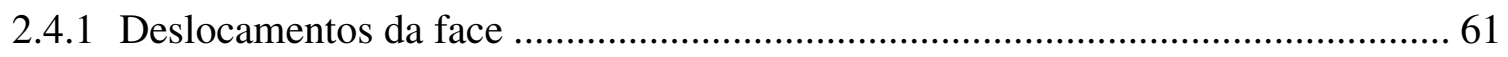

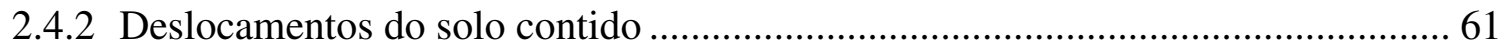

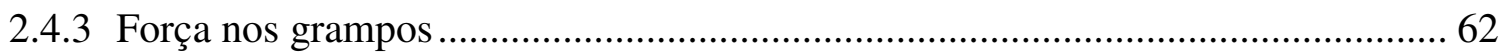

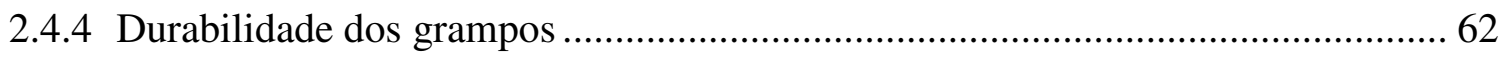

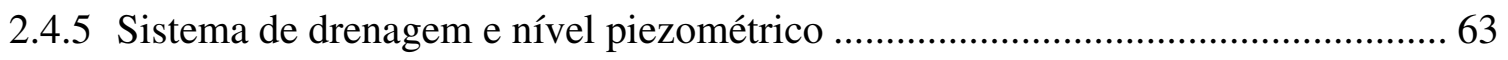

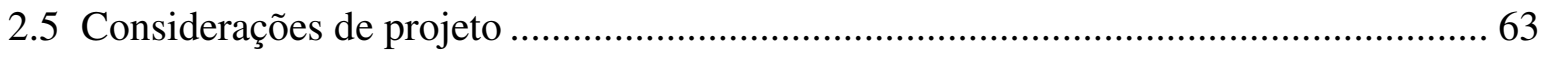

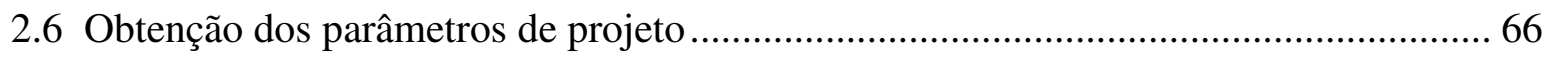

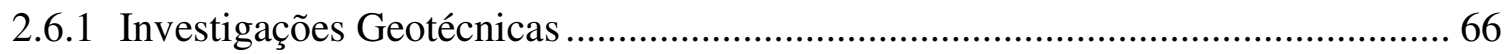

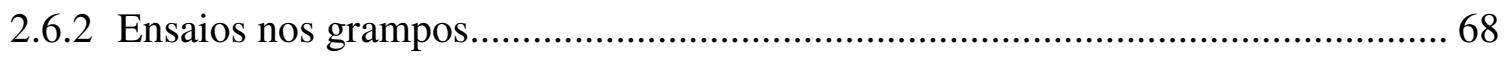

Capítulo 3 - Materiais e Métodos ........................................................................75

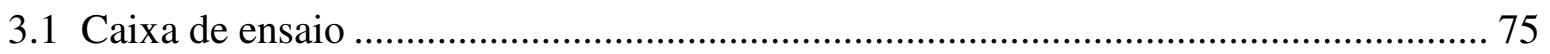

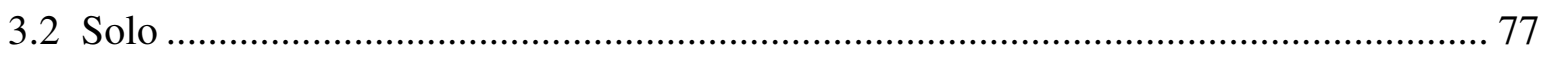

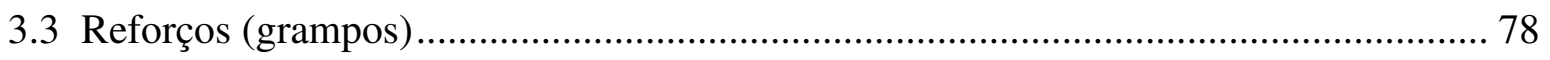




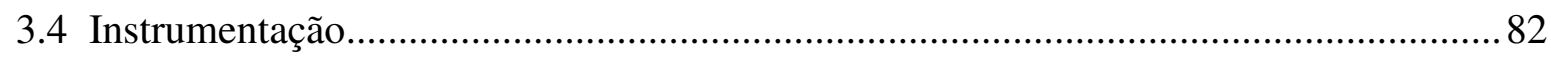

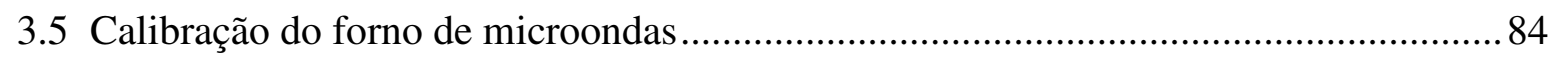

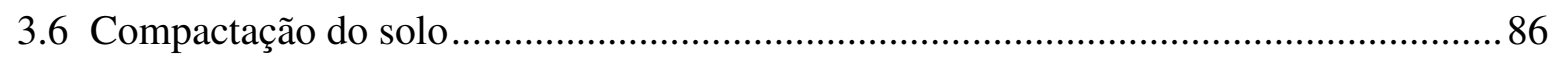

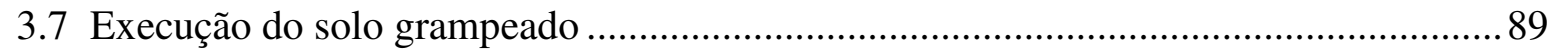

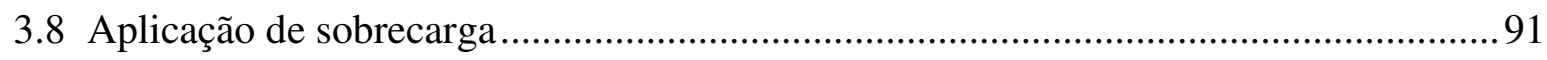

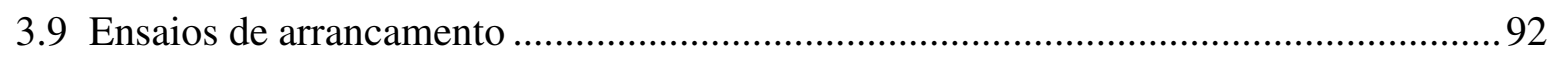

Capítulo 4 - Apresentação e Análise dos Resultados ....................................... 94

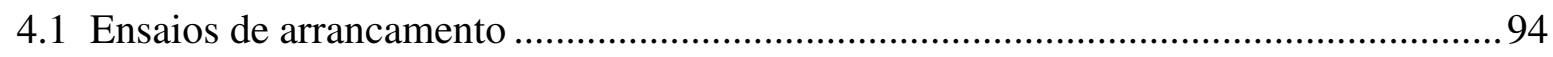

4.1.1 Ensaios de arrancamento nos grampos instrumentados .................................. 102

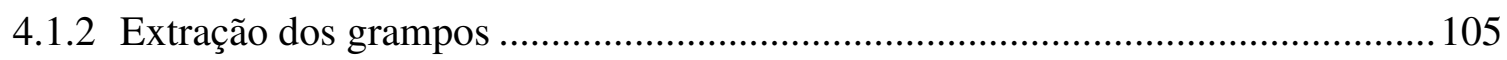

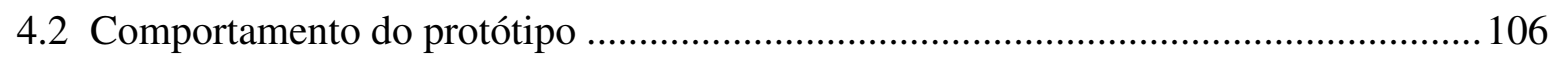

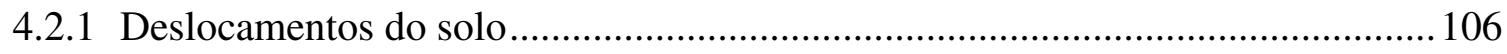

4.2.1.1 Deslocamentos do solo durante a construção do protótipo............................ 107

4.2.1.2 Deslocamentos do solo após a construção do protótipo ……….................... 110

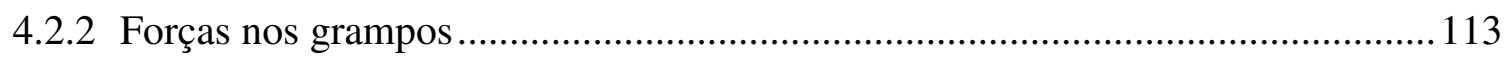

4.2.2.1 Sugestão de uma superfície potencial de ruptura....................................... 115

Capítulo 5 - Conclusões................................................................................................... 118

Referências ...................................................................................................... 121 



\section{Capítulo 1 - Introdução}

O reforço de solo é uma alternativa eficiente para a construção de taludes íngremes, sejam em corte ou em aterro. As estruturas de solo reforçado têm por objetivo restringir as deformações do meio reforçado (solo e inclusões) e do solo adjacente. Bruce e Jewell (1986) definem reforço in situ como a introdução de inclusões no solo para manter o equilíbrio devido ao peso próprio e às sobrecargas aplicadas acima do terreno.

Entre as técnicas mais comuns de reforço do solo, destaca-se a de solo grampeado que resulta da introdução de reforços, esbeltos e sem pré-tensionamento, em um maciço em corte. O procedimento é concluído, de forma geral, com um revestimento de face feito com concreto projetado, armado com tela de aço eletrossoldada, ou com adição de fibras de aço. $\mathrm{O}$ solo grampeado permite a construção de taludes íngremes em corte, o que possibilita um maior aproveitamento do espaço e reduz os custos com escavações.

Os parâmetros envolvidos nos projetos de solo grampeado relacionam-se com os solos do local da obra e com elementos como grampos, revestimento da face e sistema de drenagem. Os projetos de solo grampeado consideram as condições de ruptura interna e externa da obra. Um parâmetro fundamental nestas avaliações é a resistência ao cisalhamento 
da interface solo-grampo. Este parâmetro é obtido através de ensaios em campo ou por meio de correlações. CLOUTERRE (1991), por exemplo, apresenta correlações entre a resistência ao cisalhamento de interface e resultados de ensaios pressiométricos, enquanto Byrne et al. (1998) apresenta faixas de variação para a resistência ao arrancamento de grampos em função dos tipos de solos. Contudo, ambas as publicações citadas recomendam que os valores estimados sejam comprovados por ensaios em campo, executados antes e durante o andamento da obra.

Estudos elaborados por vários autores apresentam ensaios de arrancamento de grampos em pequena dimensão, em que um único grampo (CHU; YIN, 2005) ou uma linha de grampos (JUNAIDEEN et al.,2004) são avaliados. Este tipo de ensaio apresenta a vantagem de permitir que as condições de contorno sejam alteradas ao longo do estudo, como o teor de umidade e o grau de compactação do solo. Contudo, os ensaios em pequenas dimensões não permitem verificar o comportamento real da obra, pois não permitem a modelagem da seqüência construtiva ou dos níveis de tensões presentes.

Ensaios em centrífugas apresentam-se como uma alternativa para verificar o comportamento de obras de solo grampeado (ZHANG et al., 2001; e TEI; TAYLOR; MILLIGAN, 1998). Embora simulem de forma aceitável a geometria e o nível de tensões da obra e, portanto, o seu comportamento, os ensaios em solos grampeados realizados em centrífugas não permitem a execução de ensaios de arrancamento dos grampos.

A construção de modelos de solo grampeado em grandes dimensões mostra-se como uma alternativa viável para o estudo do comportamento desse tipo de obra, bem como para a execução de ensaios de arrancamento. Nem todos os trabalhos experimentais executados até então foram concebidos para verificar estes dois aspectos. Raju, Wong e Low (1997), por exemplo, construíram um modelo de solo grampeado com 2,4 m de altura para 
verificar o seu comportamento em relação aos deslocamentos do solo e às forças nos grampos. Eles, contudo, não realizaram ensaios de arrancamento.

A presente pesquisa visou ampliar o entendimento da interação solo-grampo. Desta forma constituiu objetivo principal do trabalho a determinação da resistência ao cisalhamento de interface solo-grampo através de ensaios de arrancamento dos grampos. O objetivo secundário do trabalho consistiu na análise da distribuição das forças desenvolvidas nos grampos, bem como na verificação dos deslocamentos externos do maciço reforçado. 


\section{Capítulo 2 - Revisão Bibliográfica}

Este capítulo apresenta uma revisão bibliográfica ampla sobre solo grampeado. Entendeu-se que a apresentação dos conceitos básicos do método e dos principais detalhes construtivos auxiliaria o leitor a entender de forma mais clara os objetivos centrais do trabalho. Desta forma, a revisão apresentada se estende na descrição e na discussão de aspectos que transcendem os objetivos deste trabalho de pesquisa.

\subsection{Generalidades}

Solo grampeado é uma técnica empregada para a estabilização e contenção de taludes em corte. $\mathrm{O}$ processo construtivo consiste na introdução de inclusões passivas no maciço a ser estabilizado. Estas inclusões trabalham essencialmente à tração e são aliadas a um revestimento de face, mas podem, em alguns casos, sofrer esforços cisalhantes e momentos fletores.

A terminologia específica para esta técnica ainda não foi totalmente consolidada em língua portuguesa. Os termos solo grampeado e solo pregado são os mais comuns. A denominação de solo pregado se aproxima mais da terminologia internacional (soil nailing em 
inglês e sol clué em francês) e apresenta-se semelhante ao resultado final da sua aplicação, onde as inclusões trabalham de forma semelhante a pregos comuns (DIAS, 1992). Contudo, a maioria dos trabalhos publicados em português utiliza a nomenclatura solo grampeado, sendo esta, portanto, a que será adotada nesta pesquisa.

O solo grampeado é utilizado basicamente em duas situações: na estabilização de taludes com baixa estabilidade e na contenção de taludes em corte (Figura 2.1).

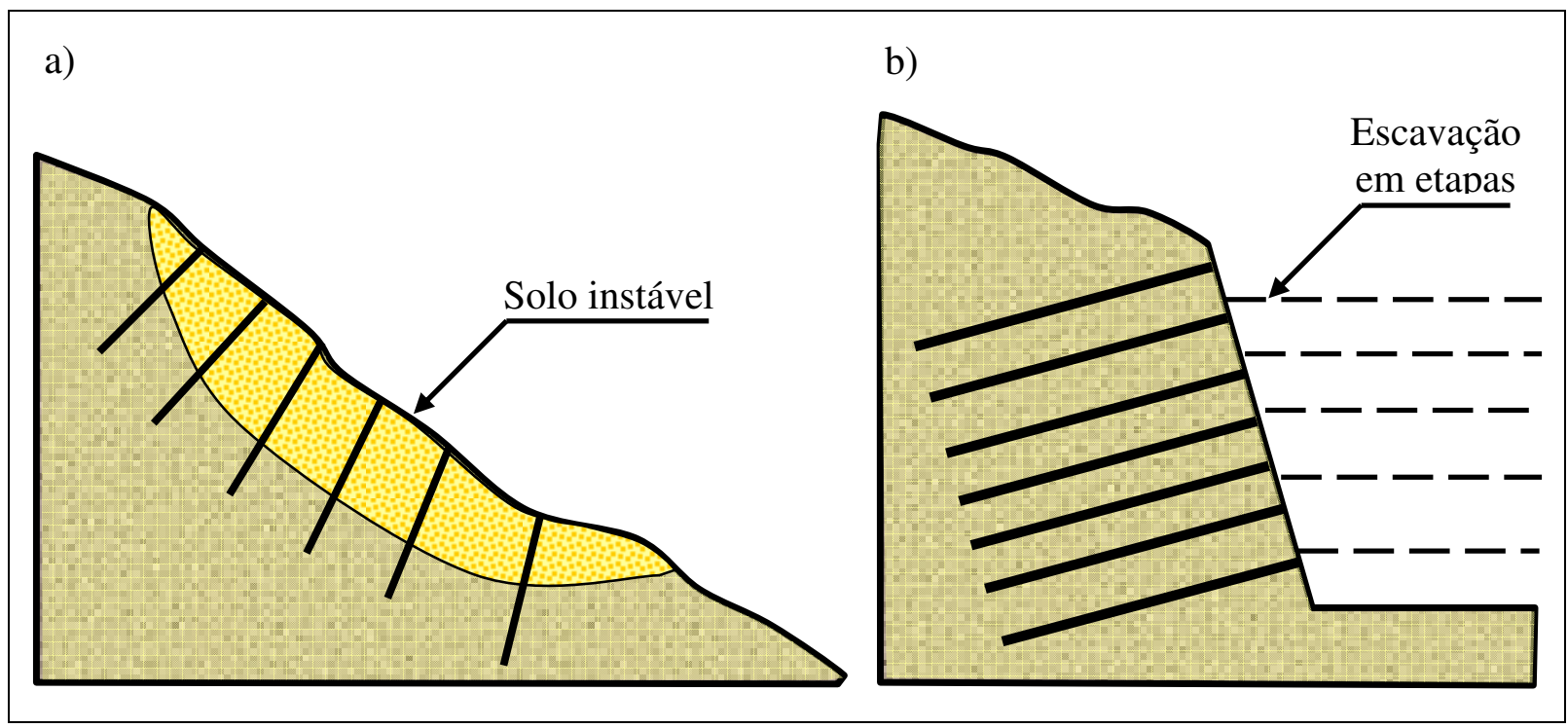

Figura 2.1 - Aplicações mais comuns de solos grampeados: a - estabilização de taludes; b contenção de taldes em corte (adaptado de Guilloux e Schlosser, 1982).

Na estabilização de taludes, a função do reforço é promover um aumento no fator de segurança ou reduzir os deslocamentos. Este tipo de aplicação não exige serviços de escavação e os grampos são, em geral, instalados perpendiculares à superfície potencial de ruptura.

A contenção de taludes em corte, por outro lado, exige escavações (execução do corte), que são feitas em etapas alternadas, com os serviços de instalação dos grampos, implantados horizontal ou sub-horizontalmente, e o revestimento da face. Outra diferença entre as duas aplicações refere-se aos esforços que solicitam o reforço. Na estabilização de taludes são mobilizadas principalmente as resistências ao cisalhamento e a momentos fletores 
dos grampos, enquanto que os principais esforços solicitantes na contenção de taludes em corte são as forças de tração.

As obras em solo grampeado são comumente utilizadas em caráter definitivo, contudo, também podem ser executadas em estruturas temporárias. A definição da vida útil da obra e do potencial corrosivo do solo são os principais fatores que intervêm na definição de formas de prevenção da corrosão dos grampos.

\subsubsection{Histórico}

A origem da técnica de solo grampeado está em geral associada à construção de túneis com o processo NATM ("New Austrian Tunneling Method”) (BRUCE; JEWELL, 1986; GUILLOUX; SCHLOSSER, 1982; JURAN; ELIAS, 1991; ORTIGÃO; PALMEIRA; ZIRLIS, 1995). Neste método, o reforço do maciço rochoso é feito com a introdução de inclusões (barras de aço envoltas em calda de cimento) imediatamente após cada fase de escavação da galeria, resultando numa apreciável redução na espessura do revestimento (Figura 2.2). A metodologia seguiu sendo aplicada em rochas menos competentes até a sua utilização em solos, substituindo grandes escoramentos de madeira por chumbadores e concreto projetado.

A origem do solo grampeado pode ser também associada a técnica da terra armada, apresentando-se como um método de reforço complementar para esta técnica. A terra armada consiste basicamente na introdução de fitas de aço em um maciço compactado. Estes elementos são adicionados entre as camadas compactadas de solo à medida que o aterro é executado. O solo grampeado, por sua vez, foi concebido para estabilizar taludes em corte e, similarmente à terra armada, os grampos são implantados em um maciço de solo com um 
padrão geométrico regular. Em ambos os métodos os espaçamentos (horizontal e vertical) e um comprimento das inclusões que forneça fatores de segurança adequados são definidos a partir de parâmetros geométricos da obra e de características do solo.

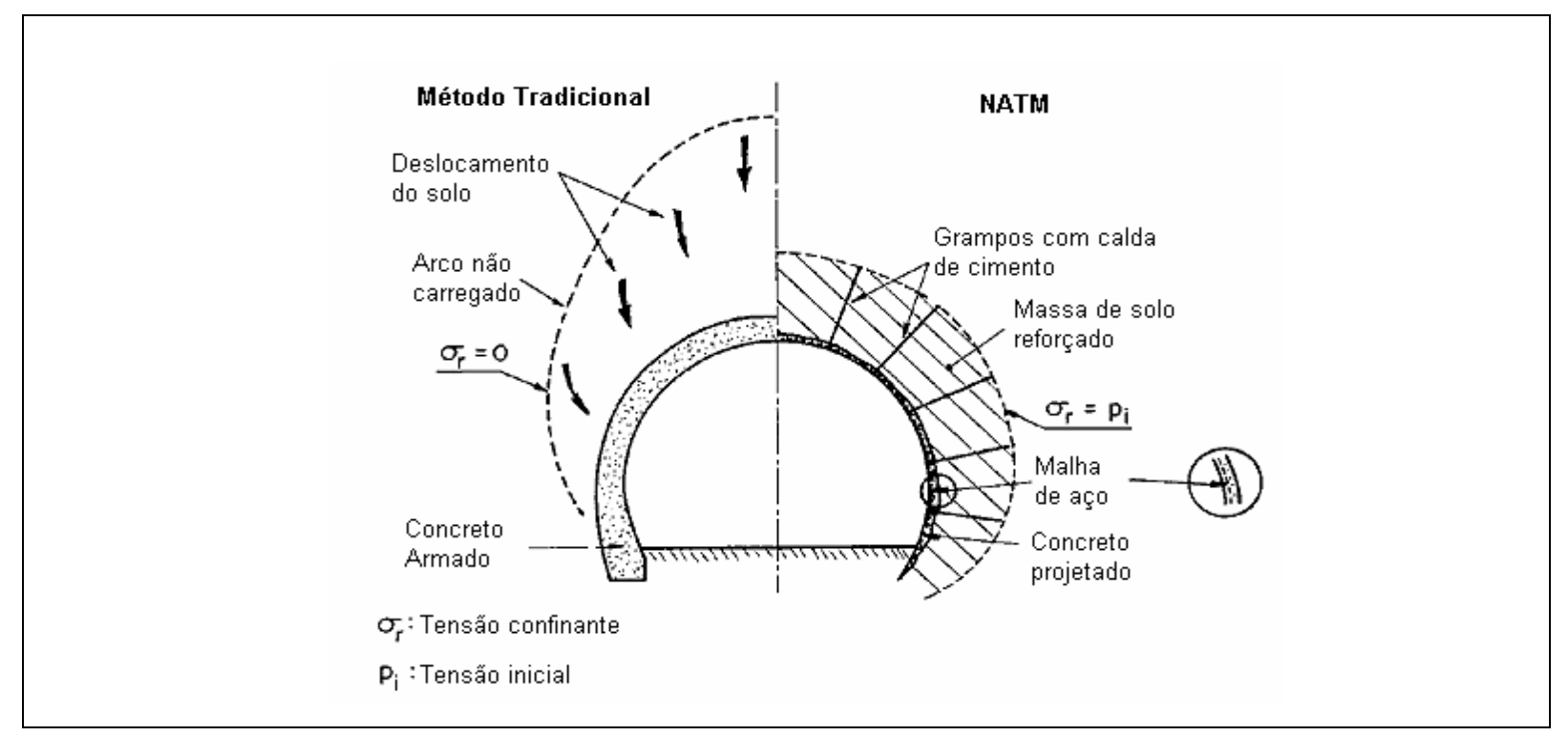

Figura 2.2 - Métodos de execução de túneis (adaptado de FRENCH NATIONAL RESEARCH PROJECT CLOUTERRE, 1991).

A primeira obra documentada em solo grampeado foi executada na França, em 1972 e 1973, em um talude ferroviário próximo à cidade de Versailles. Trata-se de uma contenção temporária construída em areia (Fontainebleau sand) com alta densidade de grampos curtos (Figura 2.3). Ortigão, Palmeira e Zirlis (1995) citam que, no Brasil, a primeira obra em solos grampeados foi executada em 1970.

Um grande desenvolvimento da técnica de solo grampeado pautou-se em um estudo de quatro anos executado na Alemanha Ocidental a partir de 1975. Este estudo envolveu a iniciativa privada, a Universidade de Karlsruhe e o governo alemão. Os resultados foram analisados e descritos por Stocker, Gudehus e Gassler (1979). 


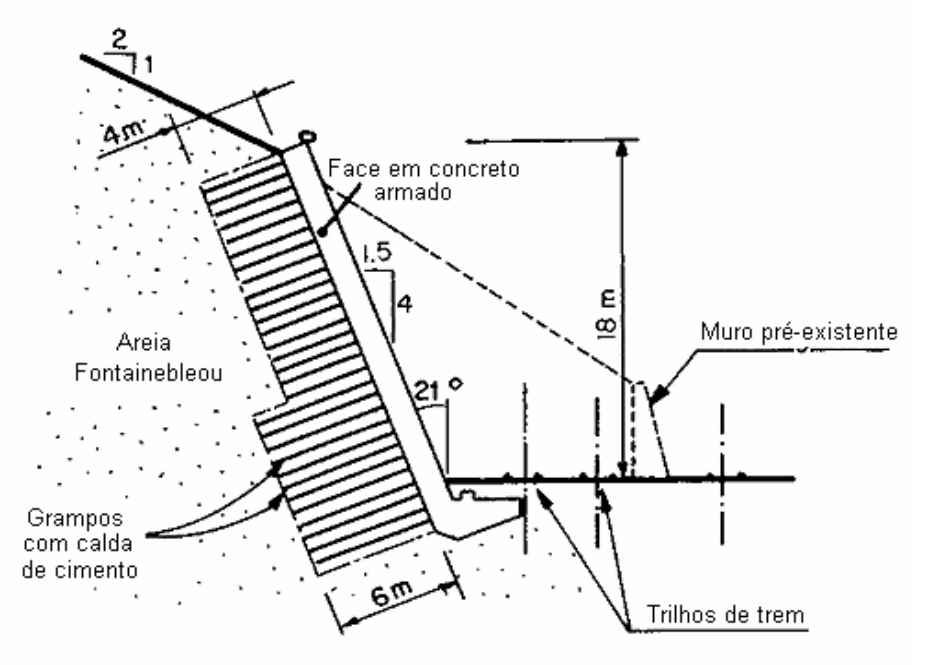

Figura 2.3 - Primeiro muro em solo grampeado documentado, em Versailles, França (adaptado de FRENCH NATIONAL RESEARCH PROJECT CLOUTERRE, 1991).

O emprego pioneiro de solo grampeado nos Estados Unidos ocorreu em 1976, nas escavações para a construção do Hospital Good Samaritan, na cidade de Portland. O desenvolvimento da técnica foi acelerado por um extenso programa de pesquisa executado pela Universidade da Califórnia. Neste programa, foram executados ensaios em modelos, utilização de centrífuga e análises por elementos finitos. Shen et al. (1981) citam que uma série de obras de contenção em solo grampeado foram executadas no Canadá com escavações da ordem de $18 \mathrm{~m}$ antes de 1976.

Em 1979 aconteceu o primeiro simpósio sobre solos grampeados. Este permitiu uma valiosa troca de experiências entre os engenheiros dos diversos países, pois, até então, a técnica havia se consolidado de forma isolada, principalmente na França, na Alemanha Ocidental e nos Estados Unidos.

Em 1981 foi realizada a primeira tentativa de industrialização da técnica de solo grampeado com o desenvolvimento de uma face pré-fabricada (LOUIS, 1981 apud FRENCH NATIONAL RESEARCH PROJECT CLOUTERRE, 1991). 
Em 1982 foi executada uma escavação para as fundações do escritório central de uma indústria, em Pittsburgh, Estados Unidos (NICHOLSON, 1986 apud FRENCH NATIONAL RESEARCH PROJECT CLOUTERRE, 1991). O fato relevante desta obra é a associação do solo grampeado com um pré-jateamento da face, utilizando-se concreto, e o reforço com microestacas de algumas fundações críticas na zona grampeada.

Em 1986 teve início um grande projeto de pesquisa francês sobre solos grampeados, o Projeto CLOUTERRE, com a participação da iniciativa privada e do governo francês. O objetivo deste programa era promover o uso do solo grampeado através de recomendações, incrementando o conhecimento do comportamento e para o desenvolvimento de projetos com este tipo de estrutura. O projeto abrangeu estudos experimentais com murosmodelo além da análise de dados dos ensaios realizados pelas empresas participantes e resultou na produção de um volume com diversas recomendações em 1991.

No Brasil, como apresentado anteriormente, a primeira obra em solo grampeado foi executada em 1970, de forma intuitiva, para a estabilização do emboque do túnel de adução do sistema Cantareiras. A partir de 1972, chumbadores perfurados e injetados com calda de cimento ou somente cravados foram utilizados nos túneis e taludes da Rodovia dos Imigrantes. Pitta, Souza e Zirlis (2003) citam que foram executados $72.763 \mathrm{~m}^{2}$ de obras de solo grampeado no país de 1983 a 2003, dos quais cerca de 60\% entre 1996 e 2003, demonstrando a rápida expansão na utilização desta técnica no Brasil.

\subsubsection{Seqüência executiva}

O sistema de contenção em solo grampeado é realizado em etapas sucessivas e descendentes, com escavações, como representado na Figura 2.4 


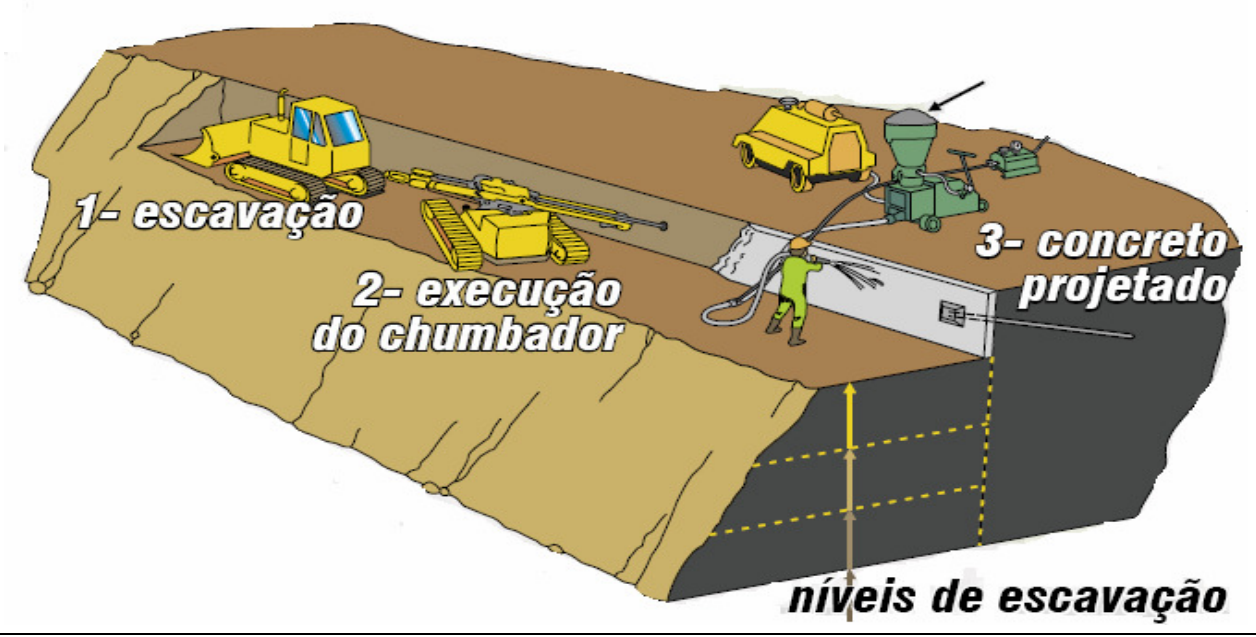

Figura 2.4 - Etapas executivas da técnica de solos grampeados (SOLOTRAT ENGENHARIA GEOTÉCNICA, 2003).

\subsubsection{Escavação}

A primeira etapa na seqüência executiva dos solos grampeados é a escavação, que é realizada em estágios, comumente com profundidades de 1 a 2 m. Alguns autores relatam profundidades diferentes de escavação como Vucetic, Tufenkjian e Doroudian (1993) que sugerem entre 1,2 a 1,8 m e Raju, Wong e Low (1997) e Gässler e Gudehus (1981), de 1 a 1,5 m.

O material a ser escavado deve permanecer estável por algumas horas até a aplicação dos grampos e o revestimento da face. No caso de areias finas isso pode ser possível devido aos efeitos da capilaridade. Argilas muito moles devem apresentar uma resistência mínima não drenada de $15 \mathrm{kPa}$ para permaneceram estáveis (ORTIGÃO; PALMEIRA; ZIRLIS, 1995).

O umedecimento de solos não coesivos secos, o pré-jateamento da face recémescavada com concreto projetado e ainda a escavação em trechos horizontais intercalados (em slots) são recomendações úteis para se executar obras sem sobressaltos em solos de 
comportamento geotécnico difícil.

\subsubsection{Instalação dos grampos}

Os grampos devem ser instalados no solo imediatamente após a escavação. Existem diversas formas de instalação, as mais comuns são a cravação e a perfuração seguida de aplicação de calda de cimento.

\subsection{Grampos cravados}

Os grampos podem ser cravados no maciço de solo usando-se martelos pneumáticos ou hidráulicos, sem nenhuma escavação preliminar. A instalação é rápida, econômica e particularmente eficiente em solos não coesivos fofos. O método oferece resistência imediata uma vez que não é necessário esperar nenhum tempo de cura da calda de cimento.

Este método apresenta a desvantagem de ser aplicado apenas a grampos curtos, em geral até $3 \mathrm{~m}$ de comprimento, não excedendo $8 \mathrm{~m}$. Esta restrição se deve principalmente ao espaço necessário para os equipamentos de instalação. É inadequado a solos muito rígidos ou que contenham blocos de rocha e em obras permanentes, devido à dificuldade em protegêlos contra corrosão. O atrito desenvolvido entre o solo e o grampo apresenta valores da ordem de 30 a $40 \mathrm{kPa}$ em areias e valores ainda menores em argilas.

\subsection{Grampos envoltos em calda de cimento}

Este é o tipo de instalação mais comum (ORTIGÃO; PALMEIRA; ZIRLIS, 1995). O processo inicia-se com a perfuração do solo, produzindo furos com diâmetro entre 50 e $600 \mathrm{~mm}$. Este procedimento pode ser realizado com trados helicoidais contínuos ou 
perfuratrizes e facilitado com o uso de fluidos como água, ar comprimido ou lama bentonítica. Após a perfuração são realizadas a instalação e fixação das inclusões, normalmente formadas por barras de aço, com ou sem proteção contra corrosão, ou ainda de fibras de vidro e outros materiais similares. É comum a utilização de barras de aço de 13 a 32 mm de diâmetro. Devem ser utilizados centralizadores para garantir a continuidade e a regularidade do recobrimento com o material de preenchimento (grout) do furo, aplicada após a fixação das inclusões.

O grout pode ser aplicado sob pressão ou por gravidade. Podem ser utilizadas calda de cimento ou resinas. Normalmente a calda de cimento, com elevado teor de cimento, é aplicada em solos e as resinas em materiais rochosos e em locais de difícil acesso (ZIRLIS; PITTA, 1992). Barras corrugadas são utilizadas para aumentar a aderência com a calda de cimento. Este procedimento resulta numa resistência de interface (grampo-solo) da ordem de $100 \mathrm{kPa}$ para a maioria dos tipos de solo.

O contato entre os grampos e a face é comumente feito por porca e parafuso, para barras com diâmetro igual ou maior que $20 \mathrm{~mm}$, ou com a dobra da barra, caso esta possua diâmetro menor que 20 mm (Figura 2.5).

A grande vantagem desta forma de instalação dos grampos é o seu campo de atuação, sendo aplicável em praticamente qualquer tipo de solo. Além disso, existe a possibilidade de sempre se obter a resistência ao arrancamento necessária através da injeção sob pressão controlada.

Dentre as desvantagens destaca-se a necessidade de adaptar o equipamento de perfuração quando as características do solo variam, à medida que as escavações prosseguem. Essa situação pode tornar a obra mais complicada e menos econômica. Adiciona-se a isso o fato de que a resistência do grampos será plenamente disponível quando o processo de cura 
for concluído. Este tipo de inclusão deve ser executado com uma inclinação mínima de $10^{\circ}$ em relação à horizontal. Esta medida visa facilitar o preenchimento do furo com a calda de cimento.

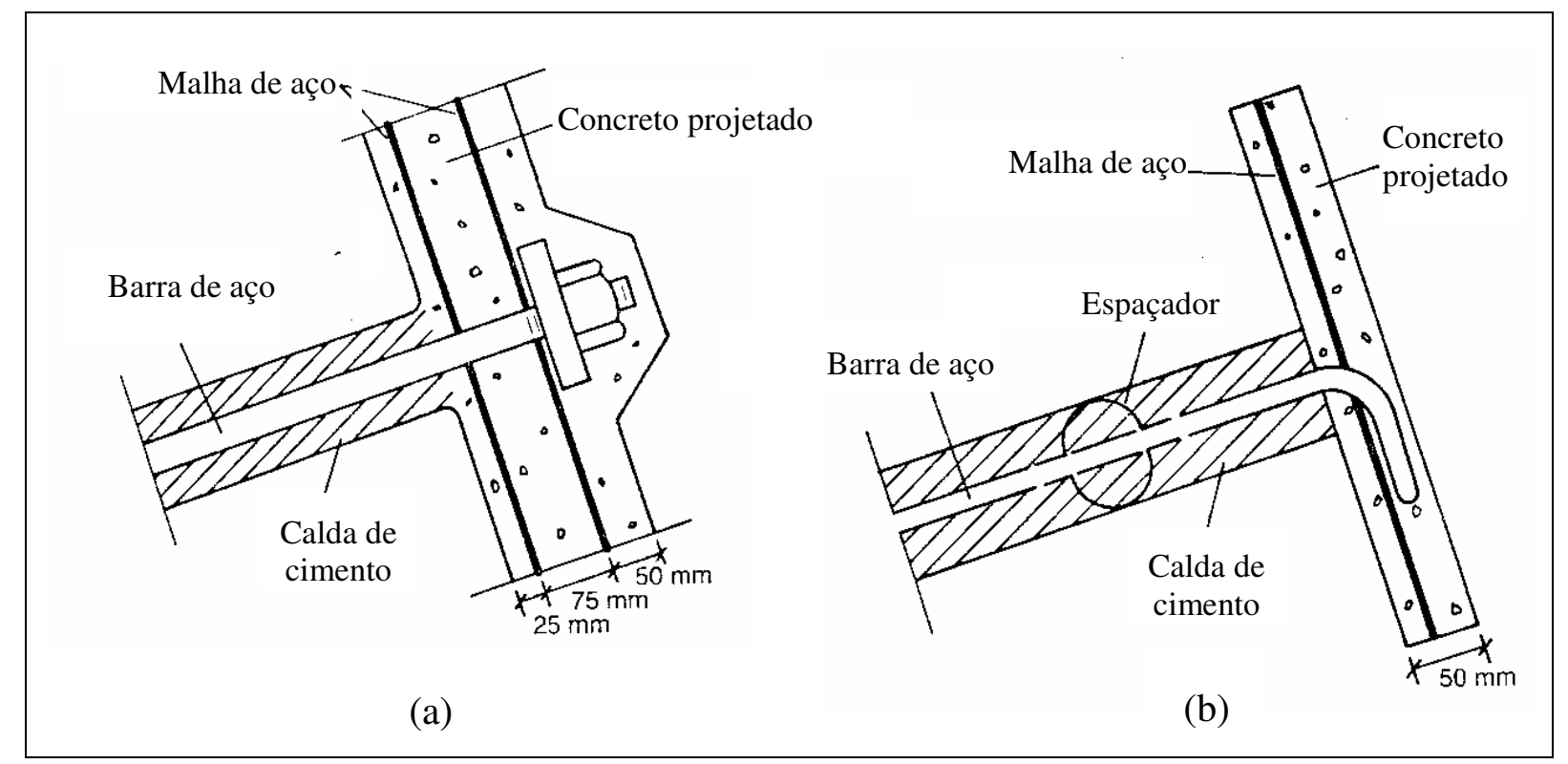

Figura 2.5 - Tipos de ligações grampo-face. (a) Para barra com mais de $20 \mathrm{~mm}$ de diâmetro e (b) para barras com menos de $20 \mathrm{~mm}$ de diâmetro (adaptado de Ortigão, Palmeira e Zirlis, 1995).

\subsection{Outros tipos de grampos}

Outros métodos de instalação dos grampos são citados na literatura, mas são pouco utilizados no Brasil. Juran e Elias (1991) citam os grampos instalados com jet-grouting (jet-grouted nails). A técnica consiste na cravação por vibropercussão e na injeção da calda de cimento através de um canal longitudinal de poucos milímetros sob altas pressões (4 a 20 MPa). Essa pressão é suficiente para causar o fraturamento hidráulico do solo circundante, criando um maciço único composto por solo e calda de cimento. Esse processo produz um aumento na resistência ao arrancamento dos grampos.

A técnica "Hurpinoise" de instalação dos grampos foi desenvolvida na França e consiste na cravação de cantoneiras de aço no solo por penetração dinâmica, inclinadas em 
$20^{\circ}$ com a horizontal. O comprimento das inclusões é curto e a densidade é alta (dois grampos por metro quadrado) (GUILLOUX; SCHLOSSER, 1982).

Outro método de instalação recente é o lançamento de uma barra metálica diretamente no solo. Este procedimento consiste na utilização de um lançador de ar comprimido que atira o grampo diretamente no terreno, chegando a velocidades de $320 \mathrm{~km} / \mathrm{h}$ e energia de até $100 \mathrm{~kJ}$. É uma técnica rápida e que reduz procedimentos além de proporcionar as menores perturbações no solo. Esta tecnologia foi inicialmente utilizada na estabilização de taludes, mas já tem uso em contenções (INGOLD; MYLES, 1996; MYLES; BRIDLE, 1992).

\subsection{Proteção dos grampos contra a corrosão}

Os grampos necessitam de proteção contra a corrosão quando instalados em ambientes agressivos. Como não existe uma norma específica para a técnica de solos grampeados, recomenda-se adotar a proposta da norma NBR 5629 - Execução de Tirantes Ancorados no Terreno (ORTIGÃO; PALMEIRA; ZIRLIS, 1995). Esta norma traz a classificação para determinar o tipo de proteção a ser utilizada em cortinas atirantadas (Tabela 2.1).

\subsubsection{Revestimento de face}

O revestimento da face é feito, em geral, com concreto projetado armado com malha de aço eletrossoldada. Embora não possua função estrutural, pois absorve apenas pequenos carregamentos, a face deve evitar rupturas localizadas e processos erosivos.

O concreto projetado pode ser aplicado por via seca ou úmida. A aplicação por via seca é mais utilizada devido a sua praticidade, pois é possível interromper e reiniciar os 
serviços sem perdas de material e tempo para limpeza do equipamento (ZIRLIS; PITTA, 1992). A aplicação por via úmida é mais apropriada para trabalhos maiores devido ao tamanho dos equipamentos necessários. A elevada energia de aplicação produz uma boa compactação do concreto, o que aumenta a resistência final do revestimento. É preciso atentar para o efeito sombra. Esse efeito é provocado pela má distribuição do concreto projetado atrás da malha de aço caso o lançamento não previna a sua ocorrência e pode gerar regiões com concreto projetado menos compactado.

Tabela 2.1 - Definição do tipo de proteção contra corrosão a ser utilizada em cortinas atirantadas e aplicada aos solos grampeados.

\begin{tabular}{ccc}
\hline Classe & Tipo de Grampo & Proteção \\
\hline 1 & $\begin{array}{c}\text { Permanentes em ambientes agressivos ou } \\
\text { temporários em ambientes muito agressivos }\end{array}$ & $\begin{array}{c}\text { Dupla, com uso de pintura } \\
\text { anticorrosiva e calda de } \\
\text { cimento }\end{array}$ \\
2 & $\begin{array}{c}\text { Permanentes em ambientes não agressivos ou } \\
\text { temporários em ambientes medianamente } \\
\text { agressivos }\end{array}$ & $\begin{array}{c}\text { Simples, com calda de } \\
\text { cimento injetado }\end{array}$ \\
& Temporários em ambientes não agressivos & $\begin{array}{c}\text { Simples, com calda de } \\
\text { cimento injetado }\end{array}$ \\
\hline
\end{tabular}

A espessura do revestimento varia entre 50 e $150 \mathrm{~mm}$, com uma ou duas malhas de aço embutidas no concreto projetado. Faces mais esbeltas podem ser utilizadas em superfícies inclinadas enquanto que as contenções permanentes e verticais possuem faces com espessura maior.

A malha pode ser substituída por fibras de aço ou fibras sintéticas misturadas ao concreto projetado. Esta opção tem a vantagem de reduzir o tempo de execução e o volume de concreto (Figura 2.6). Mesmo com um custo mais elevado, a economia do produto final pode chegar a valores de 20 a $40 \%$ por metro quadrado aplicado. 


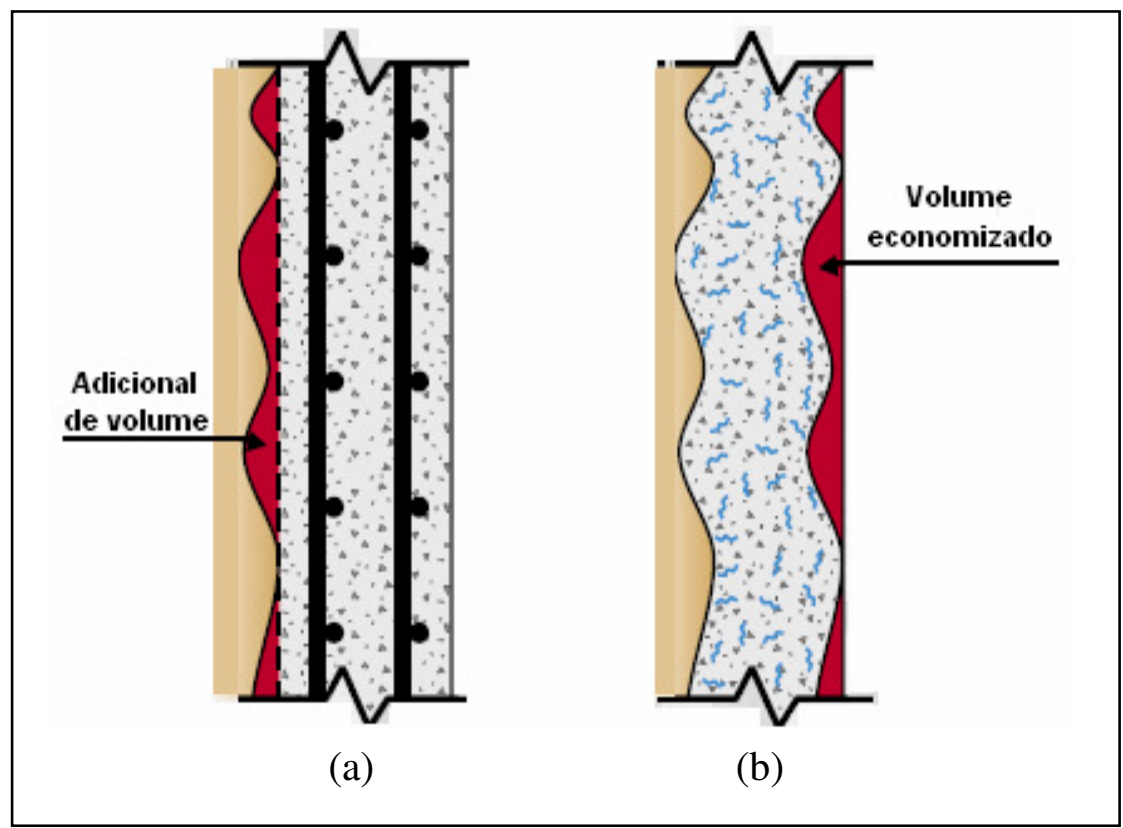

Figura 2.6 - Comparação entre face em concreto projetado com malha de aço eletrossoldada (a) e concreto com fibras (b) (SOLOTRAT ENGENHARIA GEOTÉCNICA, 2003).

A face também pode ser revestida com concreto lançado quando não existem problemas de instabilidade em curto prazo. Esse método é usual quando uma grande quantidade de reforço é utilizada ou quando a face tem que se apresentar com concreto liso.

Outro tipo de face empregado por Saramago et al. (2005) consiste no uso de blocos pré-moldados de cimento. Os autores alegam que o uso de blocos pré-moldados incorpora uma vantagem estética à obra, pois permite a execução de faces arquitetonicamente mais elaboradas.

\subsubsection{Drenagem}

Uma regra geral para a execução de solos grampeados é que o terreno deve estar acima do nível d'água ou ainda que este deve ser rebaixado antecipadamente. Contudo, mesmo tomando estas medidas, é necessário evitar que a percolação de água de outras fontes, como a chuva ou vazamentos em tubulações, ocorra na direção do paramento. 
A proteção consiste basicamente na execução de drenos profundos e de aparatos para drenagem superficial. Devem ser utilizados também drenos de paramento com a função de promover a drenagem das águas vindas do talude, que chegam ao paramento.

A drenagem profunda é feita com drenos subhorizontais profundos. Estes consistem de tubos plásticos ranhurados (diâmetro em torno de $50 \mathrm{~mm}$ ), inseridos em furos no solo de aproximadamente $75 \mathrm{~mm}$ de diâmetro. Os tubos são recobertos por geotêxtil ou tela de nylon com a função de filtração. Os comprimentos dos drenos variam entre 6 e 18 m. (Figura 2.7).

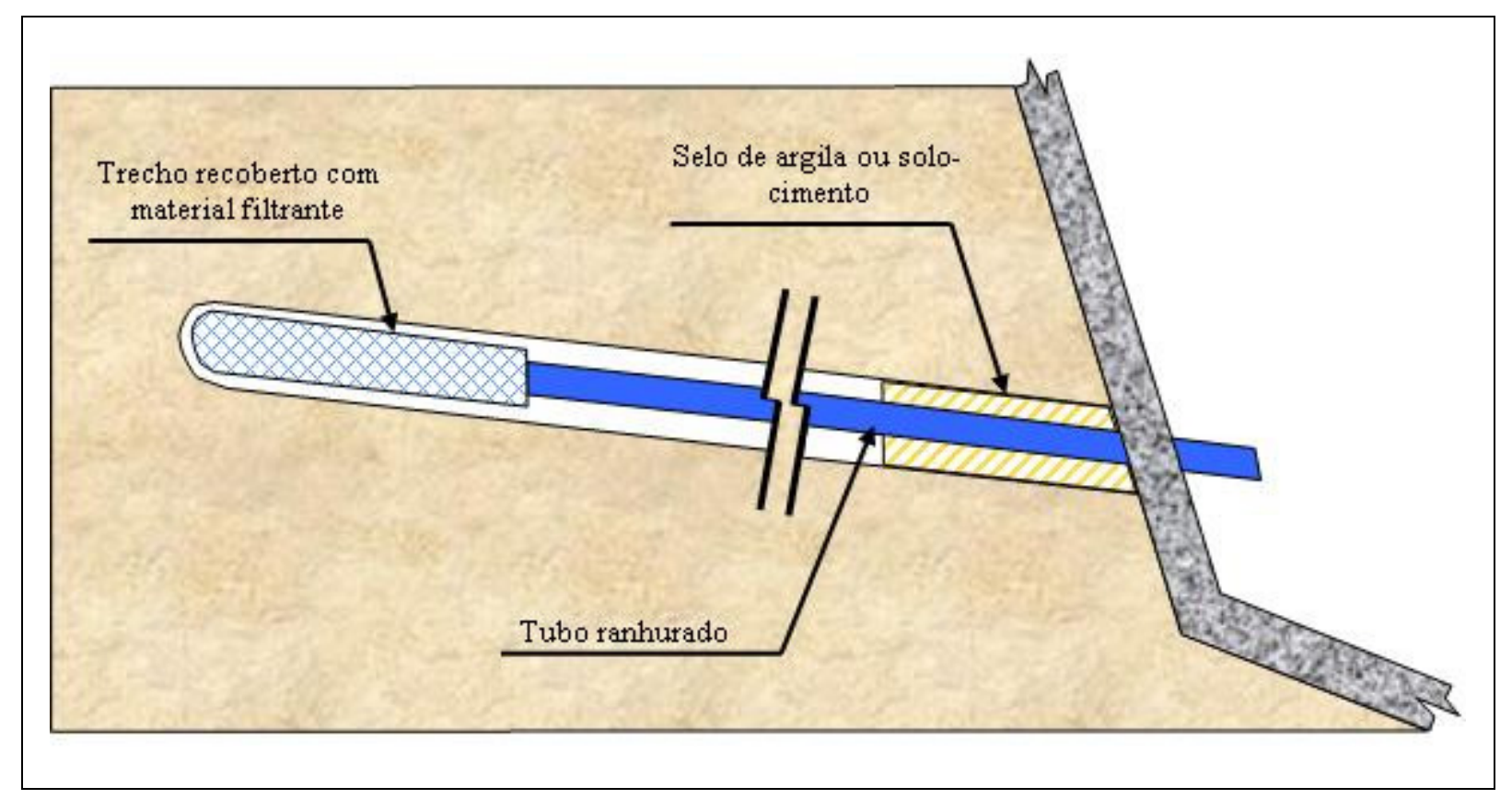

Figura 2.7 - Esquema de dreno subhorizontal profundo (SOLOTRAT ENGENHARIA GEOTÉCNICA, 2003).

A drenagem de paramento é feita com barbacãs ou com dreno linear contínuo. Os barbacãs são executados com a escavação de uma cavidade (aproximadamente 0,2 x 0,2 x 0,2 m) preenchida com material arenoso. Nessa cavidade é instalada uma saída com tubo drenante, partindo do seu interior para fora do revestimento, com inclinação descendente. É um procedimento de drenagem pontual que deve ser projetado para abranger toda a superfície 
do paramento, respeitando espaçamentos especificados em projeto.

A drenagem do paramento também pode ser feita com drenos lineares contínuos. Estes são construídos com a instalação de uma calha envolta com material filtrante, geotêxtil ou geodreno. Este dreno se estende na vertical do paramento, desde sua crista até o pé do talude, onde aflora na canaleta de pé.

Por fim, é necessário atentar para a drenagem superficial. Canaletas de crista e de pé cumprem este papel. Em geral são moldadas no local e cobertas com concreto projetado.

Com estas medidas, a água é conduzida corretamente por toda a obra e é importante que elas sejam instaladas antes da execução do revestimento da face. Ressalta-se a necessidade de uma correta manutenção do sistema de drenagem. Trincas, sujeiras e obstruções em tubos devem ser evitadas.

\subsubsection{Vantagens da técnica de solo grampeado}

Dentre as vantagens do solo grampeado comparado com outras técnicas de reforço do solo verifica-se o uso reduzido de equipamentos, caracterizados ainda por serem de pequeno porte. Isto implica em menores níveis de ruído e vibração, além de facilitar a execução em locais remotos e em áreas de difícil acesso. Além desta, cita-se também como vantagem a sequiência construtiva, que permite que serviços diferentes (escavação, instalação dos grampos e revestimento de face) sejam realizados simultaneamente. Portanto, com o devido planejamento logístico da obra, é possível atingir uma alta velocidade de execução.

A técnica de solo grampeado permite que alterações do projeto inicial sejam realizadas juntamente com o andamento da obra. O espaçamento entre grampos, a profundidade de escavação e o comprimento dos grampos são exemplos de parâmetros que 
podem ser modificados ao longo da execução da obra. Isso permite uma grande flexibilidade da técnica de solo grampeado, que também é associada a sua aplicabilidade em locais e geometrias onde outras técnicas apresentariam problemas para serem empregadas (execução em superfícies inclinadas, em curvas ou com bermas). Azambuja, Strauss e Silveira (2001) citam a flexibilidade como uma das grandes vantagens da técnica de solo grampeado.

Finalmente, a execução de solo grampeado em faces inclinadas possibilita um aumento na estabilidade global e redução das perdas de material no revestimento de face.

A combinação de equipamentos de pequeno porte, velocidade e simplicidade da técnica torna o solo grampeado uma opção de baixo custo em obras de reforço de solos. Bruce e Jewell (1986) citam que é possível obter uma economia de 10\% a 30\% em contenções da ordem de 10 m executadas em solo grampeado.

\subsubsection{Limitações da técnica de solo grampeado}

Naturalmente, o sistema de contenção em solo grampeado apresenta algumas limitações para a sua aplicação. Os deslocamentos horizontais e verticais são inerentes à aplicação da técnica. Deve-se, portanto, avaliar a magnitude desses deslocamentos e verificar os danos que possam ocorrer a estruturas vizinhas. Tais deslocamentos devem ser previstos e controlados através de um projeto adequado de execução e monitoramento da obra.

A técnica de solo grampeado é recomendada apenas em escavações em solos acima do nível d'água ou com o prévio rebaixamento do mesmo. Escavações abaixo do nível d'água podem dificultar a execução do revestimento de face e ainda causar instabilidades localizadas.

Feijó e Ehrlich (2005) afirmam que a técnica de solos grampeados é bastante 
competitiva em solos residuais não saturados devido as suas boas características mecânicas. Contudo, alguns tipos de solos não são apropriados para o grampeamento. É necessário que o solo seja auto-portante por algumas horas, período entre a escavação e a aplicação do revestimento de face. Caso os solos não apresentem capacidade de suporte, pode-se executar um pré-tratamento com grout para estabilizar a face. Esta medida aumenta os custos e a complicação da obra, tornando-a inviável em alguns casos. Ortigao, Palmeira e Zirlis (1995) relatam a tentativa de executar uma contenção em solo grampeado nas areias fofas da praia de Copacabana, Rio de Janeiro. A escavação de $1 \mathrm{~m}$ não foi possível e, mesmo após umedecimento e jateamento com concreto projetado, ainda houve a ruptura da face. Neste caso foi necessária a adoção de outra técnica de contenção.

Alguns exemplos de tipos de solos nos quais a aplicação do grampeamento pode ser inviável são as areias puras e secas, solos com bolsões de água, solos com alto teor de argila, nos quais o teor de umidade pode aumentar após a construção, argilas moles e solos susceptíveis a congelamento. Raju, Wong e Low (1997) utilizaram uma areia fina à média, pouco graduada, nos seus estudos. Contudo, este material apresentou um teor de umidade aceitável para garantir uma estabilidade temporária suficiente para a instalação dos grampos após uma fase de escavação. Guilloux, Notte e Gonin (1983) verificaram o comportamento de uma obra em solo grampeado durante o inverno nos Alpes franceses. O congelamento ocorreu apenas no solo adjacente à face, levando a um incremento nos esforços de tração e nos deslocamentos dos grampos. Contudo, estes esforços não levaram à ruptura da obra, pois foram absorvidos pela parte do grampo que estava inserido no trecho de solo que não congelou. 


\subsubsection{Comparação com outras técnicas}

A técnica de solo grampeado apresenta-se como uma alternativa para obras de contenção de encostas e estabilização de taludes. Neste item, o solo grampeado é comparado a duas outras técnicas de contenção de encostas, a cortina atirantada e a terra armada. Estes sistemas de contenção foram escolhidos para comparação devido as suas similaridades, mas com o objetivo de destacar também o que difere entre eles.

\subsubsection{Comparação com cortinas atirantadas}

Os tirantes convencionais utilizados para estabilização de taludes ou escavações apresentam grandes semelhanças com a técnica de solo grampeado. Contudo, existem diferenças marcantes que são preponderantes na escolha de um método ou outro para uma determinada situação (Figura 2.8).

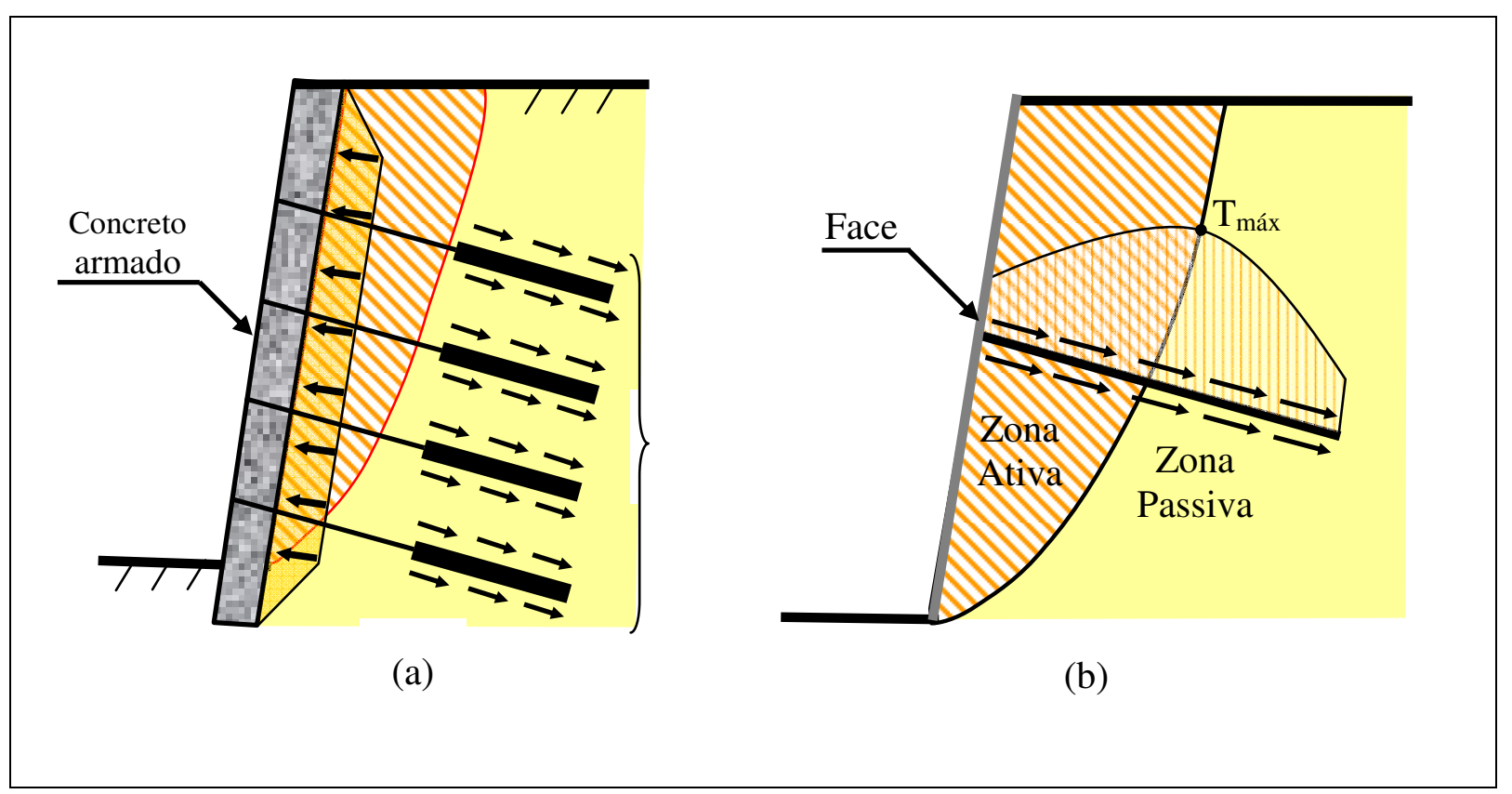

Figura 2.8 - Comparação entre cortinas atirantadas (a) e solo grampeado (b) (adaptado de Ortigão, Palmeira e Zirlis, 1995). 
Os tirantes são intervenções ativas, enquanto que os grampos possuem um trabalho inicial passivo. Isso ocorre porque os tirantes são protendidos com cargas de 150 a 1000 kN (ORTIGÃO; PALMEIRA; ZIRLIS, 1995) quando a contenção está pronta. Esta protensão garante que não ocorram deslocamentos da face. Os grampos, por sua vez, não são protendidos. Em alguns casos são aplicadas cargas de 5 a $10 \mathrm{kN}$ para garantir o contato entre a face e o solo contido (ORTIGÃO; PALMEIRA; ZIRLIS, 1995; BRUCE; JEWELL, 1986). Os deslocamentos são necessários para que haja mobilização da resistência ao cisalhamento da interface entre o solo e o grampo.

Os tirantes possuem um comprimento livre. Nos grampos, o contato solo-grampo se dá ao longo de toda a sua extensão. Como conseqüência disso, a distribuição de tensões no solo é diferente nos dois casos. Nas cortinas atirantadas, os esforços de tração são constantes ao longo de todo o comprimento livre. Nos solos grampeados, a força de tração varia ao longo de todo o comprimento do reforço.

Contenções em solo grampeado apresentam uma densidade de inclusões superior à encontrada nas cortinas atirantadas. Como conseqüência disso, a ruptura de um grampo não é tão severa quanto a ruptura de um tirante. Zirlis e Pitta (1992) citam que a ruptura de um tirante pode induzir a um acréscimo de carga de $65 \%$ nas ancoragens adjacentes.

As altas cargas aplicadas nos tirantes levam à consideração dos esforços de puncionamento no dimensionamento da face. A face de concreto nos solos grampeados não possui função estrutural, funcionando apenas para prevenir instabilidades localizadas. A face de concreto em cortinas atirantadas possui espessura da ordem de 0,2 a 0,3 m (ORTIGÃO; PALMEIRA; ZIRLIS, 1995) enquanto que, nos solos grampeados, este parâmetro apresentase em torno de $0,15 \mathrm{~m}$.

No projeto de cortinas atirantadas evitam-se faces inclinadas, pois estas dificultam 
o lançamento do concreto. Nos solos grampeados, a face é executada, em geral, com concreto projetado, que pode ser aplicado em qualquer direção. Com isso é possível aplicar a técnica em taludes pré-existentes, evitando-se gastos extras com escavações.

Os tirantes tendem a ser longos (15 a 45m) e, portanto, necessitam de equipamentos maiores para instalação. O comprimento dos grampos situa-se entre $60 \%$ e $120 \%$ da altura total de escavação.

Ortigão, Palmeira e Zirlis (1995) destacam que a maioria das rupturas de taludes em solos residuais ocorre em pequenas profundidades. A técnica de solos grampeados, aliada a um sistema de drenagem profunda e superficial, é uma solução muito econômica para estes casos. O emprego de cortinas atirantadas é mais recomendável quando a superfície potencial de ruptura é mais profunda.

\subsubsection{Comparação com terra armada}

As duas técnicas possuem vários pontos em comum, contudo apresentam diferenças consideráveis. As semelhanças vão além da aparência física final da obra, perceptível à primeira vista. Em ambas as técnicas, as inclusões são instaladas sem pré-tensão. As forças nos reforços são mobilizadas a partir das deformações do solo contido e os pontos de máxima tração nas inclusões se situam no interior do maciço de solo e não na face. Com a localização geométrica destes pontos é possível separar a massa de solo em duas zonas, uma ativa e outra passiva. As inclusões trabalham basicamente devido ao contato solo-reforço. A zona reforçada é estável e resiste ao empuxo da zona não reforçada como um muro de gravidade.

A face nas duas técnicas não apresenta função estrutural, sendo então de pequena 
espessura. Painéis pré-fabricados são utilizados na terra armada e nos solos grampeados é comum encontrar a face em concreto projetado.

Apesar de apresentarem muitas semelhanças, as duas técnicas apresentam diferenças marcantes. A distinção mais notável reside no método executivo. Por concepção, a terra armada é executada em aterro, onde as camadas são compactadas alternadamente com a disposição das inclusões. Os solos grampeados são executados em corte, onde as inclusões são instaladas à medida que as fases de escavação são concluídas. Isto tem uma influência essencial na distribuição das forças que se desenvolvem nas inclusões e nos deslocamentos da face (Figura 2.9).

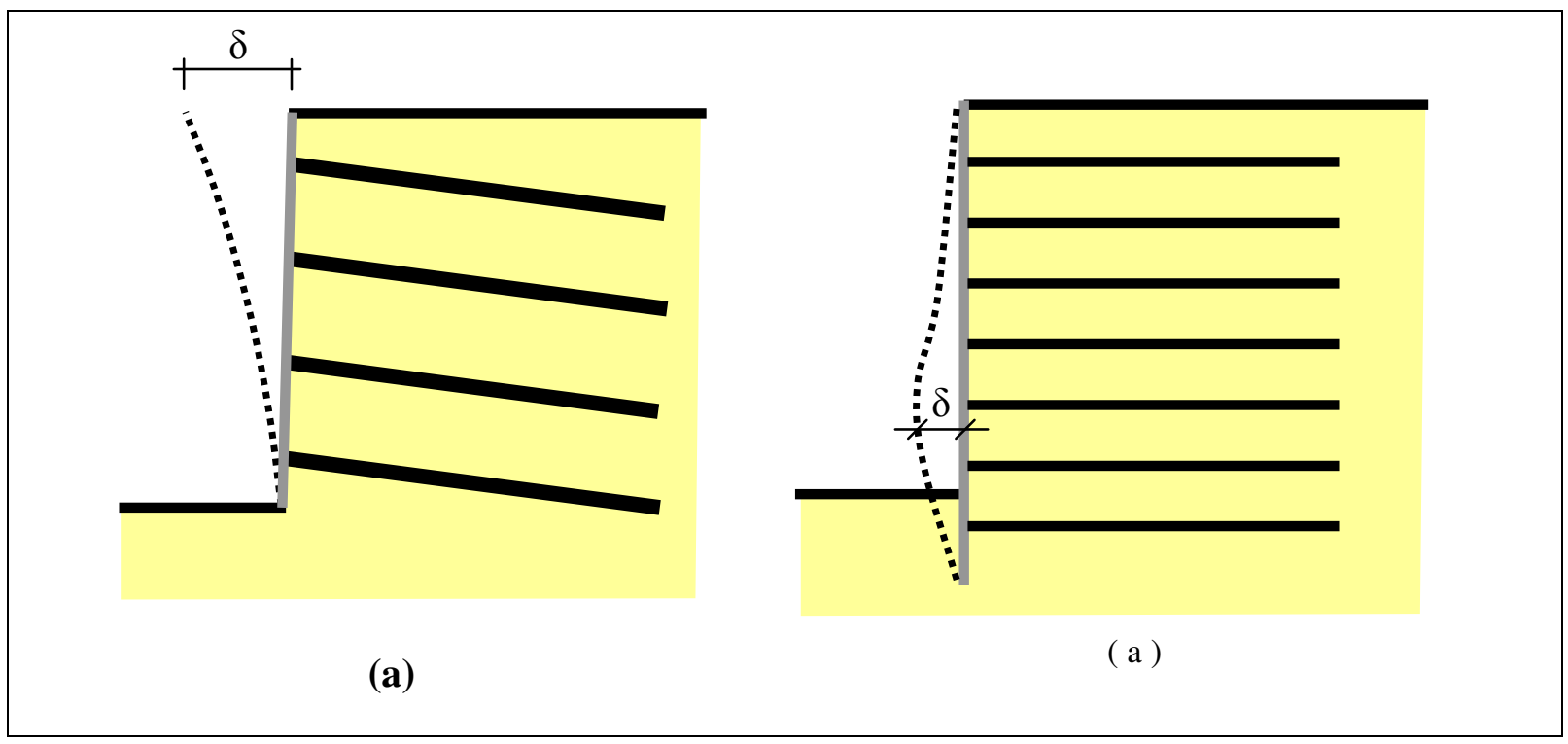

Figura 2.9 - Representação dos pontos de deslocamentos horizontais máximos da face na técnica de solos grampeado (a) e da terra armada (b).

A técnica de solo grampeado explora as condições naturais dos solos adjacentes enquanto que a terra armada, executada em aterro, emprega solos pré-selecionados e com maior controle de disposição devido ao processo de compactação.

Nos solos grampeados, devido ao uso de argamassa de cimento, o contato soloreforço possui uma parcela física e outra química (atrito e adesão, respectivamente). Na terra 
armada, quando se emprega solo granular (solo recomendado), a interação entre o solo e a inclusão se dá basicamente devido ao atrito entre o solo e as inclusões.

Schlosser (1982) destaca ainda que, em solos grampeados, os reforços são capazes de resistir à tração e aos momentos fletores, devido à sua maior rigidez. Pode-se considerar ainda a resistência destes aos esforços cisalhantes, principalmente nos casos onde são aplicados para corrigir taludes pouco estáveis. As inclusões na terra armada resistem apenas aos esforços de tração. Contudo, comumente as obras em solo grampeado não apresentam esforços cisalhantes e momentos fletores nos grampos.

\subsubsection{Estruturas mistas}

Algumas obras combinam a técnica de solo grampeado a outras técnicas de contenção de taludes. Essa opção tem por objetivo reduzir os deslocamentos laterais, prevenir instabilidades, possibilitar a utilização de fases de escavação maiores ou combater problemas de instabilidade devido ao fluxo de água (FRENCH NATIONAL RESEARCH PROJECT CLOUTERRE, 1991).

As maiores deformações nos solos grampeados ocorrem na crista do muro. A redução dos deslocamentos laterais pode ser obtida com a introdução de uma ou duas linha de tirantes na parte superior da contenção. Recomenda-se que a ancoragem seja feita atrás dos limites do muro em solo grampeado.

O "Tervoile" grampeado consiste na execução de tirantes e grampos à medida que a escavação prossegue. A diferença está na face, que compreende estacas pré-fabricadas, montadas a cada face de escavação.

Outra estrutura mista é o "Berlin Wall" associado ao solo grampeado. Nesta 
técnica, estacas são instaladas antes da escavação e são executados os grampos no espaço entre estacas, à medida que a escavação prossegue. As estacas são reforçadas com tirantes que penetram no terreno. Os grampos permitem aumentar a distância entre estacas.

\subsection{Interação solo-grampo}

A interação solo-grampo pode se desenvolver de duas formas diferentes: através da resistência ao cisalhamento de interface entre o solo e o grampo e da tensão de terra lateral grampo (Bridle e Davis, 1997; Schlosser, 1982; Clouterre, 1991). A primeira induz o surgimento de tensões de tração nos grampos. A tensão de terra lateral torna possível a mobilização da resistência dos grampos em relação ao cisalhamento e a momentos fletores.

\subsubsection{Resistência ao cisalhamento da interface entre o solo e o grampo}

O mecanismo de interação mais importante nos solos grampeados, em contenções de escavações, é a mobilização da resistência ao cisalhamento da interface entre o solo e o grampo ao longo das inclusões (SCHLOSSER, 1982; SCHLOSSER E DE BUHAN, 1990). Bruce e Jewell (1986) declaram que o solo grampeado aumenta a resistência ao cisalhamento do solo com os grampos atuando sob tensão de tração. A tensão cisalhante na interface sologrampo é, portanto, o principal parâmetro de projeto.

A mobilização da resistência ao cisalhamento de interface requer deslocamentos relativos entre o solo e o grampo da ordem de alguns milímetros, bem como ocorre em estacas com relação à mobilização do atrito lateral. As deformações internas da massa reforçada induzem a mobilização da resistência ao cisalhamento de interface ao longo dos grampos e o posterior tracionamento dos mesmos. Estas deformações ocorrem devido ao desconfinamento 
do solo à medida que a escavação prossegue.

A resistência ao cisalhamento da interface entre o solo e o grampo sofre influência principalmente do tipo de grampo e do teor de umidade do solo. Os grampos instalados em furos preenchidos com calda de cimento por gravidade apresentam grande variabilidade no atrito de interface. Quanto mais lisas forem as paredes do furo, menores esse valores. A perfuração reduz a tensão normal a zero nas paredes do furo, então, a tensão normal inicial depois da instalação dos grampos é muito baixa. A resistência ao cisalhamento de interface em curto prazo pode ser altamente influenciada pelo grau de saturação do solo caso este possua certa quantidade de finos (FRENCH NATIONAL RESEARCH PROJECT CLOUTERRE, 1991).

\subsubsection{Empuxo lateral de terra}

O empuxo lateral de terra requer certo nível de rigidez dos grampos, bem como uma zona de cisalhamento no solo (SCHLOSSER, 1982). Uma estrutura mais flexível irá se deformar até a obtenção do equilíbrio. Este tipo de interação é mais comum no emprego da técnica de solos grampeados para a estabilização de taludes. Também pode ocorrer em obras de contenção com fator de segurança baixo, sendo menos expressiva que a mobilização da resistência ao cisalhamento da interface entre o solo e o grampo.

No cisalhamento de uma massa de solo grampeado, a ruptura se dá por tração na interseção do grampo com o plano de ruptura ou por plastificação do material nos pontos de máximos momentos fletores (Figura 2.10).

Um estudo realizado por Juran et al. (1981 apud SCHLOSSER, 1982) mostrou uma mobilização progressiva da rigidez à flexão das barras, mas foram necessários 
deslocamentos maiores que aqueles suficientes para mobilizar a resistência ao cisalhamento de interface. Juran et al. (1983) mostraram que são necessários grandes deslocamentos relativos do solo para mobilizar a resistência contra o empuxo lateral de terra. Eles ressaltam que, como conseqüência disso, qualquer aplicação que precise da mobilização da resistência ao cisalhamento dos reforços deve ser projetada com respeito a deslocamentos admissíveis das estruturas circundantes. De forma geral, em condições de serviços, a resistência à flexão dos grampos é mobilizada modestamente.

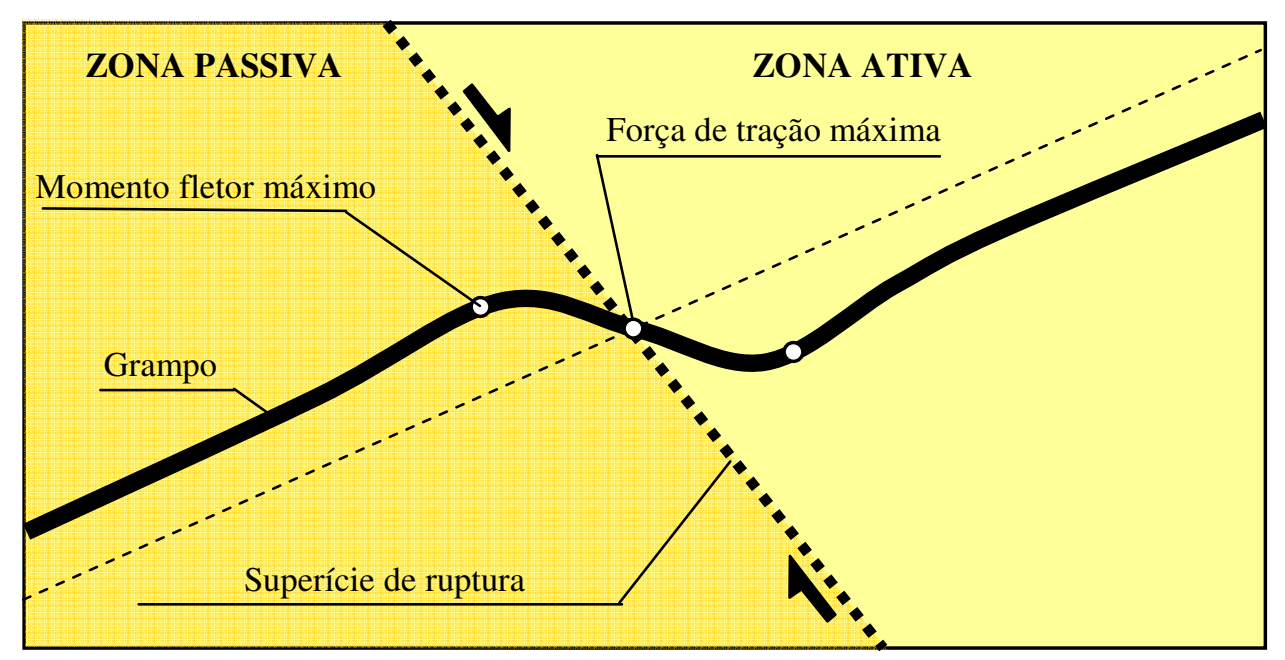

Figura 2.10 - Esquema de deformação de uma barra submetida a cisalhamento ao longo de uma superfície potencial de ruptura (adaptado de Schlosser, 1982).

\subsection{Comportamento da obra}

O comportamento de obras em solo grampeado tem sido objeto de diversos estudos, em obras reais e experimentais, em escalas reduzidas ou não. Os estudos visam verificar o comportamento no tocante aos deslocamentos da face e do solo contido, bem como as tensões aplicadas nos grampos e no solo. 


\subsubsection{Deslocamentos e tensões de tração}

O modo como as tensões e os deslocamentos se distribuem no solo e nos grampos se deve basicamente ao método construtivo do solo grampeado. À medida que as escavações são executadas, o solo contido sofre um desconfinamento. Ao final da construção, o muro apresenta uma leve inclinação da face. Os deslocamentos do solo são inevitáveis e necessários, uma vez que a mobilização do atrito e da adesão entre o solo e o grampo requer alguma deformação do solo (GUILOUX; SCHLOSSER, 1982). Os deslocamentos da face dependem de vários parâmetros tais como o fator de segurança global, a razão entre o comprimento dos grampos e a altura da contenção $(\mathrm{L} / \mathrm{H})$, a velocidade de construção, a altura dos estágios de escavação, o espaçamento entre grampos e sua rigidez e a capacidade de carga do solo de fundação.

Os valores máximos de deslocamento horizontais e verticais ocorrem na crista da face, com predomínio daqueles na direção horizontal. O deslocamento horizontal máximo encontra-se comumente entre 0,1 e 0,4\% da altura da contenção (CARTIER e GIGAN, 1983; CLOUTERRE, 1991), valores suficientes para ativar o solo, pois deslocamentos horizontais da ordem de $0,1 \%$ da altura do anteparo são suficientes para levar o maciço de solo ao estado ativo. Apesar de poderem ser determinados empiricamente (GÄSSLER; GUDEHUS, 1981; SHEN; BANG; HERRMAN, 1981), os deslocamentos horizontais máximos são difíceis de prever devido ao elevado número de fatores que podem influenciar neste valor. Azambuja et al (2003) relatam deslocamentos máximos da ordem de $0,7 \%$ da altura da contenção. Bruce e Jewell (1986) apresentam um levantamento de diversas obras em solo grampeado. Estes autores relatam valores de deslocamento horizontal máximo entre $0,08 \%$ e $0,30 \%$ da altura total da obra de contenção. 
Alguns autores encontraram deformações da crista do muro fora dessa ordem de grandeza. Raju, Wong e Low (1997), por exemplo, estudaram o comportamento de seis muros experimentais em solo grampeado, construídos com baixos fatores de segurança para levá-los a ruptura por ação de uma sobrecarga aplicada. Neste estudo, os autores encontraram deformações da crista da ordem de $2 \%$ da altura da obra no final da fase de escavação. Eles atestam que tais deslocamentos ocorreram devido aos baixos fatores de segurança inerentes ao projeto do muro.

O instante em que as tensões de tração são aplicadas aos grampos é também inerente ao método construtivo. O tracionamento em uma linha de grampos situados à mesma altura começa apenas quando as escavações estão em níveis mais baixos. O projeto CLOUTERRE (1991) apresenta uma contenção em solo grampeado de caráter experimental onde o tracionamento é quase que totalmente imposto aos grampos até o terceiro ou quarto nível de escavação seguinte. A partir desse nível os acréscimos de tensões são mínimos (Figura 2.11). Com isso pode-se concluir que os grampos situados próximos ao pé do muro são os menos solicitados.

Springer, Gerscovich e Sayão (2001) estudaram a influência do tipo de ligação entre os grampos e a face na deformabilidade da obra. Eles mostraram que pode haver puncionamento nos grampos embutidos ou dobrados podendo, portanto, ser considerados livres. Nos grampos fixados por placa metálica e porca é mais adequado considerá-los ligados à face. Através de simulações computacionais baseadas no método de diferenças finitas eles concluiram que os deslocamentos da massa de solo dependem da razão $\mathrm{L} / \mathrm{H}$, sendo L é o comprimento dos grampos e H é a posição vertical do grampo em relação ao pé do talude. Para $\mathrm{L} / \mathrm{H}<0,67$, os deslocamentos horizontais e verticais são menores em grampos fixados à parede. Para os demais valores de L/H o método construtivo não apresentou influência. 


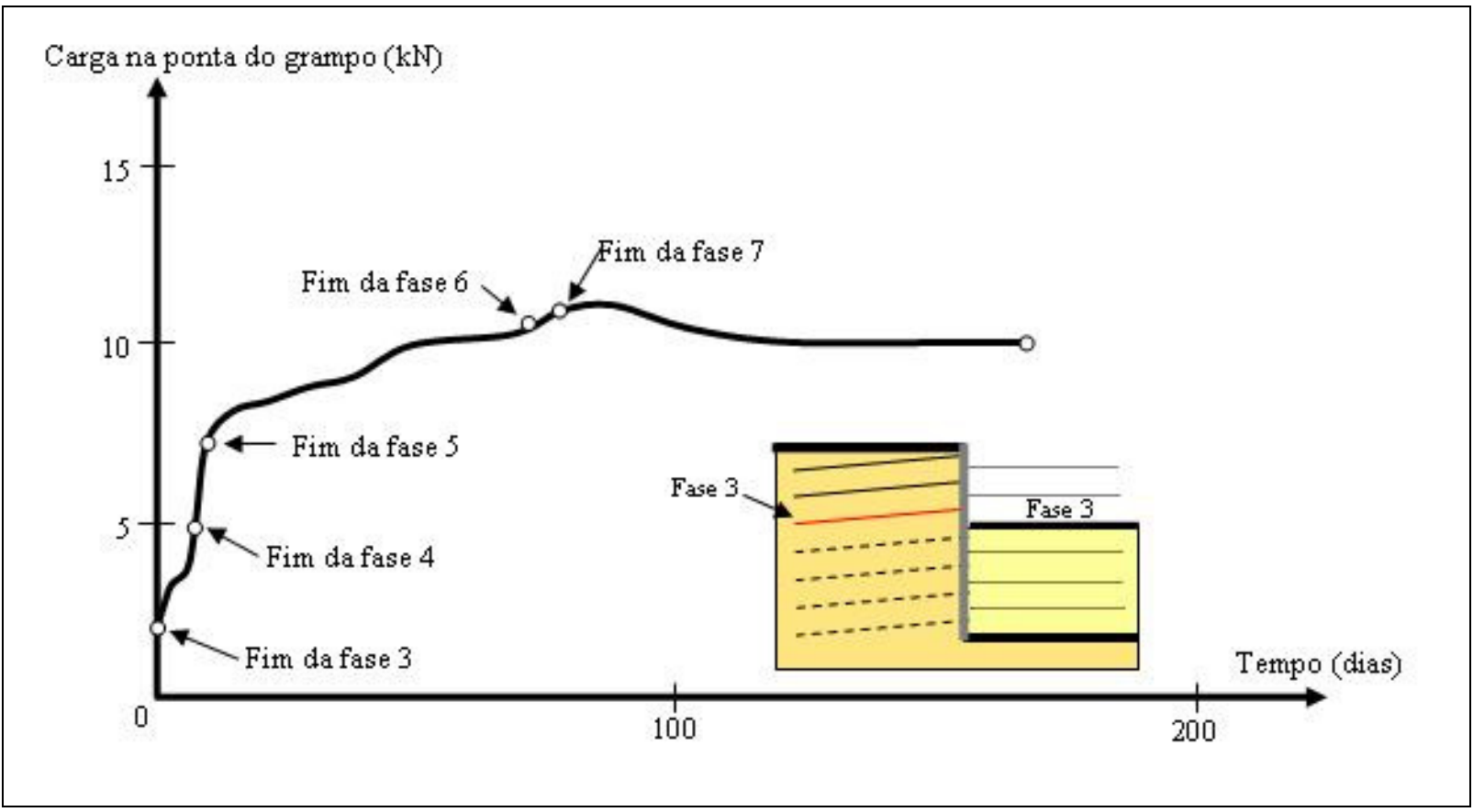

Figura 2.11 - Carregamento progressivo de um grampo em solo grampeado devido ao processo de escavação (FRENCH NATIONAL RESEARCH PROJECT CLOUTERRE, 1991).

\subsubsection{Força máxima de tração mobilizada}

As tensões máximas de tração nos solos grampeados se encontram no interior da massa de solo reforçada, como em muitas outras técnicas de reforço de solos onde a transmissão dos esforços se dá ao longo de toda extensão das inclusões (FRENCH NATIONAL RESEARCH PROJECT CLOUTERRE, 1991). A máxima tração ocorre na interseção dos grampos com a superfície potencial de ruptura (linha imaginária que une os pontos de máxima tração nos reforços) e serve de referência para definir, em projeto, a quantidade de reforços para evitar a ruptura da obra. A superfície potencial de ruptura separa o solo em duas zonas, uma ativa e outra passiva (Figura 2.12). Esta linha é normalmente curva, tendo um trecho praticamente vertical na parte superior e se localiza a cerca de $0,3 \mathrm{H}$ da face, sendo H a altura total de escavação, no caso de uma contenção vertical e com superfícies de jusante e montante horizontais. A inclinação da face e a presença de taludes acima da 
contenção alteram essa distância.

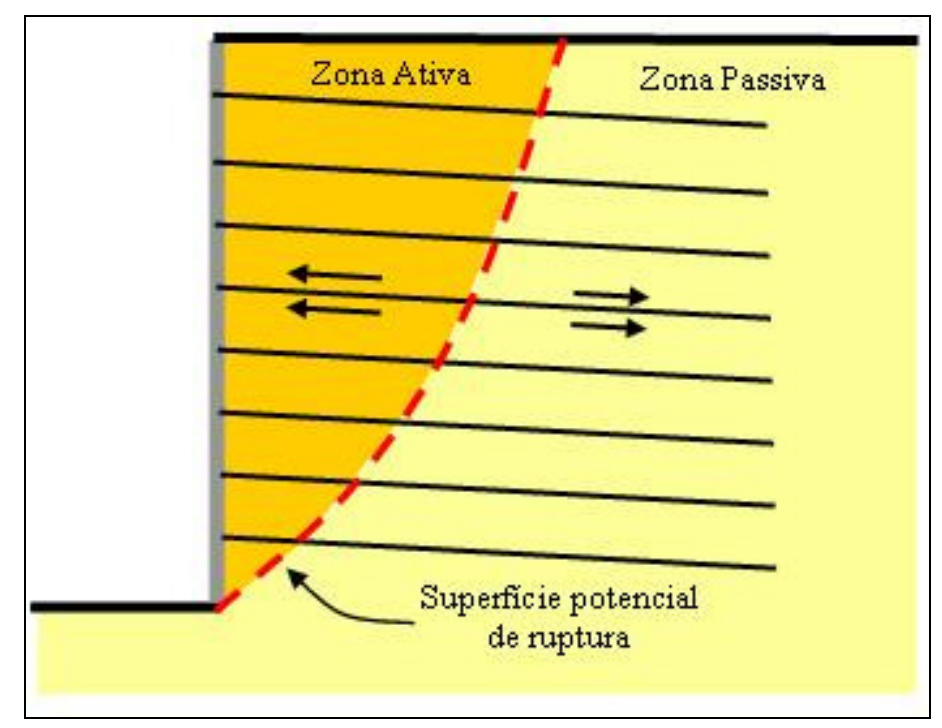

Figura 2.12 - Zonas ativa e passiva características de contenções em solo grampeado (EHRLICH; SILVA; 1992).

A localização do ponto da tensão de tração máxima é fundamental para calcular o comprimento de ancoragem necessário para que não ocorra o arrancamento do grampo. Raju, Wong e Low (1997) apresentam um estudo do comportamento de solos grampeados em escala reduzida. Utilizaram grampos com 1,6 m de comprimento em contenções de $3 \mathrm{~m}$ de largura e 3,25 $\mathrm{m}$ de profundidade. Os grampos foram instrumentados com strain gages. A força nos grampos apresentou valores máximos próximos à face do modelo.

Em solo reforçado admite-se que haja uma perfeita compatibilidade de deslocamentos entre solo e reforço. Portanto, admitindo-se este princípio em condições de serviço, as deformações dos grampos são as mesmas dos solos na interface entre os dois materiais (EHRLICH, 2003). Então as deformações do solo são controladas pela rigidez dos grampos e se pode definir um Índice de Rigidez Relativa dos grampos $\left(\mathrm{S}_{\mathrm{i}}\right)$ como:

$$
S_{i}=\frac{A_{r} E_{r}}{k P_{a} S_{v} S_{h}}
$$


Onde: $\mathrm{A}_{\mathrm{r}}$ é a área da seção transversal dos grampos, $\mathrm{E}_{\mathrm{r}}$ é módulo de deformabilidade dos grampos, $\mathrm{k}$ é o módulo tangente inicial, $\mathrm{P}_{\mathrm{a}}$ é a pressão atmosférica, $\mathrm{S}_{\mathrm{v}} \mathrm{e}$ $\mathrm{S}_{\mathrm{h}}$ são os espaçamentos vertical e horizontal, respectivamente.

A Figura 2.13 apresenta o modelo tensão-deformação que rege o comportamento solo-grampo (EHRLICH, 2003). A partir desta figura percebe-se que as tensões no solo diminuem à medida que as deformações ocorrem, tendendo ao estado ativo, enquanto que as tensões nos reforços aumentam. As deformações cessam quando o equilíbrio é atingido. Verificando na Figura 2.13, grampos mais rígidos, representados pela reta $\left(\mathrm{S}_{\mathrm{i}}\right)_{2}$ resultam em menores deformações e em tensões no solo e no reforço mais próximas àquelas no repouso. Ao contrário, grampos mais flexíveis $\left(\mathrm{S}_{\mathrm{i}}\right)_{1}$ permitem maiores deslocamentos, suficientes para a plastificação da zona potencialmente instável, resultando em tensões mais próximas do estado ativo. Nestas condições, as tensões no grampo se apresentam mais baixas (EHRLICH, 2003).

\subsubsection{Tensões no solo}

Com o conhecimento das tensões de tração máximas nos grampos é possível estimar o estado de tensões no solo, ao longo da linha de trações máximas, através da seguinte fórmula:

$$
\mathrm{K}=\frac{\mathrm{T}_{\text {máx }} \cos \theta}{\gamma \mathrm{ZS}_{\mathrm{v}} \mathrm{S}_{\mathrm{h}}}
$$

Onde: $\mathrm{T}_{\text {máx }}$ é a força de tração máxima no grampo, $\theta$ é a inclinação dos grampos com a horizontal, $\gamma$ é o peso específico do solo, $Z$ é a profundidade considerada e $S_{\mathrm{v}}$ e $S_{\mathrm{h}}$ são os espaçamentos vertical e horizontal, respectivamente. 


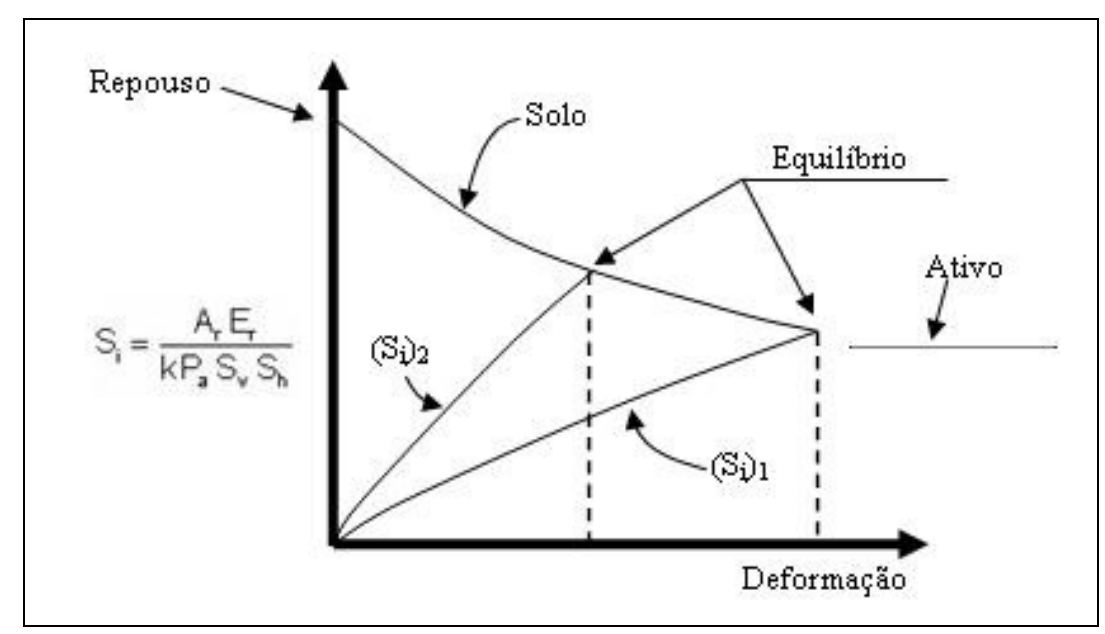

Figura 2.13 - Influência da rigidez do grampo nas deformações e tensões mobilizadas (EHRLICH, 2003, adaptado de Jewell, 1990).

Esta fórmula exprime uma comparação entre as trações máximas e o empuxo ativo sobre a face, caso os grampos fossem removidos. $\mathrm{K}$ situa-se próximo de $\mathrm{K}_{0}$ (coeficiente de empuxo no repouso) na parte superior do muro e se torna menor que $\mathrm{K}_{\mathrm{a}}$ (coeficiente de empuxo ativo) na parte inferior (Figura 2.14). Este comportamento se deve ao método construtivo em escavações sucessivas que mobiliza o arqueamento entre o topo do muro e a base daquele nível de escavação.

\subsubsection{Tipos de ruptura}

Uma estrutura de solo grampeado comporta-se como um bloco monolítico. É feita, portanto, uma distinção entre rupturas internas e externas e ainda uma ação combinada destes dois tipos, a ruptura mista (Figura 2.15). 


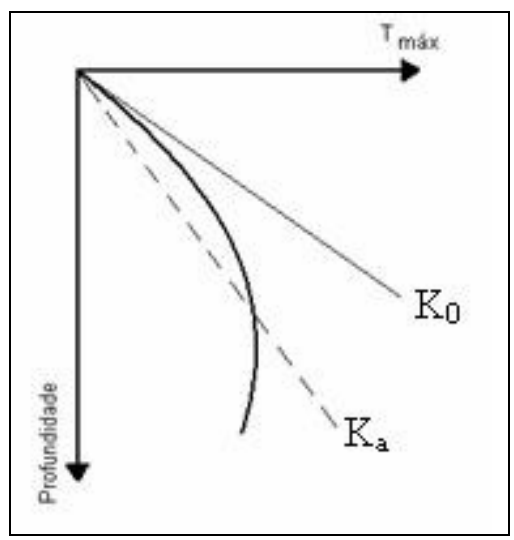

Figura 2.14 - Variação do coeficiente de empuxo com a profundidade em solos grampeados (adaptado de Guilloux e Schlosser, 1982).

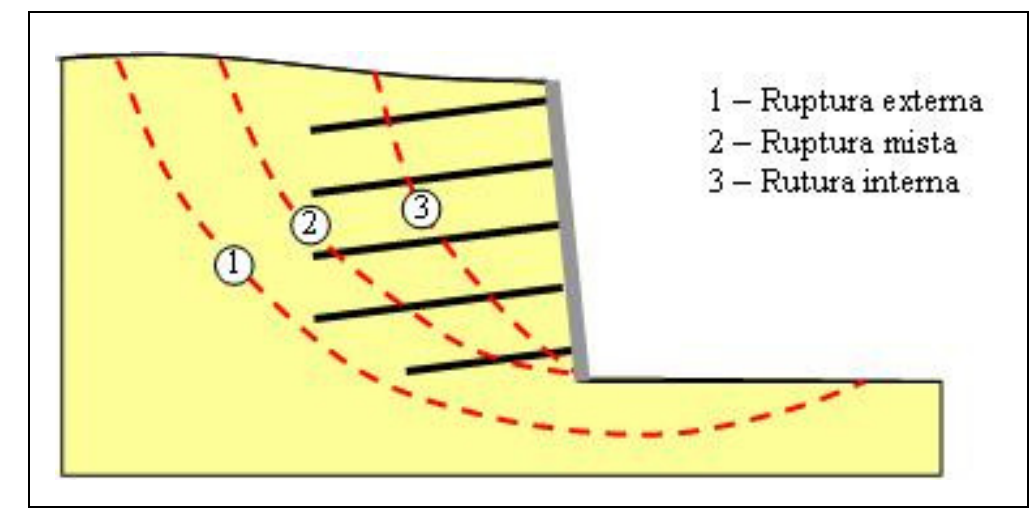

Figura 2.15 - Mecanismos de ruptura em solos grampeados (adaptado de FRENCH NATIONAL RESEARCH PROJECT CLOUTERRE, 1991).

\subsubsection{Ruptura interna}

A ruptura interna pode ocorrer por quatro processos diferentes: ruptura dos grampos, falta de aderência, altura de escavação excessiva ou erosão regressiva (piping).

\subsection{Ruptura dos grampos}

A ruptura dos grampos pode ocorrer devido a uma estimativa incorreta da sua seção transversal, projetando-a com um diâmetro menor que o necessário para suportar os 
esforços. A corrosão das barras também pode gerar essa situação.

A aplicação de uma sobrecarga no topo do muro para a qual ele não foi projetado também pode levar a ruptura dos grampos. Stocker et al. (1979 apud FRENCH NATIONAL RESEARCH PROJECT CLOUTERRE, 1991) executou um experimento que apresentou este tipo de ruptura, que ocorreu de forma repentina e com a superfície correspondendo bem à linha de trações máximas. Kim et al. (1995) investigaram os efeitos da sobrecarga no mecanismo de ruptura em modelos de solos grampeados, em escala reduzida, para obras novas ou de reabilitação. Dentre as conclusões obtidas podem-se destacar o incremento nos deslocamentos da face e que a ruptura dos grampos no muro com sobrecarga ocorre em pontos muito próximos daqueles obtidos com grampos flexíveis sem sobrecarga.

A presença de lentes de gelo em solos susceptíveis ao congelamento pode acarretar também o rompimento dos grampos. Este fenômeno induz aumentos de tensão nos grampos, na região próxima à face. Guilloux, Notte e Gonin (1983) relatam incrementos nas tensões e nos deslocamentos de grampos sujeitos a um inverno rigoroso nos Alpes Franceses. Eles verificaram que o solo atrás da face apresentava temperatura igual a $-5^{\circ} \mathrm{C}$ e que valores positivos de temperatura só eram obtidos a cerca de $0,4 \mathrm{~m}$ da face.

\subsection{Falta de aderência}

A ruptura por falta de aderência é mais comum que aquela por ruptura dos grampos. É a consequiência de uma má estimativa da resistência ao cisalhamento de interface ou por falhas executivas. Este tipo de ruptura se caracteriza pelo comprimento insuficiente do grampo dentro da zona passiva, incapaz de balancear as trações máximas. Os grampos são, portanto, arrancados do solo. Em geral, grandes deformações se desenvolvem antes da ruptura, exceto em alguns casos durante a construção. Schlosser et al. (1992) descrevem uma obra experimental, conduzida pelo Programa CLOUTERRE (1991), onde os grampos têm o 
comprimento reduzido, depois de inseridos no terreno por meio de tubos telescópicos.

A falta de aderência pode ocorrer principalmente por dois motivos: por efeito da saturação em solos com maior teor de finos, ou durante a construção, se o comprimento dos grampos no topo da escavação for insuficiente, especialmente em casos de uma má estimativa da resistência ao cisalhamento de interface.

Guilloux e Schlosser (1982) relatam a ruptura da contenção conhecida como "Les Eparris". Não havia dados de instrumentação desta obra, mas ela é um exemplo da importância da boa estimativa da resistência ao cisalhamento entre o solo e o reforço. Não foram executados ensaios in situ para a obtenção da resistência ao cisalhamento de interface, que foi determinado a partir de análises teóricas e adotado entre 16 kN/m e 70 kN/m. Durante um período de chuvas intensas, ocorreu a ruptura do muro. Executaram-se ensaios de arrancamento nas inclusões após a ruptura, resultando em valores em torno de $15 \mathrm{kN} / \mathrm{m}$. O cálculo do fator de segurança com atrito de interface unitário encontrado resultou em valores iguais a 1,0. A solução encontrada foi reconstruir o muro com inclusões duas vezes mais compridas.

\subsection{Altura de escavação excessiva}

A altura excessiva de escavação pode levar a uma ruptura repentina através de uma instabilidade local que se propaga até o topo da contenção. Neste tipo de ruptura, o solo atrás da face flui devido à eliminação do efeito do arqueamento. A face então desce até encontrar o solo de fundação e os grampos se deformam por flexão, mas não se rompem. Para prevenir este tipo de ruptura, a escavação deve ser mantida em alturas inferiores à altura crítica ou realizadas em aberturas (slots).

O projeto CLOUTERRE (1991) apresenta o resultado de uma ruptura por altura de escavação excessiva realizado em um muro experimental. O muro foi executado com 
incrementos na altura de escavação. Durante a última fase de escavação ( $3 \mathrm{~m}$ de altura) a eficiência do arqueamento foi destruída e houve ruptura local, que se propagou até a superfície.

\subsection{Erosão regressiva (piping)}

Este tipo de ruptura é similar ao anterior na forma como ocorre, contudo, possui causas diferentes. Ocorre em geral devido à presença de fluxo de água no solo. Assim, durante a escavação, as forças de percolação que surgem podem arrastar as partículas do solo através de seus vazios, empobrecendo-o granulometricamente e reduzindo a sua estabilidade local na zona escavada. Rupturas rápidas e regressivas provocam o fluxo do solo atrás do muro. A ruptura por piping resulta da heterogeneidade do solo e de falta de sistemas de drenagem durante a construção.

\subsubsection{Ruptura Externa}

A ruptura externa em solos grampeados ocorre geralmente por escorregamento ao longo da superfície de ruptura, afetando toda a estrutura e atingindo regiões além das

fundações. É comum em obras de contenção e ocorre devido à baixa qualidade do solo de fundação ou por comprimento insuficiente dos grampos.

\subsubsection{Ruptura mista}

A ruptura mista combina instabilidades interna e externa da obra. Refere-se a uma superfície de ruptura que passa por dentro e por fora da zona reforçada e ocorre, geralmente, devido ao comprimento insuficiente dos grampos associado a alguma deficiência destes 
(baixa resistência ou baixo atrito de interface).

\subsection{Monitoramento da obra}

Os solos grampeados necessitam de pequenos deslocamentos para que haja a mobilização efetiva da resistência dos grampos. Assim, o desempenho da obra deve ser acompanhado atentamente através do monitoramento dos deslocamentos da face e do solo contido. As tensões nos grampos e o desempenho da face e do sistema de drenagem também devem ser acompanhados, além da verificação dos níveis piezométricos. Algumas inspeções são obrigatórias e outras são recomendadas para casos específicos. O projeto CLOUTERRE (1991) cita que o monitoramento é especialmente importante para obras com mais de $10 \mathrm{~m}$, em locais com taludes a montante e sensíveis às movimentações. Em nível de projeto, devem ser especificados os responsáveis pelo monitoramento, quais inspeções serão realizadas e com que frequiência, os limites previstos e máximos das medições tomadas e as atitudes necessárias caso estes valores sejam ultrapassados.

\subsubsection{Deslocamentos da face}

Os deslocamentos da face devem ser acompanhados durante a construção e a vida útil da obra. Normalmente as leituras são realizadas com extensômetros analógicos ou digitais ou por leituras com equipamentos topográficos.

\subsubsection{Deslocamentos do solo contido}

O monitoramento dos deslocamentos da massa de solo contido é recomendado 
para dois casos diferentes: em locais com taludes instáveis e quando a obra ou construções vizinhas são sensíveis às movimentações do solo. É realizado normalmente com o auxílio de inclinômetros. As medições devem ser realizadas até profundidades onde nenhum movimento ocorra (FRENCH NATIONAL RESEARCH PROJECT CLOUTERRE, 1991).

\subsubsection{Força nos grampos}

A força nos grampos pode ser acompanhada através da instalação de strain gages. Alguns estudos apresentam grampos em forma de tubos para permitir a instalação de strain gages no interior dos mesmos e evitar a interferência do solo nas suas leituras (JUNAIDEEN et al., 2004; RAJU, WONG e LOW, 1997). Outros apresentam strain gages instalados nas barras de aço que serão utilizadas como grampos envoltos em calda de cimento (JUNAIDEEN et al., 2004; CHU e YIN, 2005; WONG et al.; 1997; FEIJÓ E EHRLICH, 2005; CHENG, LAWRENCE e HANSEN, 1994).

\subsubsection{Durabilidade dos grampos}

Em obras de médio e longo prazo em solos grampeados, a verificação de sinais de corrosão nos grampos torna-se praticamente obrigatória (FRENCH NATIONAL RESEARCH PROJECT CLOUTERRE, 1991). Este monitoramento é feito através da instalação de grampos que serão extraídos em tempos pré-estabelecidos para se verificar o grau de corrosão que ocorre na obra. Recomenda-se que estes grampos sejam executados da mesma forma que os grampos atuantes, porém mais curtos (1,0 a 1,5 m). No caso do uso de grampos com calda de cimento, os grampos que serão extraídos não devem recebê-la para simular qualquer fissura que permita o contato direto do solo com a barra de aço. As barras extraídas podem 
então ser submetidas à inspeção visual para verificar o grau de corrosão, a uma comparação de pesos depois de ter sido limpa integralmente e a ensaios mecânicos para determinar sua resistência residual à tração.

\subsubsection{Sistema de drenagem e nível piezométrico}

O monitoramento do sistema de drenagem refere-se, basicamente, a inspeções visuais para checar a existência de umedecimento na face e medidas de vazões nos drenos e nos barbacãs, além do nível piezométrico.

\subsection{Considerações de projeto}

Na concepção do projeto de uma estrutura em solo grampeado são levados em consideração diversos parâmetros como o comprimento, o ângulo de instalação, os espaçamentos dos grampos. Feijó e Ehrlich (2005) analisaram a influência da inclinação dos grampos no comportamento global da obra através de ensaios de arrancamento. Os ângulos adotados foram $5^{\circ}, 15^{\circ}$ e $30^{\circ}$. Os grampos inclinados $15^{\circ}$ com a horizontal foram os que suportaram os maiores esforços, o que concorda com o projeto CLOUTERRE (1991), que sugere valores entre $0^{\circ}$ e $20^{\circ}$. Tais parâmetros devem assegurar a estabilidade interna e externa da obra e a sua determinação depende de fatores como a altura e a inclinação da face, a inclinação do talude de montante, o tipo dos grampos além de outras variáveis estabelecidas pelo ambiente.

O dimensionamento de solos grampeados é baseado em métodos de equilíbrio limite em que o solo atrás da face é subdividido em duas regiões, uma ativa e outra passiva, limitadas por uma superfície potencial de ruptura. A inserção dos grampos na zona passiva 
deve garantir um comprimento suficiente para suportar os esforços de arrancamento dos grampos provenientes da zona ativa. As metodologias para o dimensionamento de solos grampeados diferem, basicamente, na forma da superfície de ruptura adotada, no cálculo do equilíbrio das forças atuantes e na natureza destas forças.

Os métodos de equilíbrio limite apresentam-se como uma boa solução quando utilizados com ferramentas computacionais. Este método consiste no cálculo da estabilidade interna e externa da obra. Para a verificação da estabilidade externa, a obra é considerada como um bloco monolítico e se analisa a probabilidade de ocorrência de quatro fenômenos: deslizamento, tombamento, ruptura da fundação e ruptura global (Figura 2.16). Na verificação da estabilidade interna dimensionam-se os grampos para que suportem os esforços, em geral de tração, aos quais serão submetidos e para que não ocorra o arrancamento do reforço de dentro da zona passiva, sempre baseado numa dada distribuição de grampos. É necessário ainda verificar a zona ativa e projetar a face para suportar parte das solicitações nesta região.
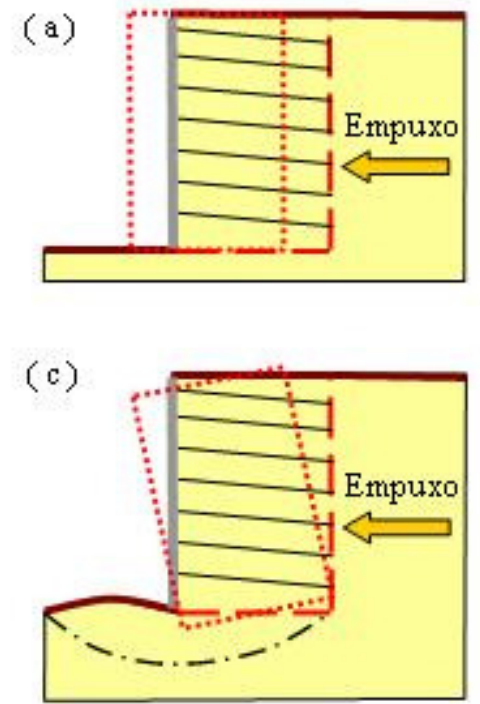

(b)

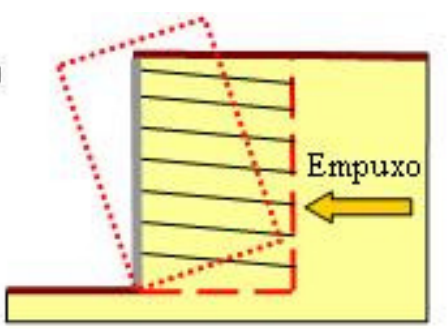

(d)

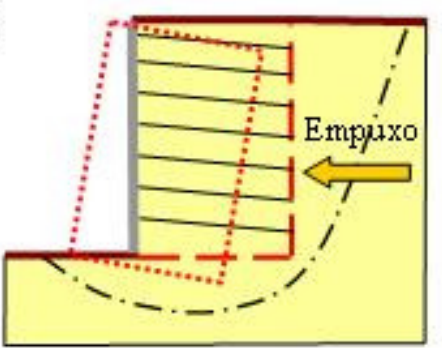

Figura 2.16 - Mecanismos clássicos de instabilização de estruturas de contenção. (a) Deslizamento. (b) Tombamento. (c) Capacidade de carga das fundações. (d) Ruptura global (adaptado de Vertematti et al., 2004). 
Vários autores apresentam a utilização de programas computacionais na concepção de projetos de solo grampeado, na previsão do comportamento da obra ou para a previsão da resistência ao cisalhamento de interface do grampo. Gerscovich, Sieira e Sayão (2005), por exemplo, estudaram a utilização de programas computacionais diferentes, um baseado no método das diferenças finitas $\left(\mathrm{FLAC}^{\circledR}\right)$ e outro no método dos elementos finitos $\left(\right.$ PLAXIS $\left.^{\circledR}\right)$, para o cálculo das deformações da obra durante a escavação. Apesar de terem sido obtidos resultados diferentes, em termos práticos, as diferenças se mostraram desprezíveis.

Oliveira, V., Ferreira e Oliveira, H. (2005) apresentam outro programa computacional $\left(\mathrm{SLIDE}^{\circledR}\right)$ para as análises de estabilidade de taludes em solo grampeado. Eles sugerem a realização da análise da estabilidade em mais de um local do talude e não apenas na seção dita crítica. Sendo assim, a realidade local é mais bem representada e a elaboração do projeto pode ser otimizada. Bridle e Davies (1997), por sua vez, estabeleceram os mecanismos de interação solo-grampo através da observação de experimentos e os incorporaram ao programa computacional CRESOL ${ }^{\circledR}$ para calcular a resistência dos grampos.

Shen et al. (1981) compara os dados obtidos através de instrumentação com aqueles obtidos através de análises pelo método dos elementos finitos. As análises conduziram a valores próximos daqueles obtidos pela instrumentação, exceto para escavações em maiores profundidades. Os autores citam que isso, possivelmente, se deve a maior rigidez do solo com a profundidade do que a adotada na modelagem numérica.

Alguns autores propõem formas de abordagem diferentes para os projetos de solos grampeados. Gässler e Gudehus (1983), por exemplo, propõem uma análise dos solos grampeados através de estudos estatísticos e da Teoria da Probabilidade. Eles citam que adotar um valor mínimo de fator de segurança é subjetivo e pode gerar uma informação 
apenas aproximada do risco de ruptura. Apresentam ainda que fatores de segurança parciais de 1,1 para o atrito de interface e para a sobrecarga e 1,3 para as forças no grampo resultaram numa probabilidade de ruína de $10^{-6}$ para a obra estudada.

\subsection{Obtenção dos parâmetros de projeto}

Os parâmetros necessários ao projeto em solo grampeado são obtidos por investigações geotécnicas (parâmetros de solo) e por ensaios nos grampos.

\subsubsection{Investigações Geotécnicas}

O objetivo das investigações geotécnicas é fornecer dados relativos ao comportamento dos solos. Eles serão utilizados no projeto e na execução dos solos grampeados e também no monitoramento da interação entre a obra e estruturas vizinhas.

As investigações geotécnicas definem um programa de investigação que prevê uma região para verificação das características do subsolo. O projeto CLOUTERRE (1991) recomenda que as investigações geotécnicas sejam executadas até uma distância mínima de uma vez e meia a altura do muro, quando o terreno de montante for horizontal, e três vezes quando o terreno de montante for inclinado (Figura 2.17).

Sugere-se que ensaios in situ e de laboratório sejam executados para identificar o solo, determinar seus parâmetros de resistência e medir a resistência ao cisalhamento de interface, a partir de ensaios pressiométricos, por exemplo. A identificação de solos não coesivos se resume à análise granulométrica e a determinação do teor de umidade natural. Em solos coesivos devem ainda ser determinados os limites de Atterberg, massa específica total e massa específica seca. 


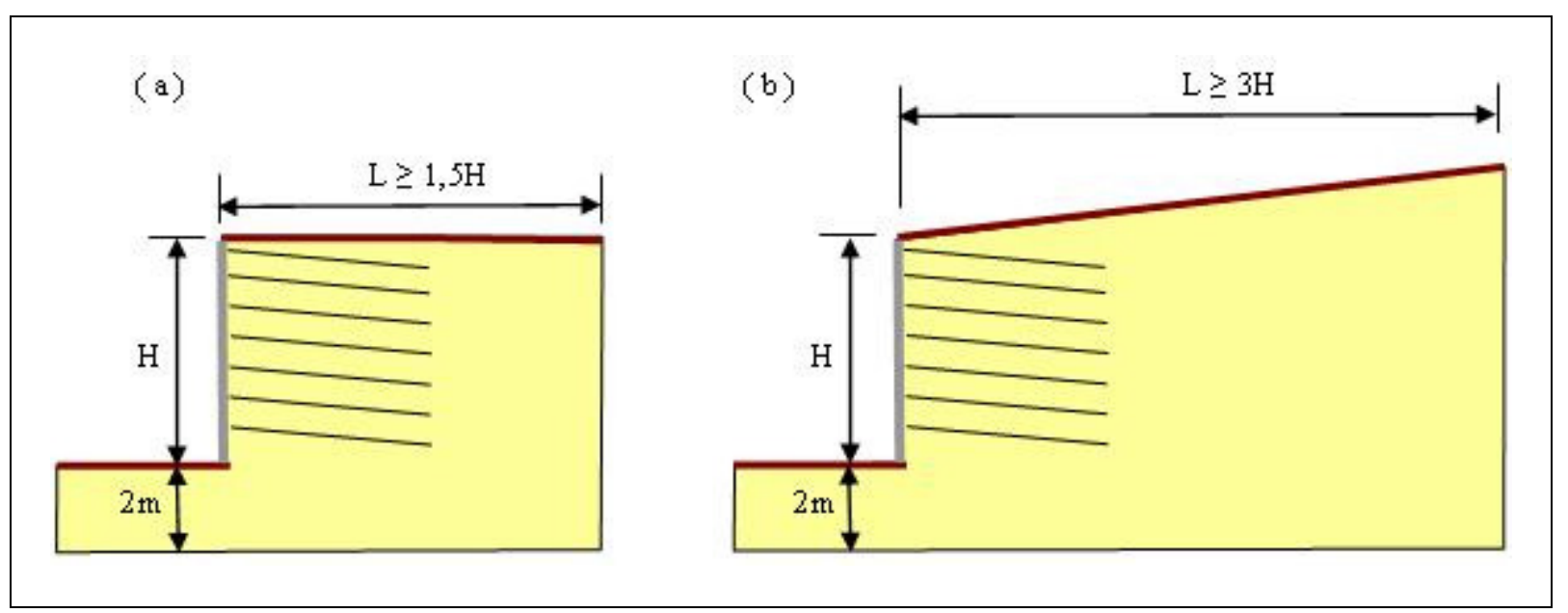

Figura 2.17 - Limites da área onde devem ser executadas as investigações geotécnicas. (a)

Taludes sem inclinação à montante. (b) Talude com inclinação à montante (FRENCH NATIONAL RESEARCH PROJECT CLOUTERRE, 1991).

Os parâmetros de resistência devem ser determinados por ensaios triaxiais, de cisalhamento direto ou de arrancamento. Nos materiais não coesivos, as correlações entre o ângulo de atrito interno e os ensaios de SPT (Standard Penetration Test) e CPT (Cone Penetration Test) podem ser utilizadas. Para solos coesivos recomenda-se a determinação dos parâmetros de resistência nas situações de curto e longo prazo, através de ensaios triaxiais não drenados e drenados, respectivamente.

É importante determinar o potencial corrosivo dos solos devido a seu contato direto com os grampos. O projeto CLOUTERRE (1991) sugere um índice de potencial corrosivo baseado no tipo, resistividade, teor de umidade e $\mathrm{pH}$ do solo. Estudos hidrogeológicos devem ser executados para determinar o nível d'água e suas variações bem como o regime de fluxo que ocorre no solo.

Smith (1992) estudou a influência da geologia local em ensaios de arrancamento em Hong Kong, China. Dentre as suas conclusões, pode-se destacar que as deformações dos grampos em rochas muito fraturadas possuem a mesma ordem de grandeza daquelas em saprolito, dependem significativamente das condições, natureza e origem do transporte, nos 
solos transportados, e apresentam-se com a mesma ordem de grandeza em diferentes tipos de rochas.

\subsubsection{Ensaios nos grampos}

Os ensaios nos grampos consistem basicamente em ensaios de arrancamento, cujo objetivo é determinar a resistência ao cisalhamento de interface, parâmetro fundamental para o projeto de solos grampeados. É interessante também verificar o comportamento das curvas de atrito de interface em relação ao deslocamento relativo entre o solo e o grampo. A resistência ao cisalhamento de interface é definida por:

$$
\mathrm{q}_{\mathrm{s}}=\frac{\mathrm{F}_{\text {srr }}}{\pi \mathrm{DL}}
$$

Onde: $\mathrm{q}_{\mathrm{s}}$ é a resistência ao cisalhamento de interface, $\mathrm{F}_{\text {arr }}$ é a força de arrancamento, D é o diâmetro do grampo e L é o comprimento do grampo em contato com o solo.

Os projetos de solo grampeado consideram o estado limite último da estrutura. Portanto, é preciso que o atrito de interface seja estimado inicialmente. A experiência local deve ser levada em consideração nesta estimativa. Os ensaios devem ser executados, portanto, na fase de projeto, para estabelecer tais parâmetros, durante a execução, a título de comprovação, e após a conclusão da obra, para o monitoramento.

A resistência ao cisalhamento de interface pode ser afetada, principalmente, pelo tipo e condições do solo, rugosidade e diâmetro do furo onde os grampos serão instalados, pela técnica de escavação e preenchimento do furo utilizadas e do tempo que este permanece aberto antes de ser preenchido (FHWA, 1998).

O projeto CLOUTERRE (1991) apresenta uma sugestão do número mínimo de 
grampos a serem ensaiados segundo a área de solo grampeado a ser executada (Tabela 5.1). Esta recomendação é feita segundo a área de cada tipo de solo que o perfil a ser escavado apresente. Os grampos são instalados no terreno na camada de solo a ser ensaiada (Figura 2.18).

Tabela 5.1 - Número de ensaios de arrancamento que devem ser executados segundo a área total de solo grampeado (FRENCH NATIONAL RESEARCH PROJECT CLOUTERRE, 1991).

\begin{tabular}{cc}
\hline Área da face $\left(\mathrm{m}^{2}\right)$ & $\begin{array}{c}\text { Número de } \\
\text { ensaios }\end{array}$ \\
\hline Até 800 & 6 \\
De 800 a 2000 & 9 \\
De 2000 a 4000 & 12 \\
De 4000 a 8000 & 15 \\
De 8000 a 16000 & 18 \\
De 16000 a 40000 & 25 \\
\hline
\end{tabular}

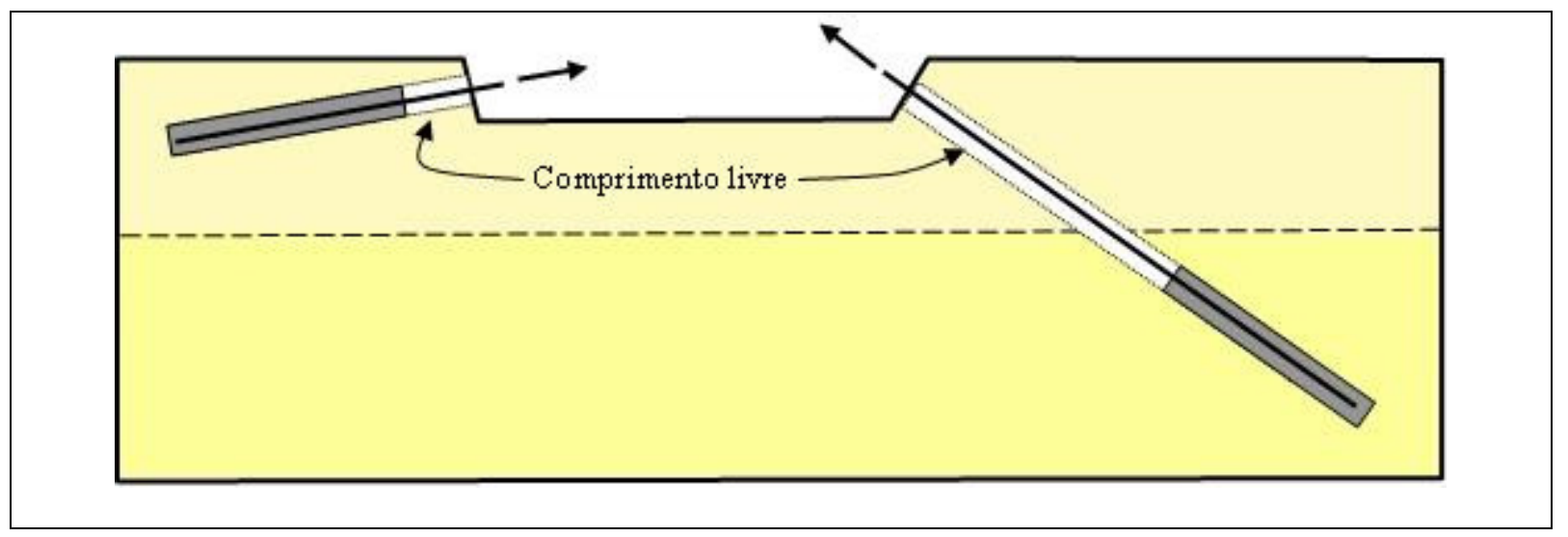

Figura 2.18 - Esquema para ensaios de arrancamento em diferentes camadas de solo (FRENCH NATIONAL RESEARCH PROJECT CLOUTERRE, 1991).

Na etapa construtiva, os ensaios de arrancamento possuem caráter obrigatório, devendo ser executados em mesmo número do que aqueles para a verificação das suposições 
quanto à resistência ao cisalhamento de interface. É importante distribuir os ensaios por toda a estrutura.

Os grampos a serem ensaiados durante a construção devem ser previamente preparados para tal e instalados entre os grampos de serviço. Estes grampos são mais curtos, possibilitando levá-los até a ruptura. Estas verificações possuem caráter obrigatório e devem ser executados pelo menos cinco ensaios para até $1.000 \mathrm{~m}^{2}$ de face, com um mínimo de um ensaio para cada nível de escavação. Acima deste valor, deve ser acrescentado um ensaio para cada $200 \mathrm{~m}^{2}$ de face. O número total deve ser distribuído igualmente por toda a obra. Falconi e Alonso (1997) alegam que a execução de um ensaio de arrancamento a cada dez grampos executados pode ser representativa da obra.

Os ensaios de arrancamento devem obedecer a algumas considerações. O comprimento livre deve ser protegido por um tubo para evitar qualquer contato da barra com o solo. A instalação dos equipamentos para o arrancamento deve ser feita de tal modo a não impor nenhuma flexão ao grampo.

Os ensaios de arrancamento podem ser executados de duas formas: com deslocamento constante e em estágios de carregamento. Ambos os procedimentos requerem basicamente os mesmos equipamentos (Figura 2.19). Os ensaios com velocidade constante permitem determinar a força de arrancamento máxima, a força residual e a inclinação inicial da curva força-deslocamento. A partir desta curva podem ser determinadas as resistências ao cisalhamento de interface máxima e a residual, além da inclinação inicial da curva de mobilização do atrito de interface. Os ensaios em estágios de carregamento resultam na tração de fluência crítica e, eventualmente, na força de tração limite do grampo. 


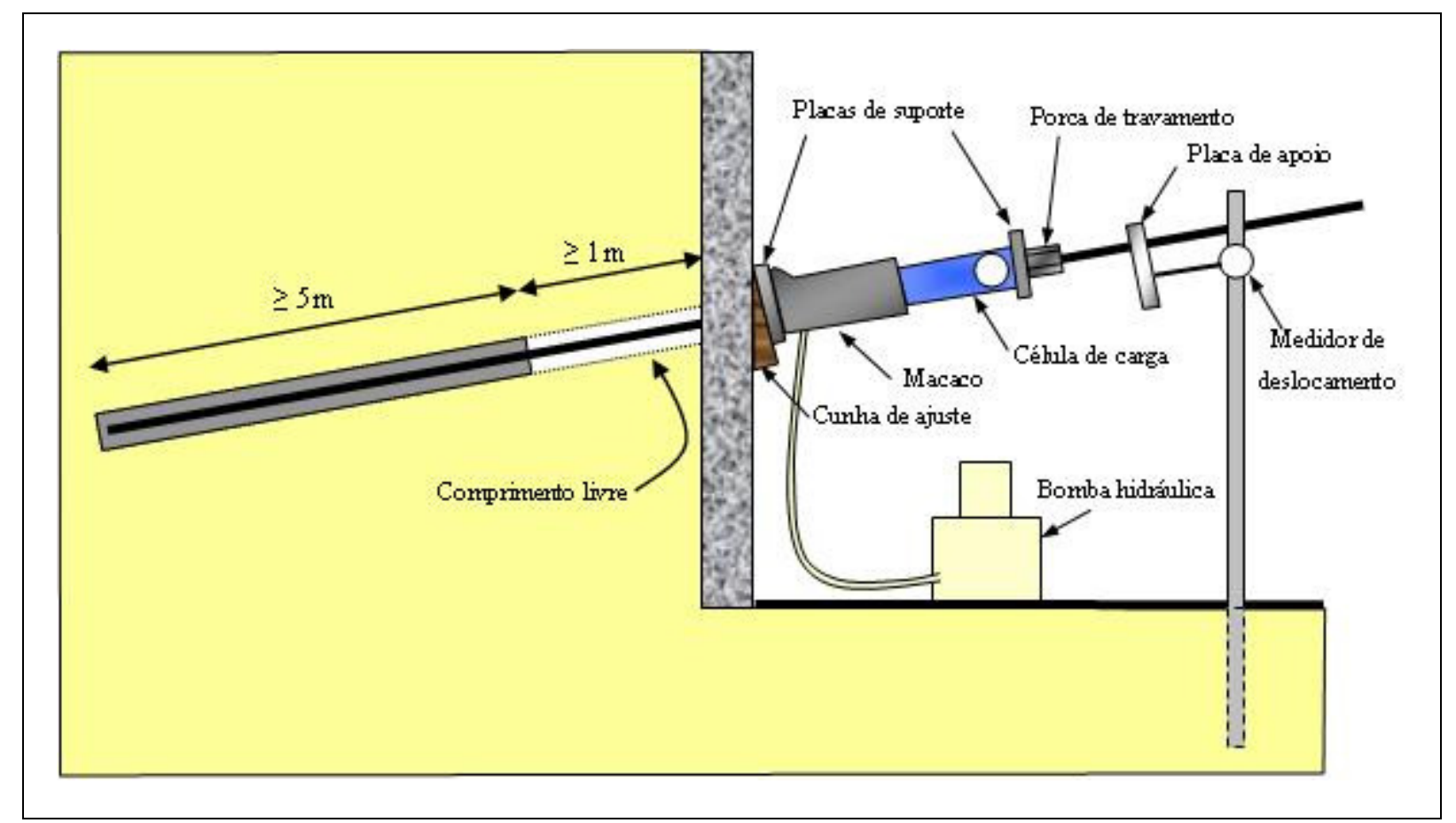

Figura 2.19 - Esquema para ensaios de arrancamento in situ em solos grampeado (FRENCH NATIONAL RESEARCH PROJECT CLOUTERRE, 1991).

Nos ensaios de arrancamento com velocidade constante, os grampos são carregados a um deslocamento constante da ordem de $1 \mathrm{~mm} / \mathrm{min}$. Sugere-se que as leituras sejam realizadas a cada $0,1 \mathrm{~mm}$ até $5 \mathrm{~mm}$ de deslocamento e a partir deste valor, a cada 0,5 $\mathrm{mm}$, até atingir a carga residual. As curvas força de arrancamento $\mathrm{x}$ deslocamento apresentam-se basicamente de três formas (Figura 2.20). Para o caso da terceira curva apresentada (Figura 20c), que não possui uma carga de ruptura definida, sugere-se que o ensaio deve prosseguir até que a força no grampo varie menos de $1 \%$ para $1 \mathrm{~mm}$ de deslocamento (FRENCH NATIONAL RESEARCH PROJECT CLOUTERRE, 1991). Durante o descarregamento, as leituras devem ser realizadas a cada décimo da força máxima aplicada.

O primeiro passo para a execução dos ensaios de arrancamento em estágios de carregamento é a realização de ensaios de arrancamento com deslocamento constante para 
determinar a força máxima de arrancamento. O grampo é então gradualmente sujeito a forças de arrancamento, que são aumentadas em estágios, mas que devem permanecem abaixo do limite elástico do reforço para limitar a fluência do aço. Cada estágio é mantido por um tempo pré-determinado, semelhante a ensaios de prova de carga estática em estacas. Os deslocamentos são medidos em tempo pré-estabelecidos durante cada estágio. Devem ser tomadas medidas de temperatura durante todo o ensaio.
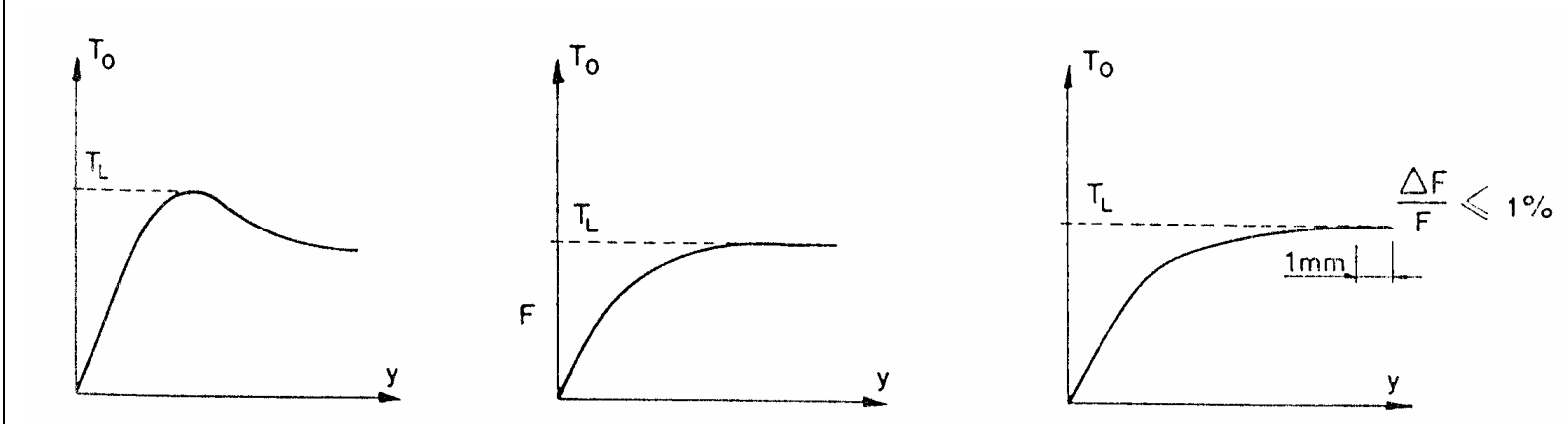

Figura 2.20 - Critérios de ruptura utilizados nos ensaios de arrancamento (FRENCH NATIONAL RESEARCH PROJECT CLOUTERRE, 1991).

Para cada estágio de carregamento, a curva de fluência é caracterizada por um aumento na inclinação da tangente a esta curva. A partir destes dados pode-se plotar estas inclinações em função do nível de carregamento e determinar a tensão de escoamento crítica.

O tipo de grampo nos ensaios deve ser exatamente igual àquele definido em projeto, com todos os parâmetros iguais (inclinação, método de perfuração ou cravação e calda de cimento, se for o caso). Contudo, a barra pode ter resistência maior para assegurar a ruptura por falta de aderência entre o solo e o grampo. A parte do grampo que resistirá aos esforços (cravada ou com material de preenchimento) deve ter o comprimento real dos grampos ou um mínimo de $5 \mathrm{~m}$. Para evitar influências da face sobre o comportamento do grampo, deve-se estabelecer um comprimento livre mínimo de $1 \mathrm{~m}$ a partir da face. Porém, o comprimento livre pode ser muito maior em casos de ensaios em materiais mais profundos 
(Figura 2.18).

A estimativa de um valor de resistência ao arrancamento do grampo pode ser uma tarefa árdua devido aos vários fatores envolvidos. Por este motivo, recomenda-se a comprovação destes valores através de ensaios em campo. Contudo, tais ensaios podem se tornar inconvenientes em relação a custos e dificuldades de acesso à obra, bem como a algumas incertezas (tensão normal, superfície interna do furo onde será instalado o grampo, tempo de cura da calda de cimento etc.). Adiciona-se ainda que, em geral, os ensaios de arrancamento in situ não são realizados nos solos em sua pior condição (saturados), pois são normalmente executados fora do período de chuvas.

Jewell (1983) relata ainda que existe uma grande diferença entre as deformações e os acréscimos de tensão no solo devido à presença dos reforços e o solo em repouso com os reforços sofrendo deslocamento e processos de arrancamento. Apesar disso, os ensaios de arrancamento são usados por construtores e pesquisadores por ser a forma mais fácil e barata de determinar a resistência ao cisalhamento de interface.

Assim, alguns estudos divulgaram equipamentos utilizados em ensaios de arrancamento de pequeno porte, executados em laboratório. Tais ensaios visam aumentar a precisão da estimativa de resistência ao arrancamento dos grampos bem como possibilitar uma análise paramétrica sobre os fatores que influem nesse parâmetro (grau de compactação e teor de umidade do solo, tipo de grampo etc.).

Chu e Yin (2005) construíram um equipamento de laboratório para a execução de ensaios de arrancamento em pequena escala. Eles estudaram a influência da tensão normal, do grau de saturação do solo e da rugosidade da superfície interna do grampo. Tensões normais maiores resultaram em maiores resistências ao arrancamento. A resistência ao arrancamento se mostrou significativamente dependente do grau de saturação do solo, com valores maiores 
para menores graus de saturação. Em relação à rugosidade da superfície interna do furo, os autores encontraram valores maiores de ângulo de atrito de interface e menores de adesão para os grampos executados em furos mais rugosos.

Junideen et al. relatam a construção de um equipamento para ensaio de arrancamento em grande escala, em laboratório, que permitiu a execução de uma linha completa de grampos. Este estudo verifica a influência do tipo de barra de aço utilizada como grampo bem como o comportamento da resistência ao arrancamento dos grampos frente à variação de tensão normal. Dentre as principais conclusões pode-se destacar que as barras com nervuras tem uma influência significativa na resistência ao arrancamento, contudo, grampos executados com essas barras de aço apresentaram uma variação pouco significativa de resistência ao cisalhamento de interface para tensões normais diferentes.

Os ensaios de arrancamento executados em laboratório em geral, não permitem a verificação do comportamento do solo grampeado por se tratarem da execução de um grampo, ou uma linha destes. Alguns autores estudam o comportamento de modelos de solo grampeado ensaiados em centrífuga para suprir a necessidade de entender o seu comportamento. Contudo, tais estudos não permitem a execução de ensaios de arrancamento (TEI; TAYLOR; MILLIGAN, 1998; ZHANG et al., 2001).

Raju, Wong e Low (1997) divulgaram um estudo sobre o comportamento de um modelo de solo grampeado em grande escala. O modelo foi construído de forma a representar um muro em solo grampeado. Apesar de apresentarem resultados sobre o comportamento do modelo, ensaios de arrancamento não foram executados. 


\section{Capítulo 3 - Materiais e Métodos}

Esta pesquisa avaliou o comportamento de um protótipo de uma estrutura de solo grampeado construída em laboratório. A análise baseou-se em dados provenientes de ensaios de arrancamento dos grampos, medições dos deslocamentos do maciço reforçado durante e após a construção e na determinação das forças nos grampos através de strain gages instalados nas barras de aço. Este capítulo descreve as características dos equipamentos e materiais utilizados para a construção do protótipo de solo grampeado em laboratório. São descritos também os procedimentos adotados nesta pesquisa.

\subsection{Caixa de ensaio}

O protótipo de solo grampeado foi construído em uma caixa metálica desenvolvida por Viana (2003). A caixa de ensaio é composta por peças metálicas (pilares, paredes e tampa) rígidas que garantem um estado plano de deformações (Figura 3.1a). Adaptou-se a face frontal da caixa de ensaio de forma a simular as sucessivas etapas de escavação inerentes à técnica de solo grampeado. A face frontal adaptada é composta por seis 
segmentos retangulares de madeira com $50 \mathrm{~mm}$ de espessura e $250 \mathrm{~mm}$ de altura, exceto pelo segmento inferior, que possui $425 \mathrm{~mm}$ de altura (Figura 3.1b). Cada segmento simulou uma fase de escavação que precede a instalação de uma linha de grampos. A caixa de ensaio adaptada apresenta área plana de 1,80 x 1,55 m (B x L) e altura de 1,80 m (Figura 3.1a). As paredes laterais da caixa de ensaio foram forradas com uma montagem de geomembranas de PVC com graxa entre elas (Figura 3.1a). Esta medida visou reduzir o atrito entre as paredes laterais da caixa de ensaio e o solo. A seção vertical central foi tomada como representativa do comportamento da estrutura em solo grampeado.
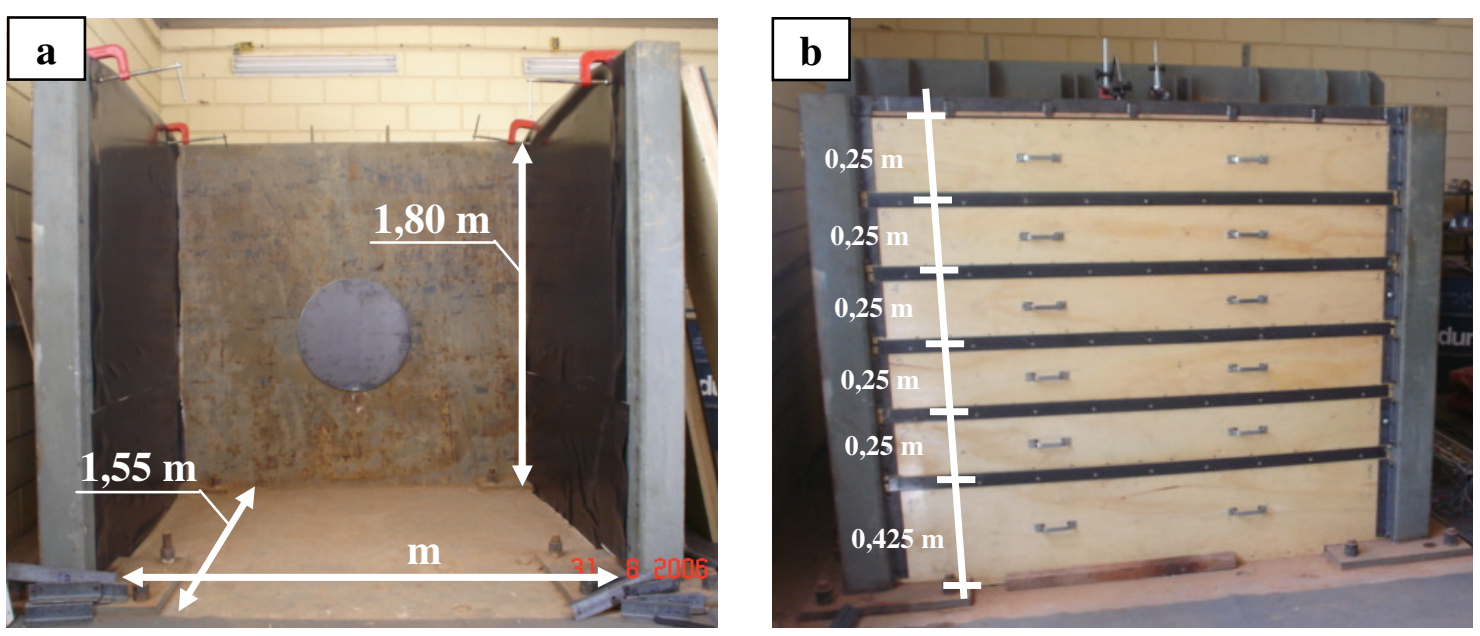

Figura 3.1 - Dimensões internas da caixa de ensaio metálica utilizada nesta pesquisa (a) e face frontal adaptada para a construção do protótipo de solo grampeado (b).

O planejamento da construção do solo grampeado previu um protótipo com 1,70 $\mathrm{m}$ de altura e espaçamentos vertical e horizontal entre grampos iguais a $250 \mathrm{~mm}$. Optouse pela execução de grampos envolvidos por calda de cimento, por serem o tipo mais comumente executado no Brasil.

Os grampos foram dimensionados com $1,30 \mathrm{~m}$ de comprimento e $27 \mathrm{~mm}$ de diâmetro, utilizando barras de aço CA-50 com $8 \mathrm{~mm}$ de diâmetro nominal. O comprimento dos grampos foi escolhido com base nas recomendações de projeto de Bruce e Jewell (1987) e 
do French National Research Project Clouterre (1991), que sugerem uma relação entre o comprimento dos grampos e a altura da contenção $(\mathrm{L} / \mathrm{H})$ entre 0,5 e 1,2. Os diâmetros dos grampos e das barras de aço apresentam-se menores que aqueles encontrados comumente na prática atual dos solos grampeados (20 a $32 \mathrm{~mm}$ ) e nas recomendações de projeto de Bruce e Jewell (1987) e do French National Research Project Clouterre (1991), que citam valores entre 50 e $600 \mathrm{~mm}$ para os grampos e 16 a 57,2 $\mathrm{mm}$ para as barras de aço. Os grampos foram assim dimensionados para permitir uma maior densidade de grampos na caixa de ensaio.

A inclinação dos grampos foi definida na etapa de planejamento e considerada igual a $10^{\circ}$. Este valor encontra-se dentro dos limites propostos por Bruce e Jewell (1987), de $10^{\circ}$ a $15^{\circ}$, e do French National Research Project Clouterre (1991), de $5^{\circ}$ a $20^{\circ}$.

O projeto do protótipo de solo grampeado previu a construção de uma estrutura pertencente à Categoria II proposta por James (1971). A referida categoria trata de modelos que são projetados como pequenos protótipos e verifica seu comportamento em relação àquele previsto por alguns métodos de análise. Os requisitos básicos para a construção de modelos da Categoria II são: o solo deve possuir um estado uniforme e a influência das paredes e demais limites da caixa de ensaio deve ser ignorada. Estes requisitos foram propositalmente previstos na etapa de projeto do protótipo de solo grampeado e atendidos durante a construção.

\subsection{Solo}

O solo utilizado nesta pesquisa foi coletado no município de São Carlos (SP), caracterizado através dos ensaios de análise granulométrica, limites de Atterberg, massa específica dos sólidos e compactação (Energia Normal). Kakuda (2005) realizou também 
ensaios de cisalhamento direto no solo utilizado nesta pesquisa, compactado com um grau de compactação igual a 96\%. Os resultados dos referidos ensaios são apresentados na Tabela 3.1. A Figura 3.2 apresenta a curva granulométrica e a curva de compactação (teor de umidade ótimo igual a $16,0 \%$ e peso específico seco máximo igual a $17,85 \mathrm{kN} / \mathrm{m} 3$ ). Trata-se de uma areia argilosa de média plasticidade ou SC, segundo o Sistema Unificado de Classificação dos Solos.

Tabela 3.1 - Resumo da caracterização geotécnica do solo utilizado nesta pesquisa.

\begin{tabular}{cc}
\hline Propriedade & Valor \\
\hline Peso específico dos sólidos & $26,42 \mathrm{kN} / \mathrm{m}^{3}$ \\
Limite de liquidez & $39 \%$ \\
Limite de plasticidade & $21 \%$ \\
Índice de plasticidade & $18 \%$ \\
Peso específico seco máximo (Energia Normal) & $17,85 \mathrm{kN} / \mathrm{m}^{3}$ \\
Teor de umidade ótimo (Energia Normal) & $16 \%$ \\
Teor de areia & $62 \%$ \\
Teor de silte & $4 \%$ \\
Teor de argila & $34 \%$ \\
Classificação SUCS & $\mathrm{SC}$ \\
Coesão (GC $=96 \%)$ & $34,6 \mathrm{kPa}$ \\
Ângulo de atrito interno $(\mathrm{GC}=96 \%)$ & $30,0 \mathrm{kPa}$ \\
\hline
\end{tabular}

\subsection{Reforços (grampos)}

Os reforços do protótipo de solo grampeado consistiram de barras de aço (CA-50) inseridas em furos executados no maciço de solo, preenchidos, em seguida, com calda de cimento. O espaçamento (vertical e horizontal) entre os grampos foi mantido constante e igual a $250 \mathrm{~mm}$. A perfuração foi realizada com trado manual $(25,4 \mathrm{~mm}$ de diâmetro) numa inclinação de $10^{\circ}$ com a horizontal, resultando em furos com $27 \mathrm{~mm}$ de diâmetro e 1,32 $\mathrm{m}$ de 
comprimento. Garantiu-se a inclinação dos grampos com a utilização de dois suportes metálicos (Figura 3.3). As barras de aço possuem 1,8 $\mathrm{m}$ de comprimento e $8 \mathrm{~mm}$ de diâmetro nominal. O comprimento excedente da barra de aço em relação ao furo foi utilizado para a execução dos ensaios de arrancamento.

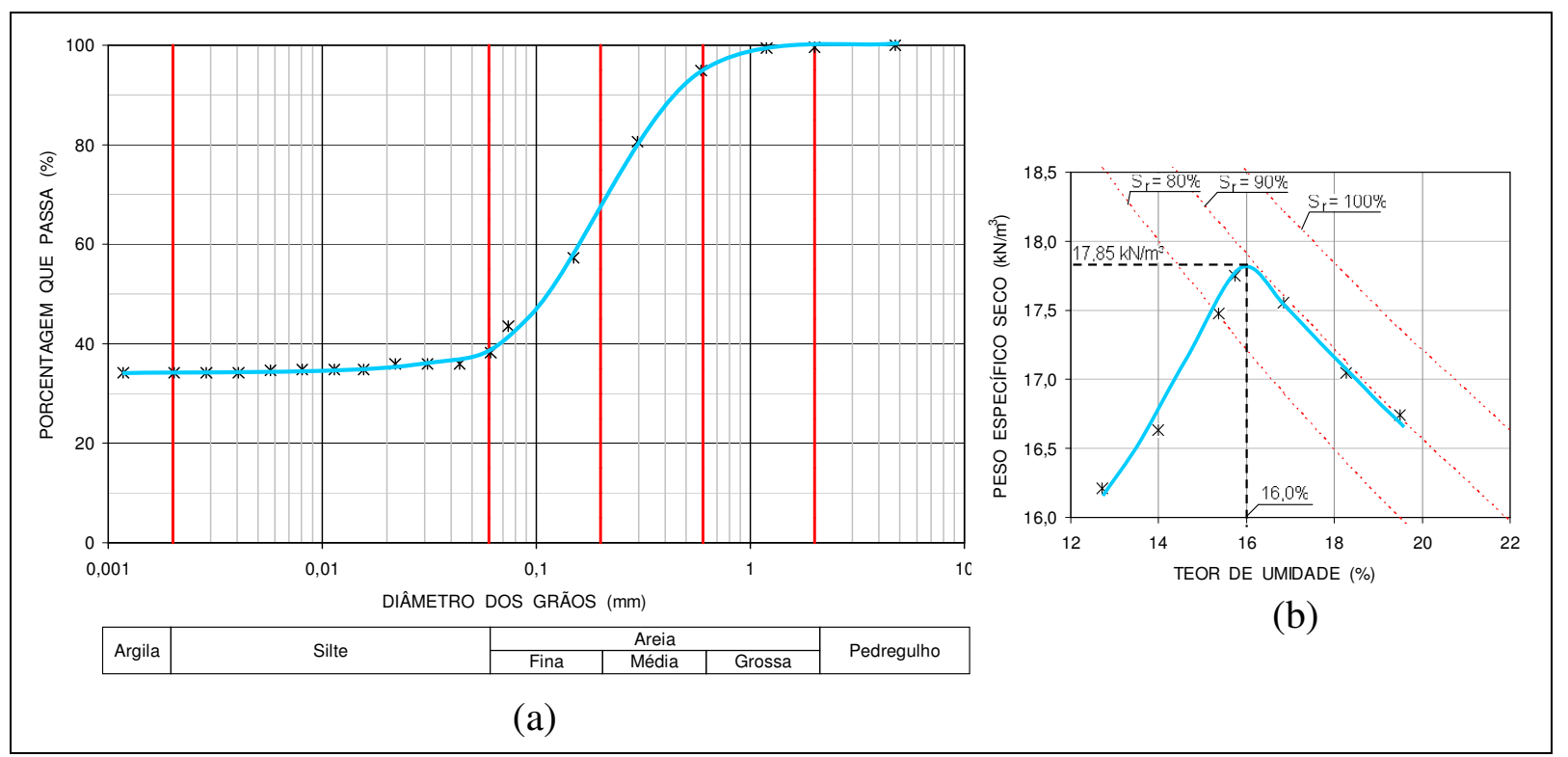

Figura 3.2 - (a) Curva granulométrica e (b) curva de compactação com energia normal obtidas para o solo utilizado nesta pesquisa.

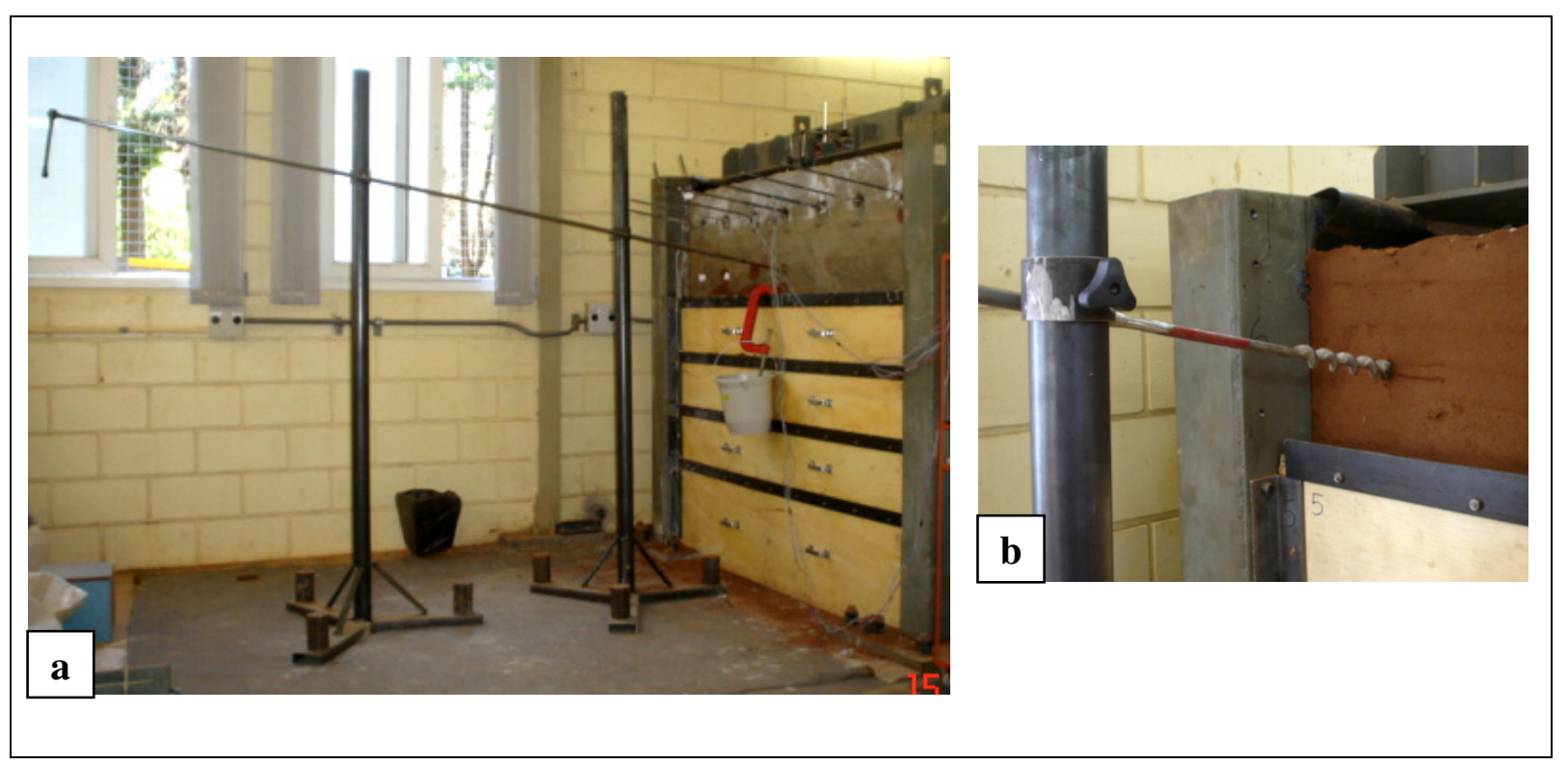

Figura 3.3 - Suportes utilizados para a perfuração com inclinação de $10^{\circ}$ com a horizontal (a) e detalhe do trado utilizado nesta operação (b). 
Utilizou-se cimento de alta resistência inicial para a produção da calda de cimento, com fator água-cimento igual a 0,5 em peso. A calda de cimento foi preparada em quantidade suficiente para o preenchimento dos furos e moldagem de nove corpos de prova para cada linha de grampos. Os corpos de prova foram moldados ao longo da execução dos grampos de uma mesma linha e levados ao processo de cura submersa após o tempo de pega (Figura 3.4).
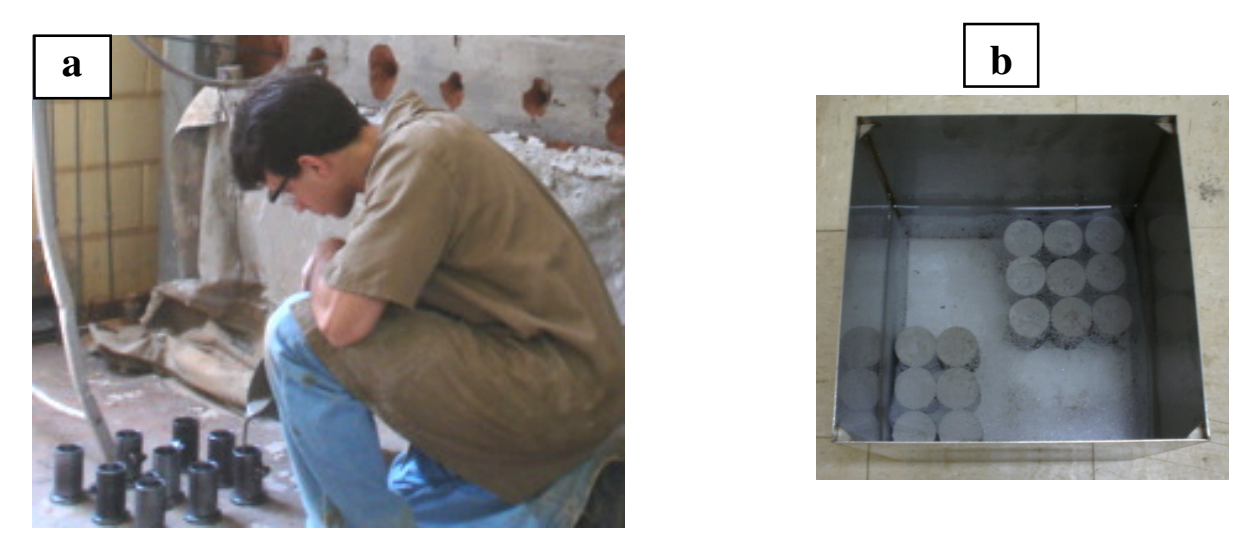

Figura 3.4 - Moldagem de corpos de prova da calda de cimento durante a execução de uma linha de grampos (a) e exemplo dos mesmos em cura submersa (b).

A resistência à compressão uniaxial da calda de cimento foi determinada através de ensaios em laboratório para três tempos de cura diferentes: um, três e sete dias. Cada determinação consistiu da ruptura de três corpos de prova de cada linha de grampos. Moldaram-se ainda corpos de prova adicionais para as linhas $\mathrm{L}_{5}$ e $\mathrm{L}_{6}$, com o objetivo de obter um valor de resistência à compressão uniaxial para 14 dias de cura submersa. A resistência à compressão uniaxial apresentou-se igual a cerca de $45 \mathrm{MPa}$, com sete dias de cura submersa (Figura 3.5).

Foram executados 42 grampos, numa malha $6 \times 7$ (linhas x colunas), numerados segundo a sua localização na caixa de ensaio (Figura 3.6). Doze grampos foram instrumentados com extensômetros elétricos (strain gages), indicados na Figura 3.6. O item 
3.4 apresenta maiores detalhes sobre a instrumentação com strain gages e com relógios comparadores.

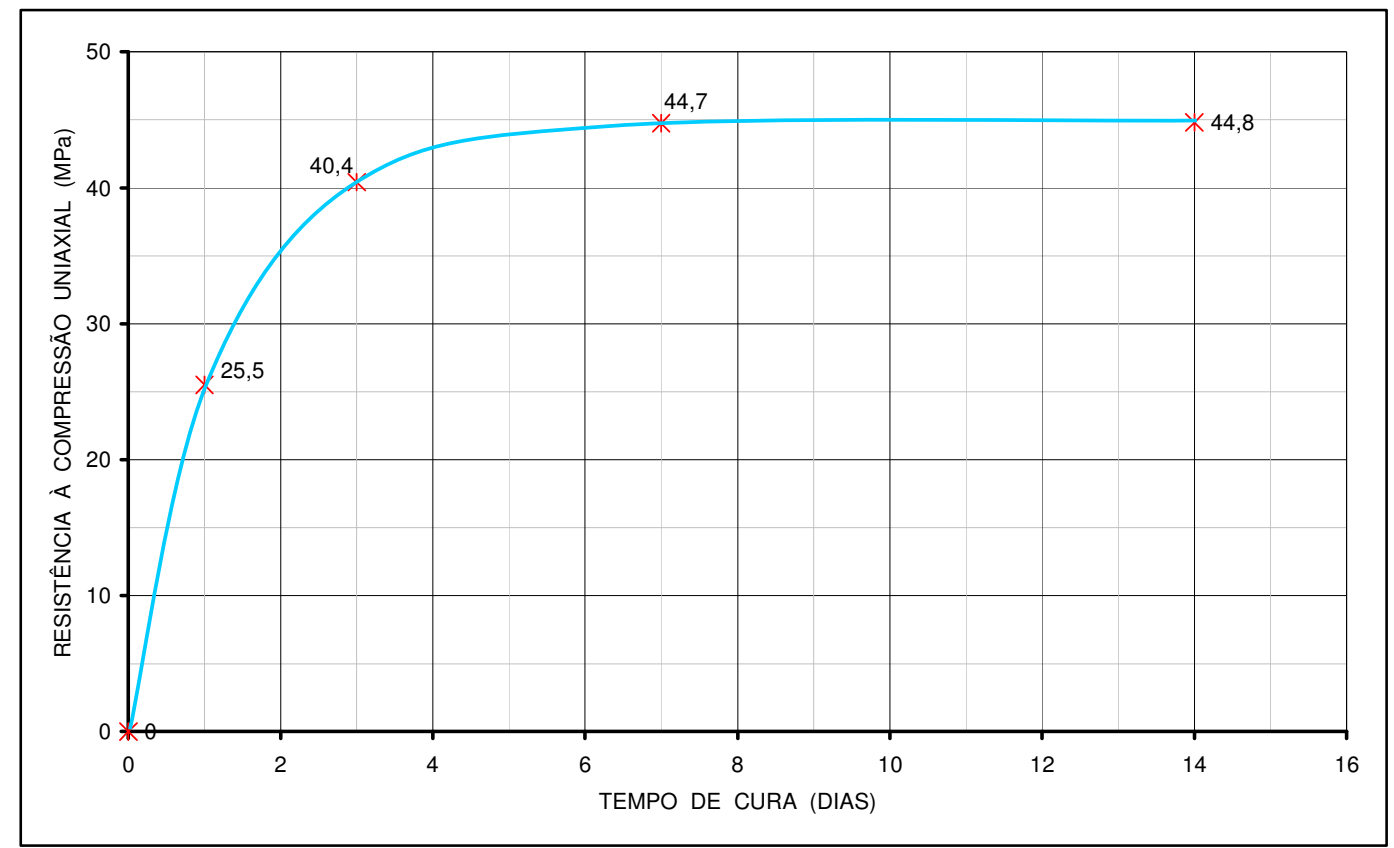

Figura 3.5 - Evolução da resistência à compressão uniaxial da calda de cimento segundo o tempo de cura submersa.

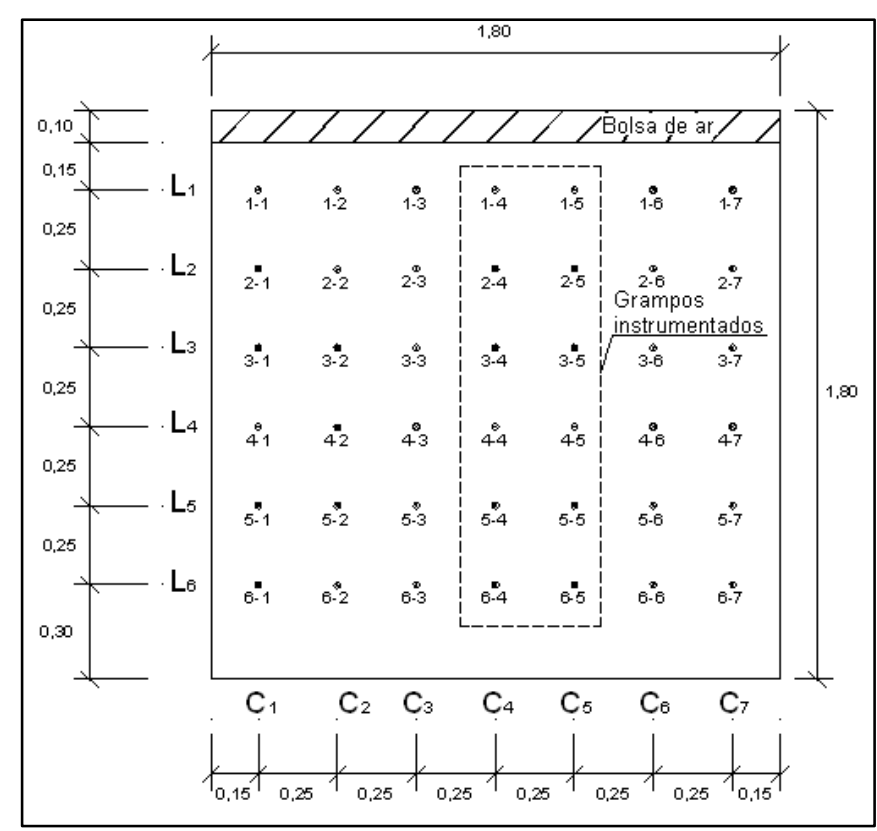

Figura 3.6 - Localização dos grampos no protótipo de solo grampeado com destaque para as seções verticais centrais, instrumentadas com strain gages. 


\subsection{Instrumentação}

A instrumentação consistiu na instalação de strain gages ao longo dos grampos e em medidas de deslocamento da face, durante e após a construção, além de equipamentos dos dados coletados ao longo dos ensaios de arrancamento.

Os strain gages foram instalados em quatro pontos diferentes de cada grampo, alinhados na lateral das barras de aço para reduzir a influência de possíveis momentos fletores. A Figura 3.7 apresenta a seção vertical central do protótipo de solo grampeado, considerada como representativa de comportamento do mesmo. Nela é apresentada a localização dos extensômetros elétricos em cada barra de aço.

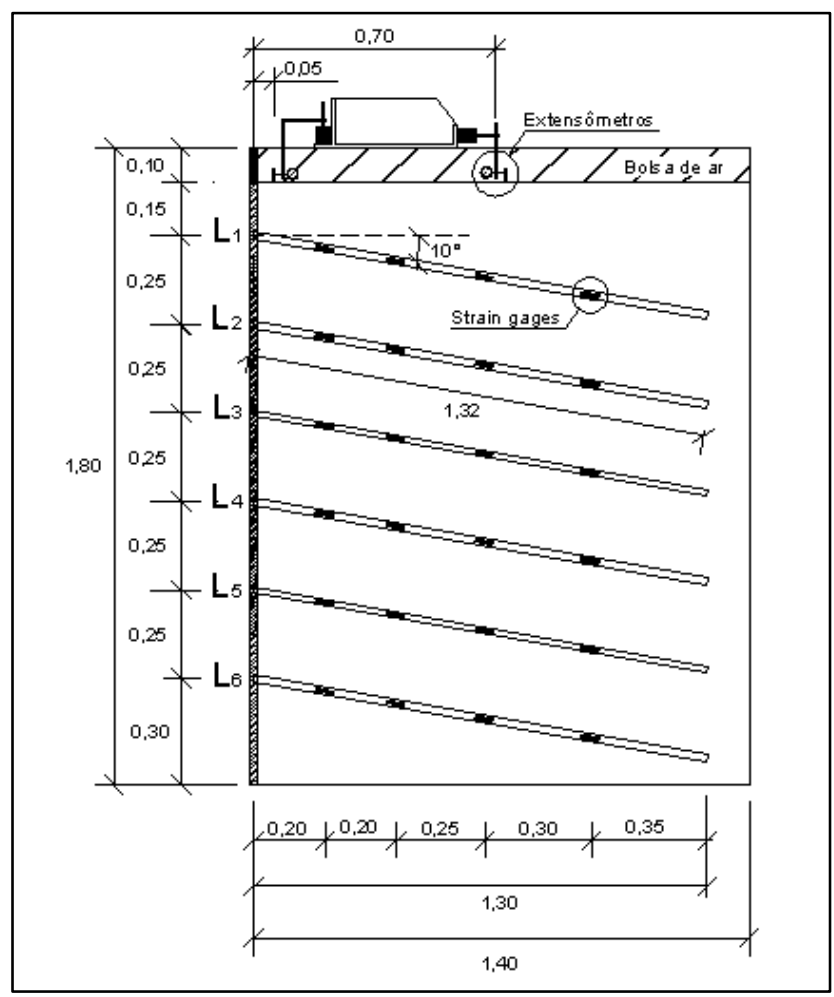

Figura 3.7 - Seção vertical central do protótipo de solo grampeado, tomada como representativa do comportamento do mesmo. 
A correta interpretação das leituras dos strain gages exige uma calibração apropriada dos mesmos. Para tanto, as barras de aço instrumentadas foram carregadas sob tração (Figura 3.8a) em estágios, crescentes e decrescentes, para verificar as leituras de cada strain gage em cada nível de carregamento. Em seguida, cada estágio foi relacionado a uma leitura do strain gage, resultando nas curvas de calibração (Figura 3.8b). Foram utilizados nove estágios de carregamento com variação de $0,54 \mathrm{kN}$. Cada estágio, portanto, corresponde a uma variação de tensão de tração de aproximadamente 10,7 MPa para as barras de aço com $8 \mathrm{~mm}$ de diâmetro nominal. A Figura $3.8 \mathrm{~b}$ apresenta o comportamento típico encontrado no processo de calibração das barras de aço instrumentadas e a curva de calibração típica dos strain gage.
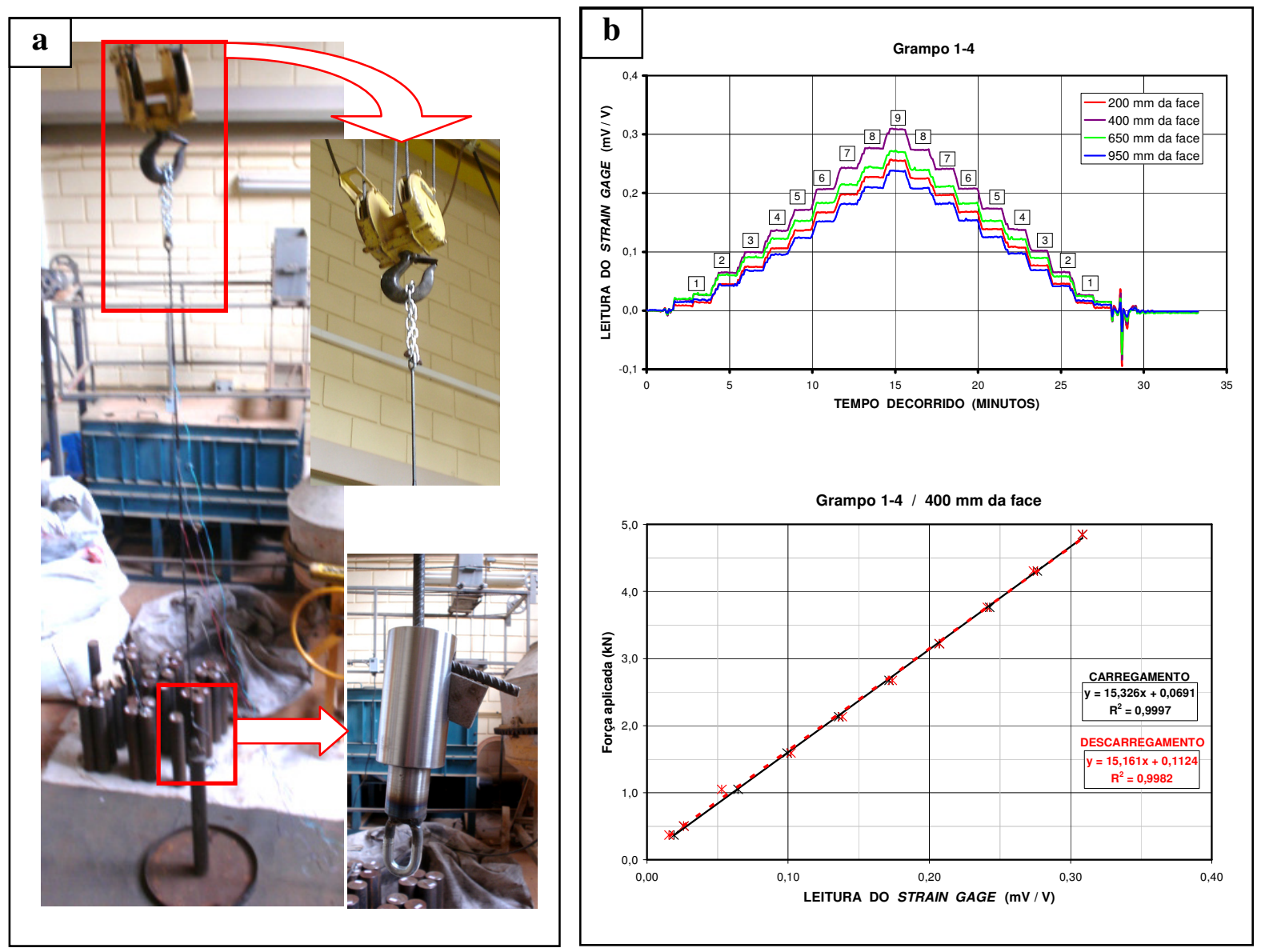

Figura 3.8 - Calibração dos strain gages: a) Equipamentos utilizados no procedimento; b) Gráficos típicos produzidos no processo de calibração dos strain gages. 
Os deslocamentos da face foram medidos durante e após a construção do protótipo. Utilizaram-se relógios comparadores instalados na superfície do protótipo durante a construção (Figura 3.9). A $50 \mathrm{~mm}$ da face foram dispostos dois relógios comparadores para medidas de deslocamento horizontal e vertical da face. Um terceiro relógio comparador foi posicionado a $750 \mathrm{~mm}$ da face para medida dos deslocamentos horizontais. Optou-se pela instalação dos relógios comparadores na superfície do protótipo, pois é o local onde ocorrem os maiores deslocamentos, segundo a literatura.

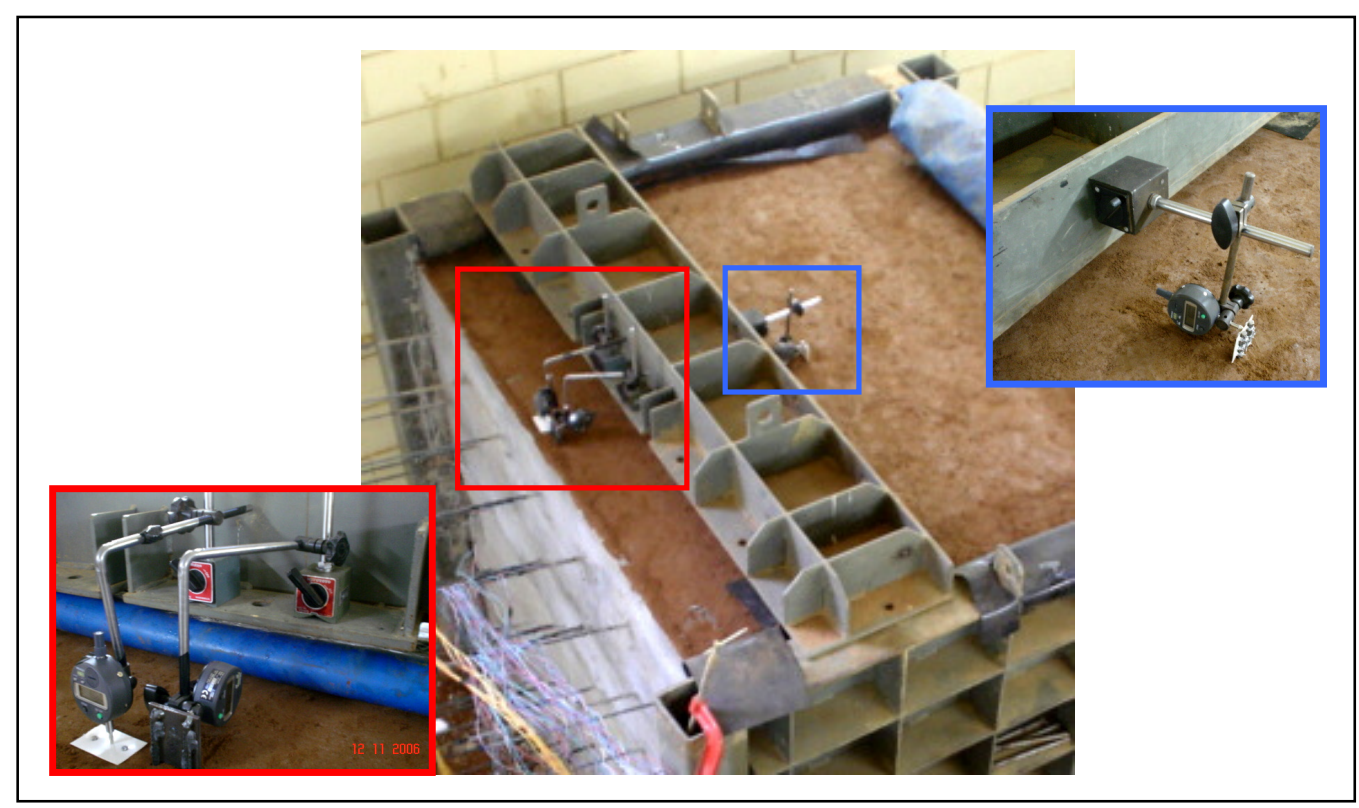

Figura 3.9 - Relógios comparadores utilizados para medição dos deslocamentos do protótipo durante a construção.

Após o término da construção, os deslocamentos horizontais foram medidos com LVDT`s posicionados na seção vertical central, em seis alturas diferentes $(0,425 \mathrm{~m} ; 0,675 \mathrm{~m}$; $0,925 \mathrm{~m} ; 1,175 \mathrm{~m} ; 1,425 \mathrm{~m} ; 1,625 \mathrm{~m})$.

\subsection{Calibração do forno de microondas}

Durante o procedimento de compactação do solo, descrito no item 3.6, foi 
necessário utilizar um método rápido de determinação do teor de umidade do solo. Assim, o uso do método convencional via estufa era impraticável. Optou-se, portanto, pelo método do forno de microondas. Para tanto, determinou-se o tempo de aquecimento necessário para a secagem completa do solo utilizado nesta pesquisa. Adotaram-se o procedimento descrito na ASTM-D4643 (1993) e as contribuições de Nogueira et al. (1999).

O tempo de aquecimento do solo foi determinado através de ciclos de aquecimento de 1 a 2 minutos, com pesagem da amostra de solo entre os ciclos. Com isso, foi possível verificar o tempo necessário para que o solo apresentasse massa constante. Esse procedimento foi repetido em três amostras com teores de umidade diferentes: uma seca ao ar, uma úmida (acima do teor de umidade ótimo) e uma mistura das duas anteriores em partes iguais. Determinaram-se os teores de umidade também pelo método convencional (em estufa) para comparação com os resultados obtidos com o forno microondas. O tempo total de aquecimento no forno de microondas foi de 20 minutos, quando somados todos os ciclos. A Figura 3.10 apresenta os resultados obtidos no processo de calibração do forno microondas para o solo utilizado nesta pesquisa. A Tabela 3.2 apresenta os teores de umidade das amostras obtidos a partir do método convencional em estufa e do aquecimento no forno de microondas.

O tempo de aquecimento necessário para a secagem completa do solo utilizado nesta pesquisa é igual a dez minutos, em destaque na Figura 3.10. Contudo, a determinação do teor de umidade do solo durante o processo de compactação foi executada em ciclos menores que três minutos para evitar um sobreaquecimento do solo, que pode modificar a estrutura do mesmo, tornando falso o resultado desta determinação. 


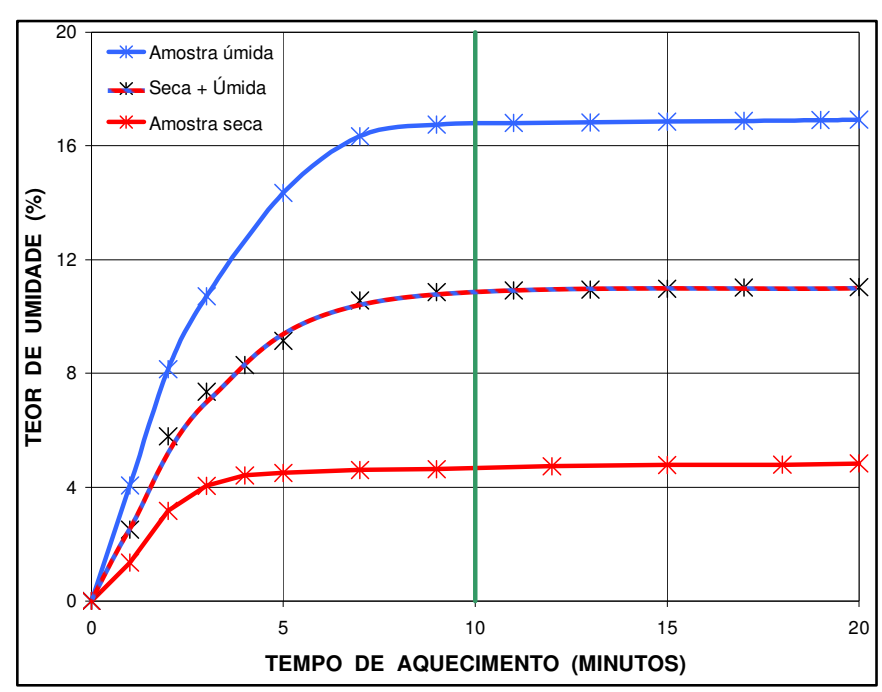

Figura 3.10 - Curvas de calibração do forno microondas para o solo utilizado nesta pesquisa.

Tabela 3.2 - Teores de umidade obtidos em estufa e no forno de microondas.

\begin{tabular}{ccc}
\hline Amostra & $\begin{array}{c}\text { Teor de umidade em } \\
\text { estufa }(\%)\end{array}$ & $\begin{array}{c}\text { Teor de umidade no } \\
\text { forno de microondas (\%) }\end{array}$ \\
\hline Seca ao ar & 4,4 & 4,8 \\
$\begin{array}{c}\text { Mistura (seca + úmida) } \\
\text { Úmida (acima do teor de } \\
\text { umidade ótimo) }\end{array}$ & 10,8 & 11,0 \\
\hline
\end{tabular}

\subsection{Compactação do solo}

A primeira etapa da construção do protótipo de solo grampeado foi o enchimento da caixa de ensaio com solo compactado. Para tanto, o solo foi inicialmente destorroado por peneiramento e, em seguida, separado em porções de cerca de $200 \mathrm{~kg}$ e acondicionado em bolsões (big bags). A determinação do teor de umidade por aquecimento no forno microondas foi executada para o solo de cada bolsão, imediatamente antes da sua utilização no processo de compactação. A correção de umidade foi feita em betoneira, garantindo a homogeneidade do solo em relação a esse parâmetro. 
Procedeu-se a compactação de duas formas diferentes, produzindo camadas com características distintas. Uma camada inferior foi executada através do lançamento do solo de cinco bolsões seguido da compactação com um compactador mecânico. Este procedimento foi repetido duas vezes e produziu uma camada de $430 \mathrm{~mm}$ de altura e grau de compactação (GC) médio de 99\%, em relação à Energia Normal de compactação. O grau de compactação foi determinado a partir do método do cilindro de cravação (Figura 3.11).

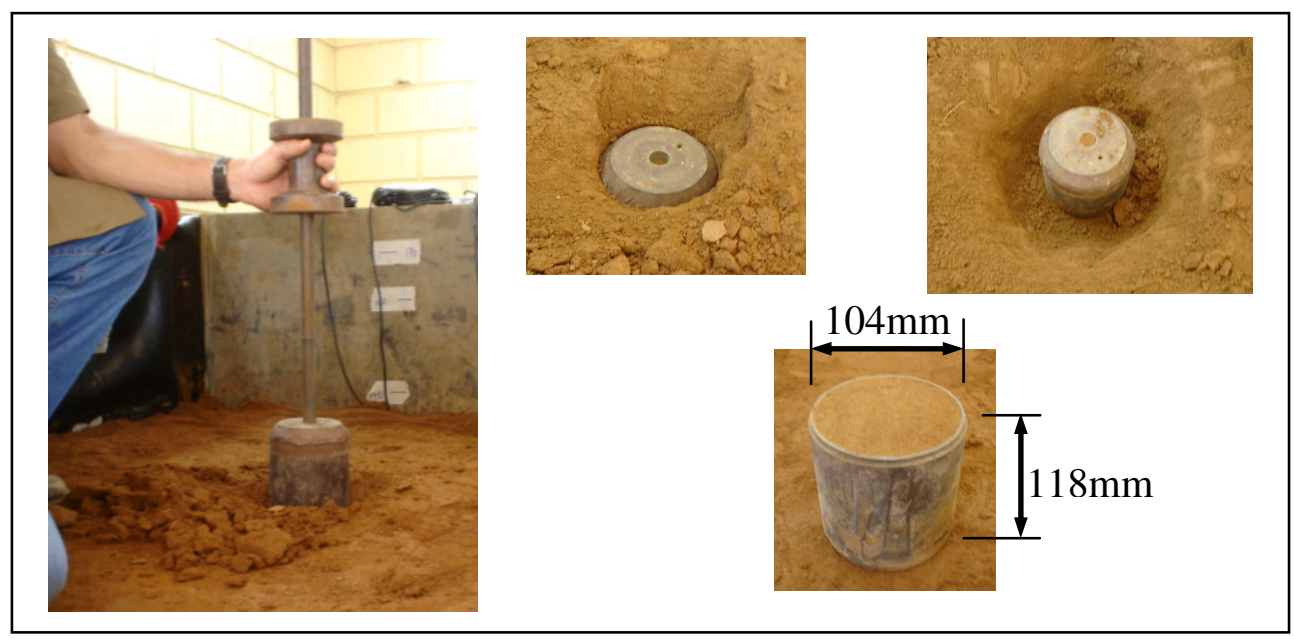

Figura 3.11 - Fotos ilustrativas do controle de compactação pelo método do cilindro de cravação.

As camadas restantes foram compactadas com soquete manual após o lançamento do solo de um bolsão (cerca de $200 \mathrm{~kg}$ ), com teor de umidade corrigido. O soquete manual utilizado possuía massa de $10 \mathrm{~kg}$ e altura de queda de cerca de $200 \mathrm{~mm}$. Este procedimento produziu camadas com cerca de $40 \mathrm{~mm}$ de altura e foi repetido até o enchimento completo da caixa de ensaio (Figura 3.12). Após a compactação de cinco camadas consecutivas, procediase um controle de compactação. Essa fase de compactação produziu uma camada com 1.300 mm de altura e grau de compactação e teor de umidade médios iguais a 88,5\% e 15,6\%, respectivamente. 

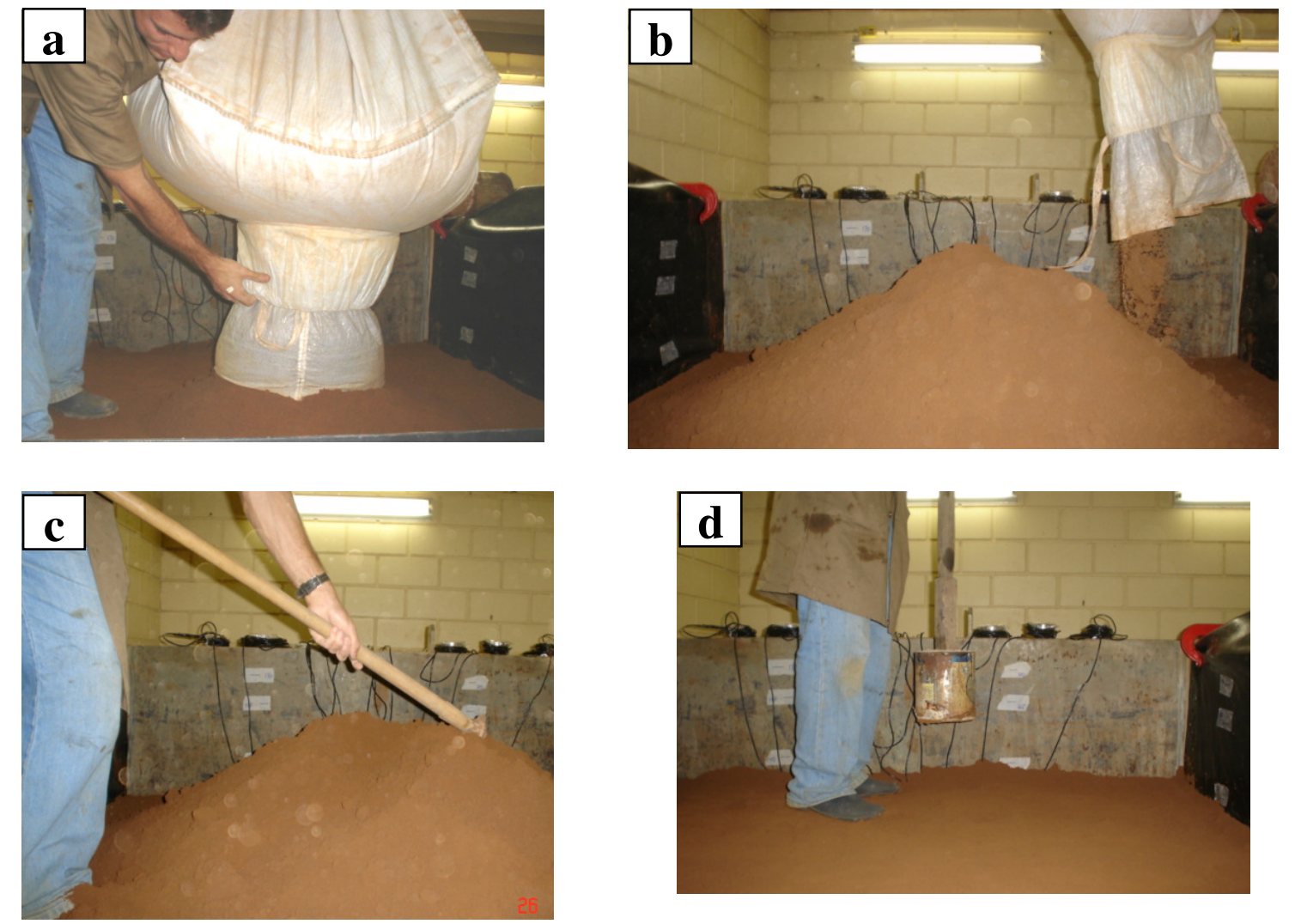

Figura 3.12 - Fotos ilustrativas do procedimento manual de compactação: a - antes do lançamento do solo; b - solo lançado; c - espalhamento manual com enxada; d - compactação com soquete manual.

O procedimento de compactação resultou, portanto, em um maciço de solo com duas camadas distintas: uma camada inferior, mais compacta, e uma superior, menos compacta. A Figura 3.13 apresenta a seção vertical representativa das camadas do maciço de solo compactado, juntamente com a representação dos grampos a serem executados. 


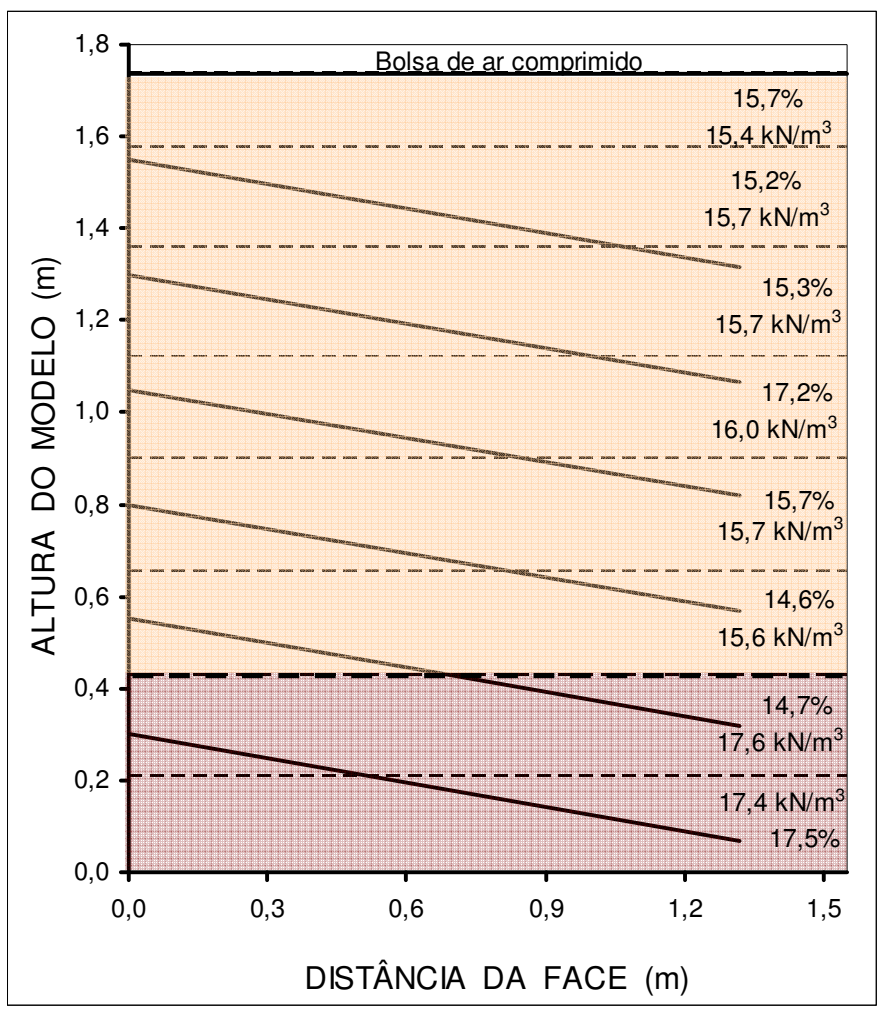

Figura 3.13 - Camadas do maciço de solo compactado utilizado para a construção do protótipo de solo grampeado.

\subsection{Execução do solo grampeado}

A execução do protótipo de solo grampeado reproduziu a prática comum em obras desse tipo: escavação, instalação dos grampos e execução da face. A face, contudo, foi concebida apenas para reduzir as perdas de umidade do maciço de solo exposto, antes e após a execução dos grampos.

A remoção sucessiva dos segmentos de madeira da face da caixa de ensaio simulou cada etapa de escavação. O solo permaneceu estável após cada etapa de escavação (Figura 3.14). Imediatamente após a remoção de um segmento de madeira da face aplicou-se uma pintura com a calda de cimento no solo exposto, para reduzir as perdas de umidade. 


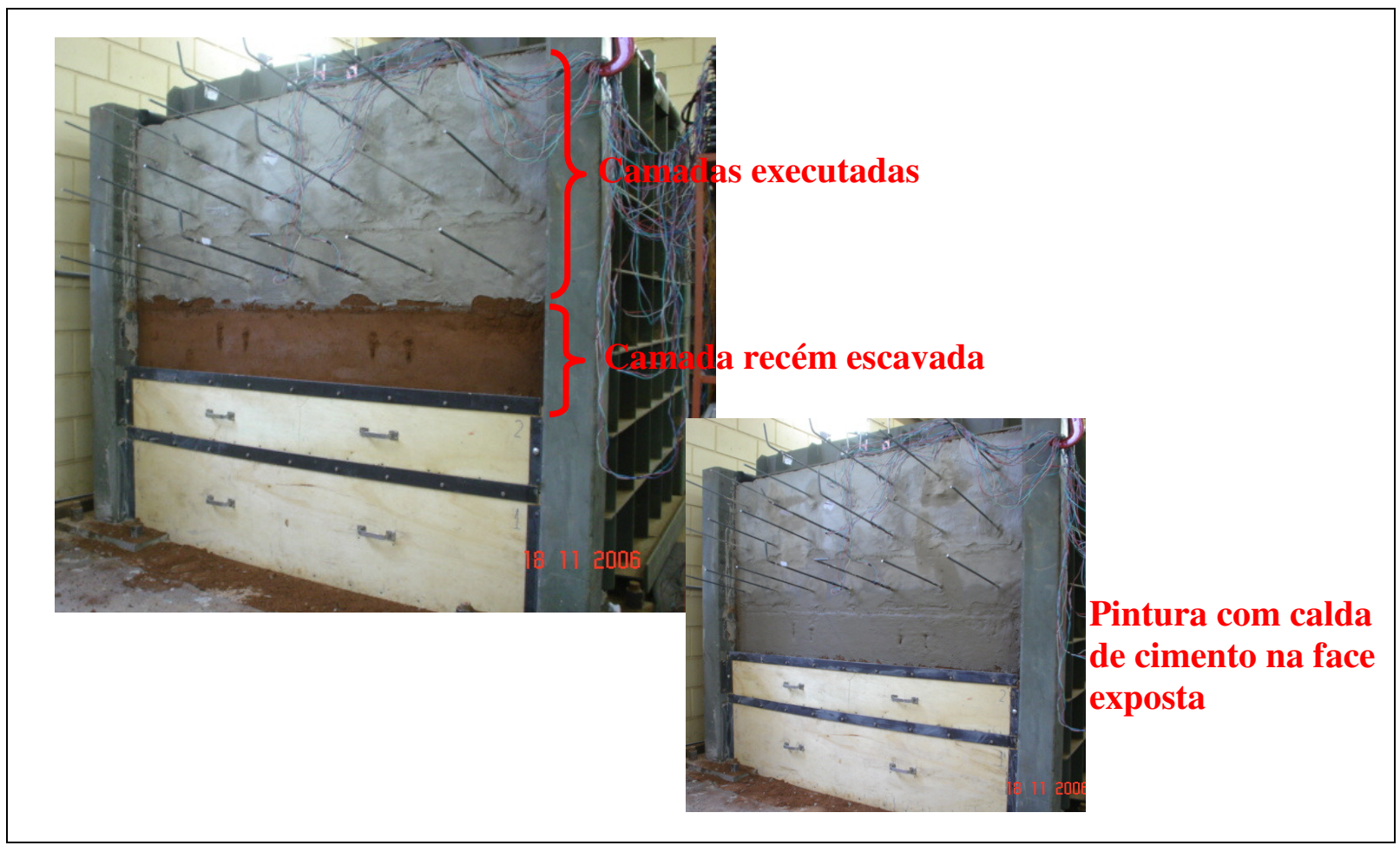

Figura 3.14 - Simulação do processo de escavação do maciço de solo através da remoção de um segmento da face de madeira.

A instalação dos grampos consistiu na perfuração do maciço de solo com trado manual de 25,4 mm de diâmetro, seguida da introdução da calda de cimento no furo e da barra de aço. A perfuração foi conduzida com inclinação de $10^{\circ} \mathrm{com}$ a horizontal. Introduziu-se a calda de cimento no furo sob ação da gravidade e por meio de um tubo de plástico (Figura 3.15), do fundo para a abertura do furo, para garantir que toda sua extensão fosse preenchida. A calda de cimento apresentou boa trabalhabiliade até duas horas após o seu preparo, tempo suficiente para a execução de uma linha de grampos. Introduziram-se as barras de aço nos furos imediatamente após o preenchimento com a calda de cimento, como verificado na Figura 3.15, onde o operador insere a barra de aço do grampo 2-2 enquanto o furo do grampo 2-3 é preenchido. Dois centralizadores instalados em cada barra de aço garantiram um recobrimento homogêneo $(9,5 \mathrm{~mm})$ de calda de cimento. 


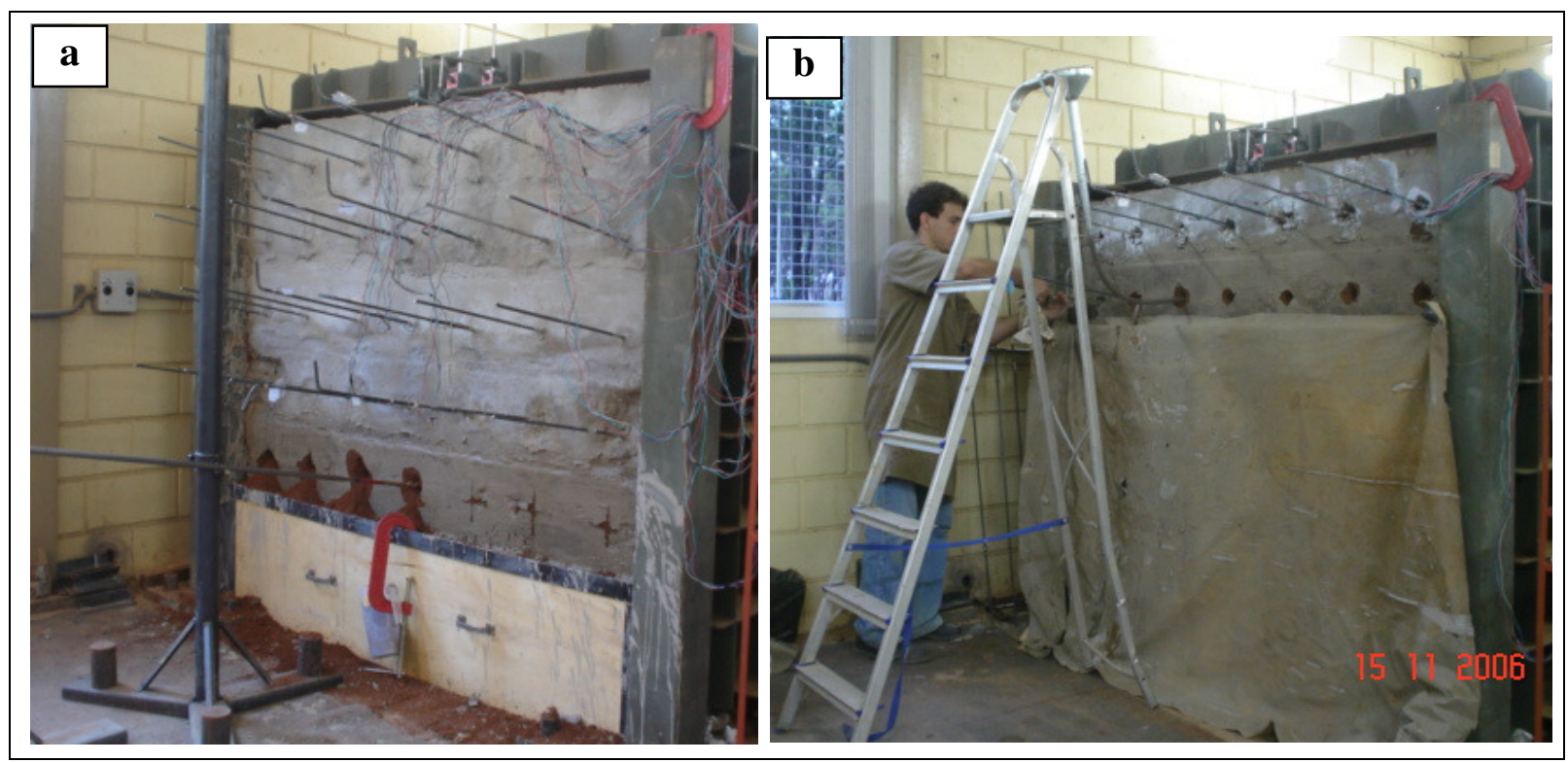

Figura 3.15 - Instalação dos grampos: a - perfuração com trado manual; b - preenchimento do furo com calda de cimento, por gravidade.

Após a execução de cada linha de grampos a face recebeu uma nova pintura com calda de cimento, com o mesmo propósito de reduzir a perda de umidade do maciço de solo e, de forma secundária, conter pequenas erosões superficiais.

\subsection{Aplicação de sobrecarga}

Aplicou-se uma sobrecarga de $50 \mathrm{kPa}$ após o término da construção do protótipo de solo pregado, com tempo suficiente para aquisição de resistência da calda de cimento. A sobrecarga foi aplicada com a utilização de uma bolsa de ar comprimido e com a reação da tampa da caixa de ensaio. Adaptou-se uma montagem de geomembranas de PVC com graxa entre elas na interface entre o solo e a bolsa inflável, de forma semelhante ao que foi feito nas paredes laterais da caixa de ensaio, para reduzir a influência da bolsa inflável nos deslocamentos do solo. O propósito da aplicação da sobrecarga foi simular a execução de outra obra na superfície do protótipo, levando a um acréscimo de tensões no solo contido. 


\subsection{Ensaios de arrancamento}

Realizaram-se ensaios de arrancamento em grampos previamente definidos após a aplicação da sobrecarga (50 kPa) e com velocidade média de $2,3 \mathrm{kN} / \mathrm{min}$. Os referidos ensaios consistiram na aplicação de uma força de tração por um macaco hidráulico com as medidas de deslocamento do grampo por um relógio comparador e de forças por uma célula de carga. $\mathrm{O}$ conjunto foi montado sobre um pórtico metálico rígido fixado ao chão.

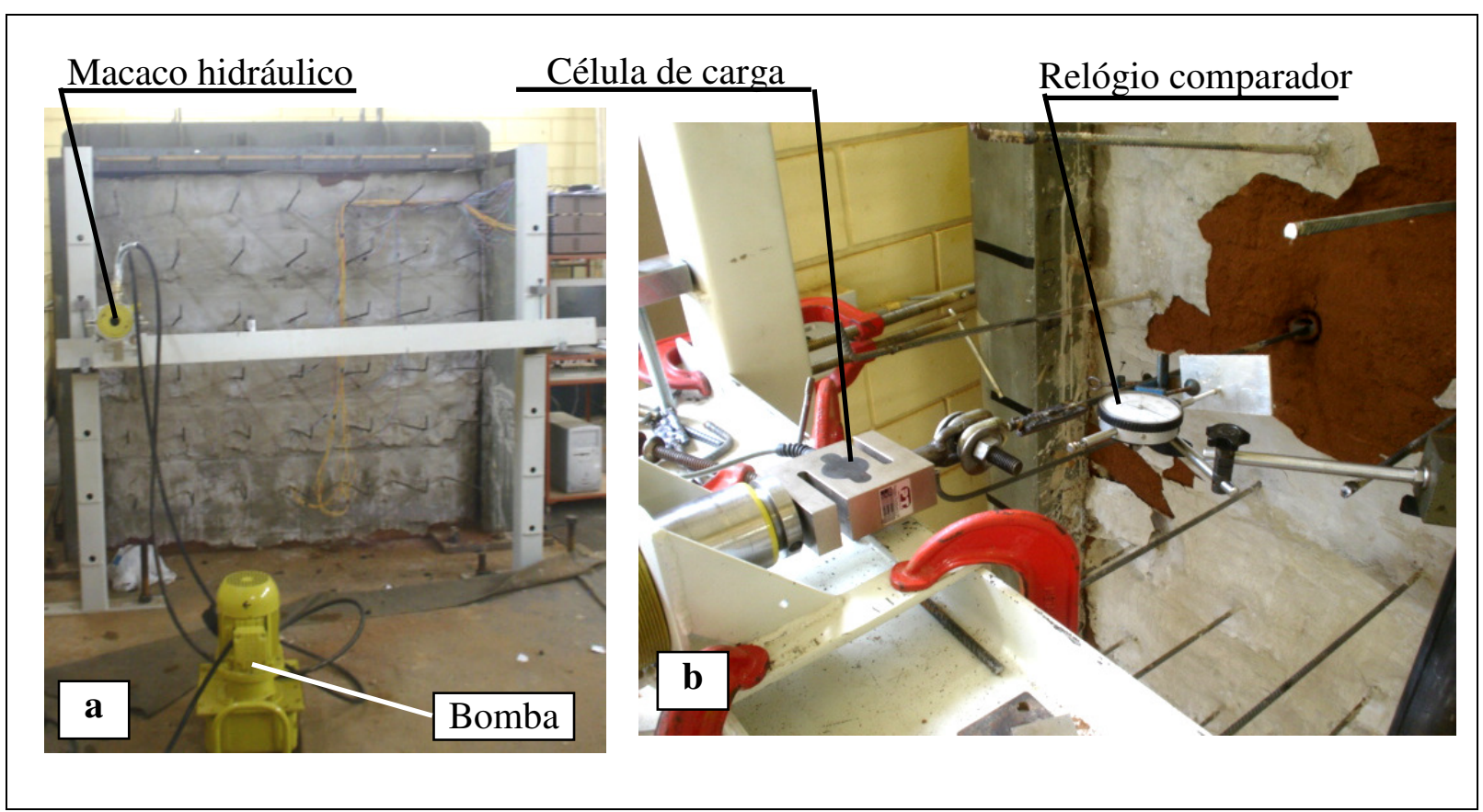

Figura 3.16 - Equipamentos utilizados nos ensaios de arrancamento. a - vista geral. b - vista detalhada.

Os ensaios consistiram na aplicação de dois ciclos de carregamento consecutivos.

Adotou-se esta metodologia devido a restrições no curso máximo do relógio comparador utilizado $(50 \mathrm{~mm})$. Os grampos submetidos aos ensaios de arrancamento foram extraídos completamente após a execução de todos os ensaios. A extração dos grampos foi realizada com o objetivo de verificar a redistribuição dos esforços no interior do maciço de solo, bem como avaliar a integridade física dos grampos. A Figura 3.17 apresenta uma visão geral do 
equipamento utilizado para a extração completa dos grampos.

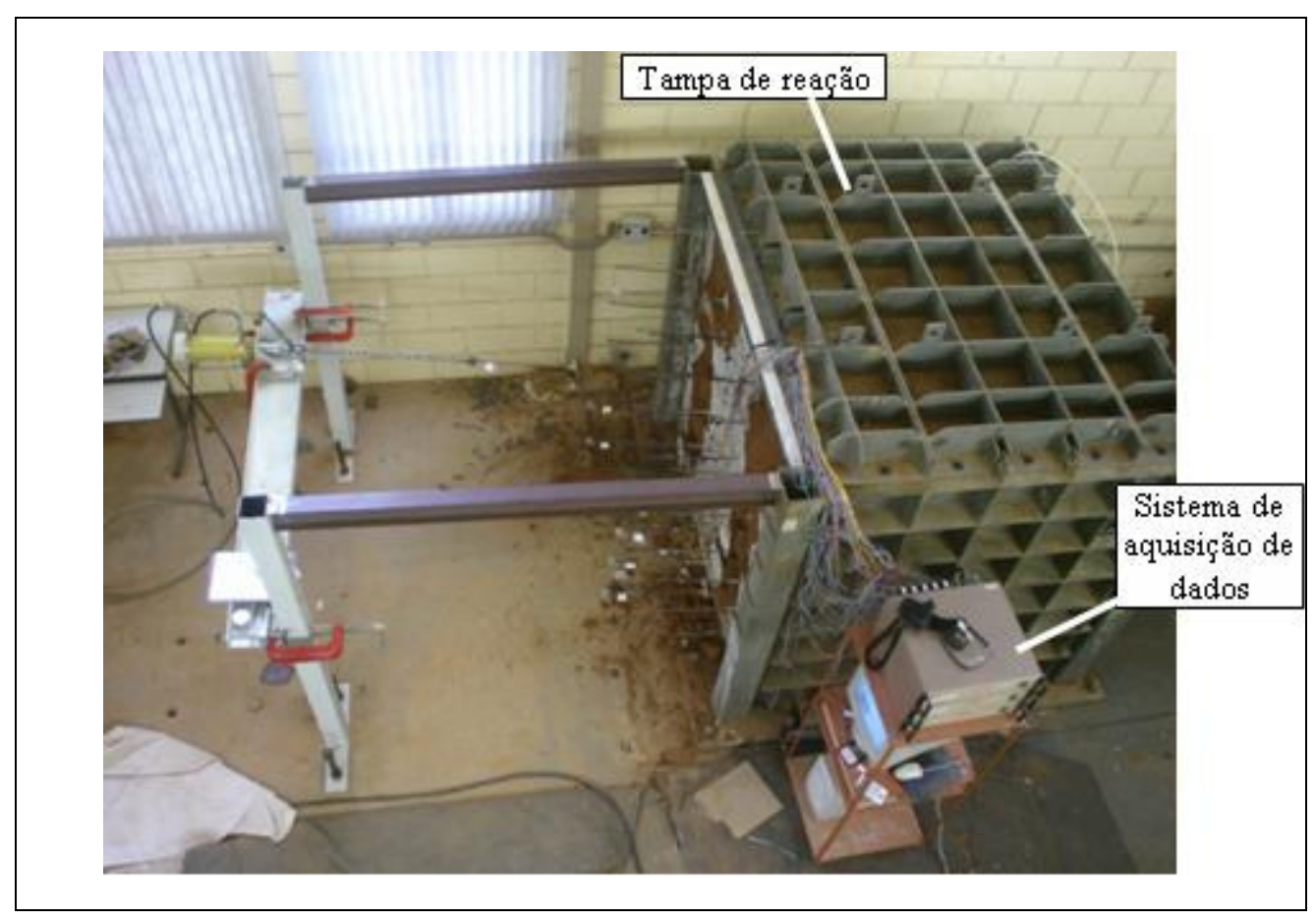

Figura 3.17 - Adaptação dos equipamentos utilizados nos ensaios de arrancamento para a extração completa dos grampos.

Ao final da extração completa de 11 grampos, previamente escolhidos, procederam-se ensaios de arrancamento em três grampos instrumentados, que ainda não haviam sido submetidos aos ensaios de arrancamento. Esta segunda etapa de ensaios de arrancamento visa verificar a evolução das solicitações ao longo dos grampos, ao longo dos ensaios. 


\section{Capítulo 4 - Apresentação e Análise dos Resultados}

Este capítulo mostra os resultados obtidos nesta pesquisa, os quais são apresentados e analisados em dois itens diferentes: ensaios de arrancamento e comportamento do protótipo. O item referente aos ensaios de arrancamento apresenta os resultados obtidos nestes ensaios, com destaque para aqueles realizados nos grampos instrumentados com extensômetros elétricos, bem como algumas considerações em relação à extração completa dos grampos. O comportamento do protótipo de solo grampeado é apresentado em termos de deslocamentos do solo e evolução das forças nos grampos.

Optou-se por apresentar os resultados de acordo com a importância dos objetivos apresentados no Capítulo 1. Desta forma, é dado maior destaque aos ensaios de arrancamento, em detrimento da ordem cronológica da pesquisa que, evidentemente, foi iniciada com a construção do protótipo e verificação dos deslocamentos e das forças nos grampos.

\subsection{Ensaios de arrancamento}

Os ensaios de arrancamento foram executados em 14 grampos (colunas $\mathrm{C}_{2}$ e $\mathrm{C}_{6} \mathrm{e}$ 
grampos 4-4, 6-4 e 6-5). Os grampos 4-4, 6-4 e 6-5 foram instrumentados com strain gages e submetidos aos ensaios de arrancamento após os grampos das colunas $\mathrm{C}_{2}$ e $\mathrm{C}_{6}$, não instrumentados. A Figura 4.1 apresenta os resultados obtidos nos ensaios de arrancamento, com os dois ciclos de carregamento.

A execução de ensaios de arrancamento em dois ciclos de carregamento apresentou-se como uma forma aceitável para simular ensaios que atingiriam maiores deslocamentos dos grampos. Optou-se pelos ensaios em dois ciclos devido a limitações do curso máximo do equipamento de medição dos deslocamentos. As curvas referentes ao segundo ciclo ajustaram-se perfeitamente às curvas do primeiro ciclo, exceto nos grampos 1-2 e 4-4. O ensaio de arrancamento do grampo 2-2 apresenta-se com três ciclos de carregamento, pois houve uma falha executiva do ensaio no segundo ciclo. Por este motivo, o carregamento foi suspenso e reiniciado em um terceiro ciclo.

A resistência ao cisalhamento da interface solo-grampo foi determinada a partir da Equação 3. A força de arrancamento apresentada na Equação 3 foi obtida a partir dos valores de pico das curvas força de arrancamento x deslocamento dos grampos. Para os grampos inseridos na camada superior (linhas $\mathrm{L}_{1}, \mathrm{~L}_{2}, \mathrm{~L}_{3}, \mathrm{~L}_{4}$ e $\mathrm{L}_{5}$ ) o valor médio da resistência ao cisalhamento de interface $\left(\mathrm{q}_{\mathrm{s}}\right)$ foi de $141,0 \mathrm{kPa}$ e para os grampos da linha $\mathrm{L}_{6}$ foi igual a 154,7 kPa. Essa divisão é justificada pelo fato dos grampos da linha $\mathrm{L}_{6}$ estarem completamente inseridos na camada inferior, mais compacta. A Tabela 4.1 apresenta um resumo dos resultados obtidos nos ensaios de arrancamento. A Tabela 4.1 também apresenta a resistência ao cisalhamento de interface residual $\left(\mathrm{q}_{70 \mathrm{~mm}}\right)$, considerada com $70 \mathrm{~mm}$ de deslocamento do grampo, além da relação entre $\mathrm{q}_{\mathrm{s}}$ e $\mathrm{q}_{70 \mathrm{~mm}}$. $\mathrm{O}$ valor médio dessa relação foi 2,38 e para $\mathrm{q}_{70 \mathrm{~mm}}$ foi encontrado um valor médio de $61,7 \mathrm{kPa}$, relativos a todos os ensaios. 

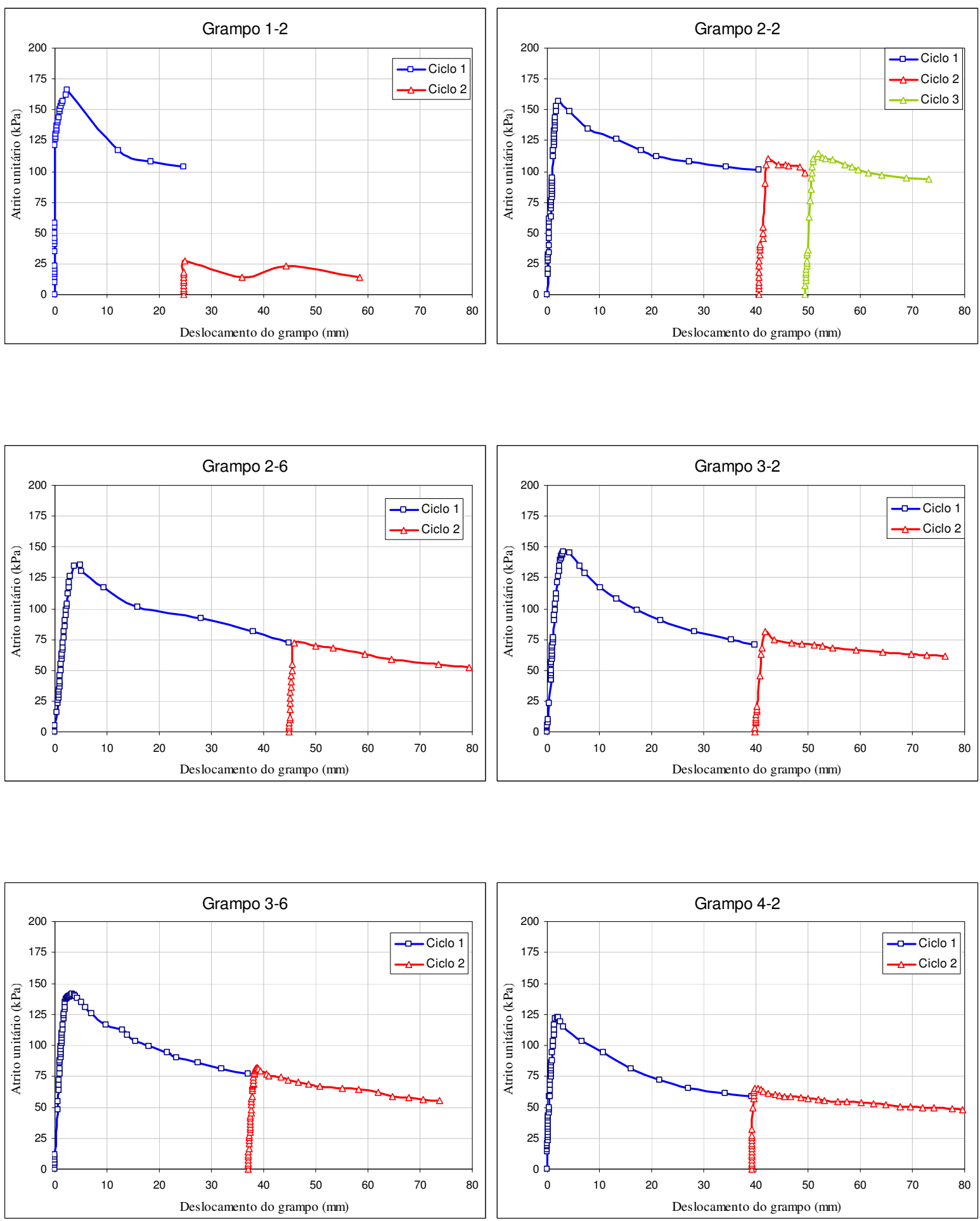

Figura 4.1 - Resultados dos ensaios de arrancamento executados nesta pesquisa. 

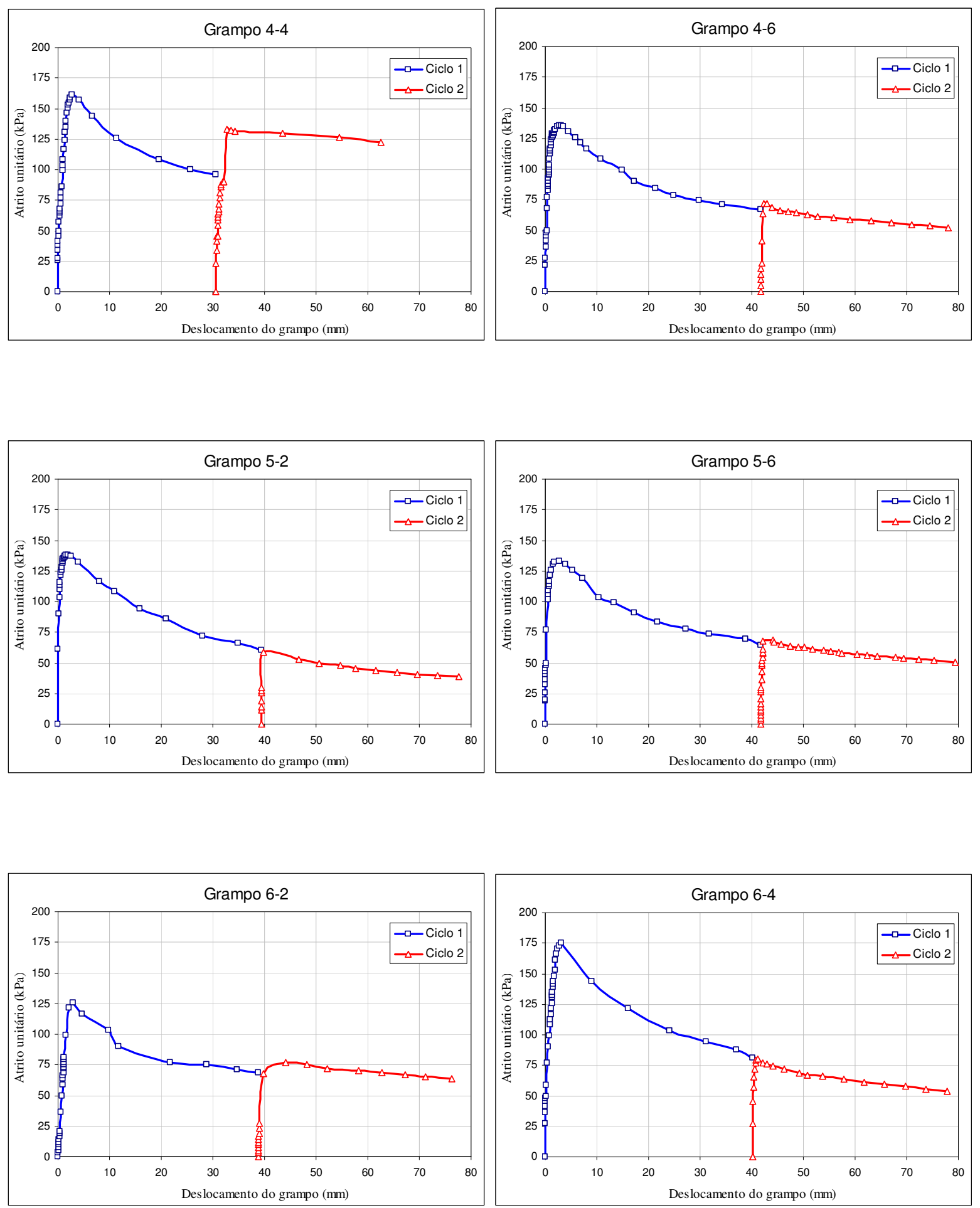

Figura 4.1 - Resultados dos ensaios de arrancamento executados nesta pesquisa (continuação). 

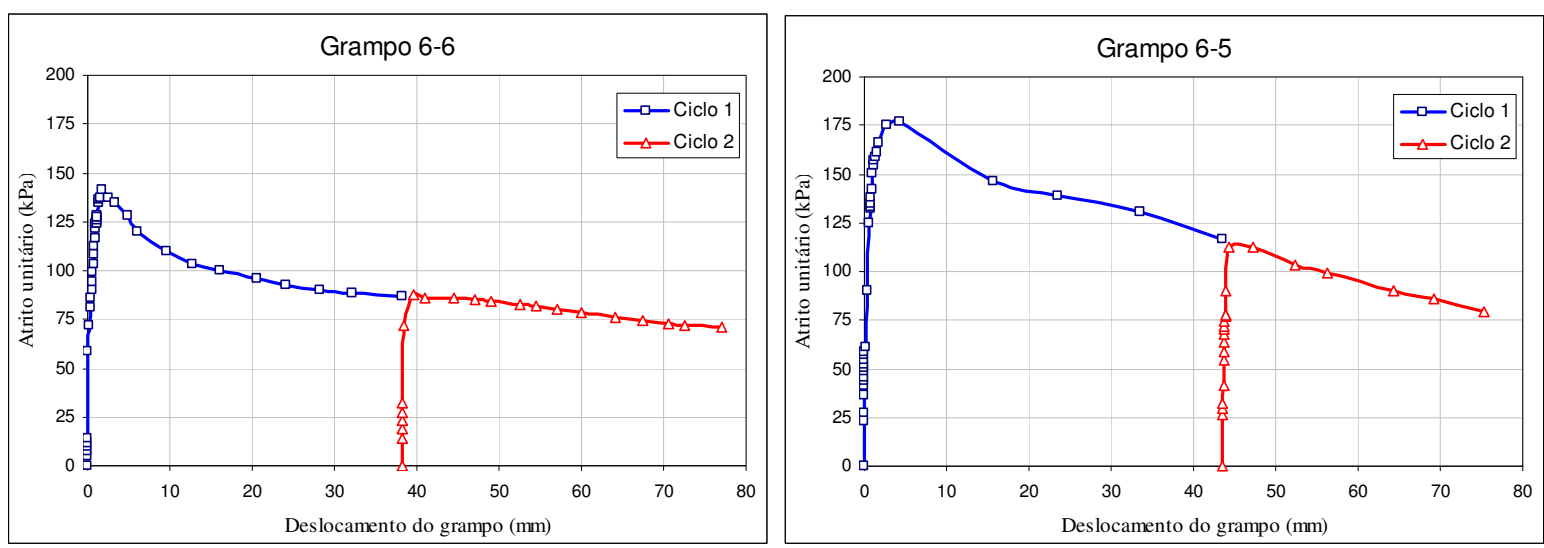

Figura 4.1 - Resultados dos ensaios de arrancamento executados nesta pesquisa (continuação).

Tabela 4.1 - Resultados dos ensaios de arrancamento.

\begin{tabular}{ccccccc}
\hline Ensaio $\mathrm{N}^{\mathrm{o}}$ & Grampo & $\begin{array}{c}\mathrm{T}_{\text {máx }} \\
(\mathrm{kN})\end{array}$ & $\begin{array}{c}\text { Deslocamento } \\
(\mathrm{mm})\end{array}$ & $\begin{array}{c}\mathrm{q}_{\mathrm{s}} \\
(\mathrm{kPa})\end{array}$ & $\begin{array}{c}\mathrm{q}_{70 \mathrm{~mm}} \\
(\mathrm{kPa})\end{array}$ & $\begin{array}{c}\mathrm{q}_{\mathrm{s}} \\
\mathrm{q}_{70 \mathrm{~mm}}\end{array}$ \\
\hline 1 & $1-2$ & 18,6 & 2,41 & 166,0 & $---*$ & $---*$ \\
2 & $2-2$ & 17,6 & 2,22 & 157,1 & 93,8 & 1,67 \\
3 & $2-6$ & 15,1 & 4,87 & 135,2 & 56,1 & 2,41 \\
4 & $3-2$ & 16,3 & 3,18 & 145,9 & 63,4 & 2,30 \\
5 & $3-6$ & 15,8 & 3,38 & 140,9 & 56,3 & 2,50 \\
6 & $4-2$ & 13,7 & 2,13 & 122,5 & 50,9 & 2,41 \\
7 & $4-4 * *$ & 18,1 & 2,78 & 161,7 & $---*$ & $---{ }^{*}$ \\
8 & $4-6$ & 15,2 & 2,71 & 135,9 & 54,5 & 2,49 \\
9 & $5-2$ & 15,5 & 1,58 & 138,3 & 39,3 & 3,52 \\
10 & $5-6$ & 14,9 & 2,79 & 133,0 & 53,6 & 2,48 \\
11 & $6-2$ & 14,1 & 2,85 & 125,8 & 65,2 & 1,93 \\
12 & $6-4$ & 19,6 & 3,15 & 175,1 & 57,5 & 3,04 \\
13 & $6-5 * *$ & 19,8 & 4,32 & 176,8 & 85,7 & 2,06 \\
14 & $6-6 * *$ & 15,8 & 1,86 & 141,0 & 73,2 & 1,93 \\
\hline
\end{tabular}

Nota: $\mathrm{T}_{\operatorname{máx}}=$ força de arrancamento máxima durante o ensaio; Deslocamento $=$ deslocamento do grampo para atingir a força de arrancamento máxima; $\mathrm{q}_{\mathrm{s}}=$ resistência ao cisalhamento da interface solo-grampo; $\mathrm{q}_{70 \mathrm{~mm}}=$ resistência ao cisalhamento da interface solo-grampo residual, tomada para um deslocamento do grampo igual a $70 \mathrm{~mm}$.

* Estes ensaios não atingiram $70 \mathrm{~mm}$ de deslocamento do grampo.

** Grampos instrumentados com extensômetros elétricos submetidos aos ensaios de arrancamento. 
De forma geral, a resistência ao cisalhamento de interface dos grampos inseridos na camada inferior apresentou-se cerca de $10 \%$ maior que aquela para os grampos da camada superior, menos compacta. Porém, esta afirmação só é verdadeira quando considerados os valores médios. Quando todos os valores são analisados, esta tendência não pôde ser verificada, como visualizado na Tabela 4.1. Assim, não pôde ser constatado um incremento expressivo na resistência ao cisalhamento de interface devido ao grau de compactação do solo.

O valor médio da resistência ao cisalhamento de interface é $144,7 \mathrm{kPa}$, com coeficiente de variação de 13\%, quando considerados todos os grampos submetidos ao arrancamento. A dispersão dos valores obtidos nos ensaios de arrancamento apresentou-se dentro de um intervalo satisfatório. Porém, chama-se atenção para obras reais, onde o controle das condições de contorno (tipo e condições do solo e a geometria da obra, por exemplo) é mais complexo e, por este motivo, pode haver uma maior dispersão dos valores de resistência ao cisalhamento de interface.

Os deslocamentos necessários para a mobilização total da resistência ao cisalhamento de interface (pico da curva força de arrancamento x deslocamento do grampo) foram pequenos, da ordem de 2 a $6 \mathrm{~mm}$, com valor médio igual a 3,08 $\mathrm{mm}$. Este valor corresponde a $0,24 \%$ do comprimento do grampo.

Byrne et al. (1998) apresenta faixas de valores de resistência ao cisalhamento de interface para vários tipos de solo, em grampos executados por meio de perfuração associada à calda de cimento (Tabela 4.2). Apesar de não trazer valores correspondentes ao solo utilizado na pesquisa (areia argilosa), pode-se fazer uma previsão aproximada da resistência ao cisalhamento de interface utilizando outros solos. Verifica-se na Tabela 4.2 que os valores de resistência ao cisalhamento de interface para solos arenosos variam de $50 \mathrm{kPa}$ (areia 
siltosa) a $240 \mathrm{kPa}$ (areia siltosa muito densa) e entre 100 e $200 \mathrm{kPa}$ para argilas arenosas. O valor médio da resistência ao cisalhamento de interface obtido para os grampos utilizados nesta pesquisa $(144,7 \mathrm{kPa})$ encontra-se no intervalo de variação sugerido por Byrne et al. (1998).

Tabela 4.2 - Valores da resistência ao cisalhamento da interface solo-grampo (adaptado de BYRNE et al., 1998).

\begin{tabular}{ccc}
\hline Tipo de solo & Descrição do solo & $\begin{array}{c}\text { Resistência ao } \\
\text { cisalhamento de } \\
\text { interface }(\mathrm{kPa})\end{array}$ \\
\hline & Silte não plástico & $20-30$ \\
Silte arenoso & $50-75$ \\
Solos não & Areia siltosa & $50-75$ \\
& Areia medianamente compacta & $50-75$ \\
& Areia siltosa densa & $80-100$ \\
Solos & Areia siltosa muito densa & $120-240$ \\
coesivos & Loess & $25-75$ \\
& Silte argiloso & $40-100$ \\
\hline
\end{tabular}

A Figura 4.2 apresenta os valores de resistência ao cisalhamento de interface em função do parâmetro $\mathrm{z} / \mathrm{H}$, onde $\mathrm{z}$ é a profundidade do grampo na face e $\mathrm{H}$ é a altura total do protótipo. São apresentados apenas os resultados obtidos para os grampos inseridos na camada superior, menos compacta. Embora trabalhos como o FRENCH NATIONAL RESEARCH PROJECT CLOUTERRE (1991) tenham sugerido que os valores de resistência ao cisalhamento de interface sejam constantes ao longo da profundidade do muro. Isto não foi observado neste caso, como se pode notar da análise dos resultados apresentados na Figura 4.2. A explicação para se admitir valores de atrito unitário constantes com a profundidade tem sido creditada à dilatância do solo. O solo superficial pode dilatar-se, no entanto, à medida 
que a profundidade cresce, crescem também as tensões confinantes que restringem a dilatância a ponto de impedi-la abaixo de certa profundidade. A dilatância impedida gera um acréscimo de tensão confinante na superfície do grampo. O decréscimo da dilatância com a profundidade seria então compensado pelo acréscimo da tensão confinante sobre o grampo.

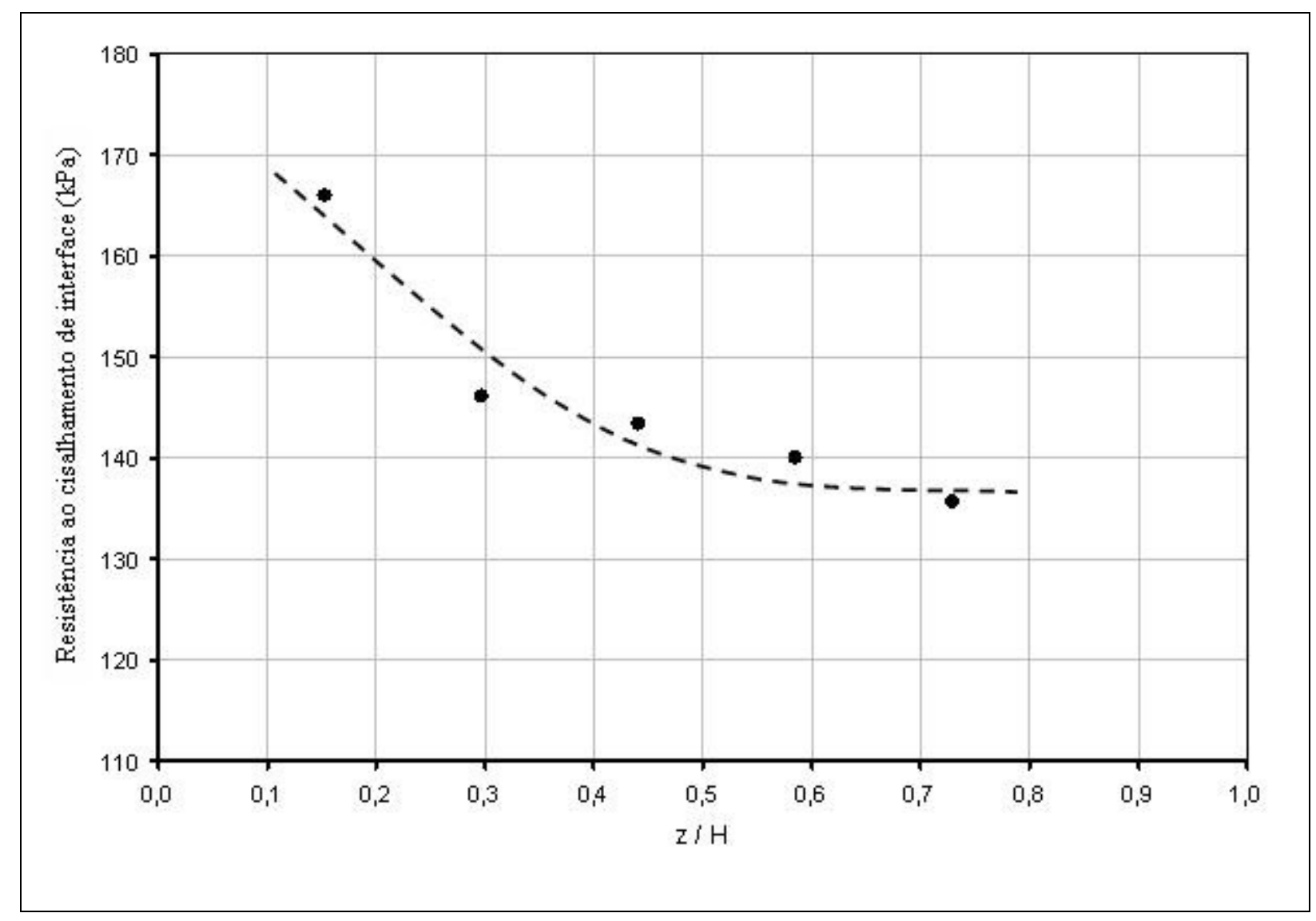

Figura 4.2 - Resistência ao cisalhamento de interface versus profundidade dos grampos em valores absolutos e médios.

Este é um argumento simplista, pois ao se escavar a face, permite-se a expansão do maciço, que caminha para o campo ativo. Isto gera uma intensa redistribuição das tensões que se intensifica no entorno da superfície hipotética de ruptura. Como as tensões verticais são afetadas pela intensidade do arqueamento, suas ações sobre os grampos dependem também dos fatores que determinam a ação do arqueamento, entre eles citam-se os parâmetros de resistência do solo e de suas evoluções com os deslocamentos do maciço. Disto resulta 
uma enorme dificuldade de se prever com segurança valores de atrito unitário em maciços de solo grampeado.

\subsubsection{Ensaios de arrancamento nos grampos instrumentados}

Os ensaios de arrancamento nos grampos instrumentados (4-4, 6-4 e 6-5) permitiram verificar a distribuição das forças nos grampos ao longo do ensaio. A Tabela 4.3 e a Figura 4.3 apresentam os resultados que demonstram a evolução da força de arrancamento durante o ensaio, com quatro níveis de carregamento referentes ao atrito lateral dos grampos $\left(25,50,75\right.$ e $100 \%$ da resistência ao cisalhamento de interface, $\left.\mathrm{q}_{\mathrm{s}}\right)$.

Os grampos instrumentados submetidos aos ensaios de arrancamento apresentaram comportamentos semelhantes no tocante à mobilização das forças de arrancamento. Para os quatro níveis de carregamento, as forças nos grampos mostraram-se máximas na face, com a redução dos valores ao longo dos grampos. A mobilização da resistência ao cisalhamento de interface ocorreu, portanto, a partir da face do protótipo.

A análise das curvas para os vários níveis de carregamento em um único grampo permitiu constatar que um comprimento maior do grampo foi solicitado à medida que o carregamento aumentava. A extrapolação das curvas referentes a $100 \%$ da força de arrancamento demonstrou que o comprimento total dos grampos foi solicitado quase integralmente. Verificando a extrapolação destas curvas, percebe-se que o grampo 4-4 foi solicitado em cerca de $88 \%$ do seu comprimento e os grampos 6-4 e 6-5, em cerca de $96 \%$. 
Tabela 4.3 - Força nos grampos para os quatro níveis de carregamento analisados nesta pesquisa.

\begin{tabular}{ccccc}
\hline $\begin{array}{c}\text { Nível de } \\
\text { carregamento (\%) }\end{array}$ & $\begin{array}{c}\text { Distância da } \\
\text { face }(\mathrm{m})\end{array}$ & Grampo 4-4 & Grampo 6-4 & Grampo 6-5 \\
\hline \multirow{4}{*}{25} & 0 & 4,52 & 4,91 & 4,96 \\
& 0,2 & $*$ & $*$ & 2,38 \\
& 0,4 & 1,85 & 2,63 & 1,76 \\
& 0,65 & 0,16 & 0,53 & 0,77 \\
& 0,95 & $*$ & $*$ & $*$ \\
\hline 50 & 0 & 9,05 & 9,82 & 9,92 \\
& 0,2 & $*$ & $*$ & $*$ \\
& 0,4 & 4,78 & 6,45 & 6,67 \\
& 0,65 & 0,96 & 3,28 & 2,28 \\
75 & 0,95 & $*$ & 0,53 & $*$ \\
\hline \multirow{3}{*}{5} & 0 & 13,57 & 14,73 & 14,88 \\
& 0,2 & $*$ & $*$ & $*$ \\
& 0,4 & 8,69 & 10,36 & 11,25 \\
& 0,65 & 3,77 & 6,51 & 7,42 \\
& 0,95 & 0,27 & 2,87 & 1,06 \\
\hline \multirow{2}{*}{100} & 0 & 18,09 & 19,64 & 19,84 \\
& 0,2 & $*$ & $*$ & $*$ \\
& 0,4 & 12,77 & 14,58 & 14,69 \\
& 0,65 & 5,90 & 9,77 & 10,65 \\
& 0,95 & 1,56 & 4,68 & 4,23 \\
\hline
\end{tabular}

* As leituras destes extensômetros elétricos apresentaram-se incoerentes com a forma da curva. 


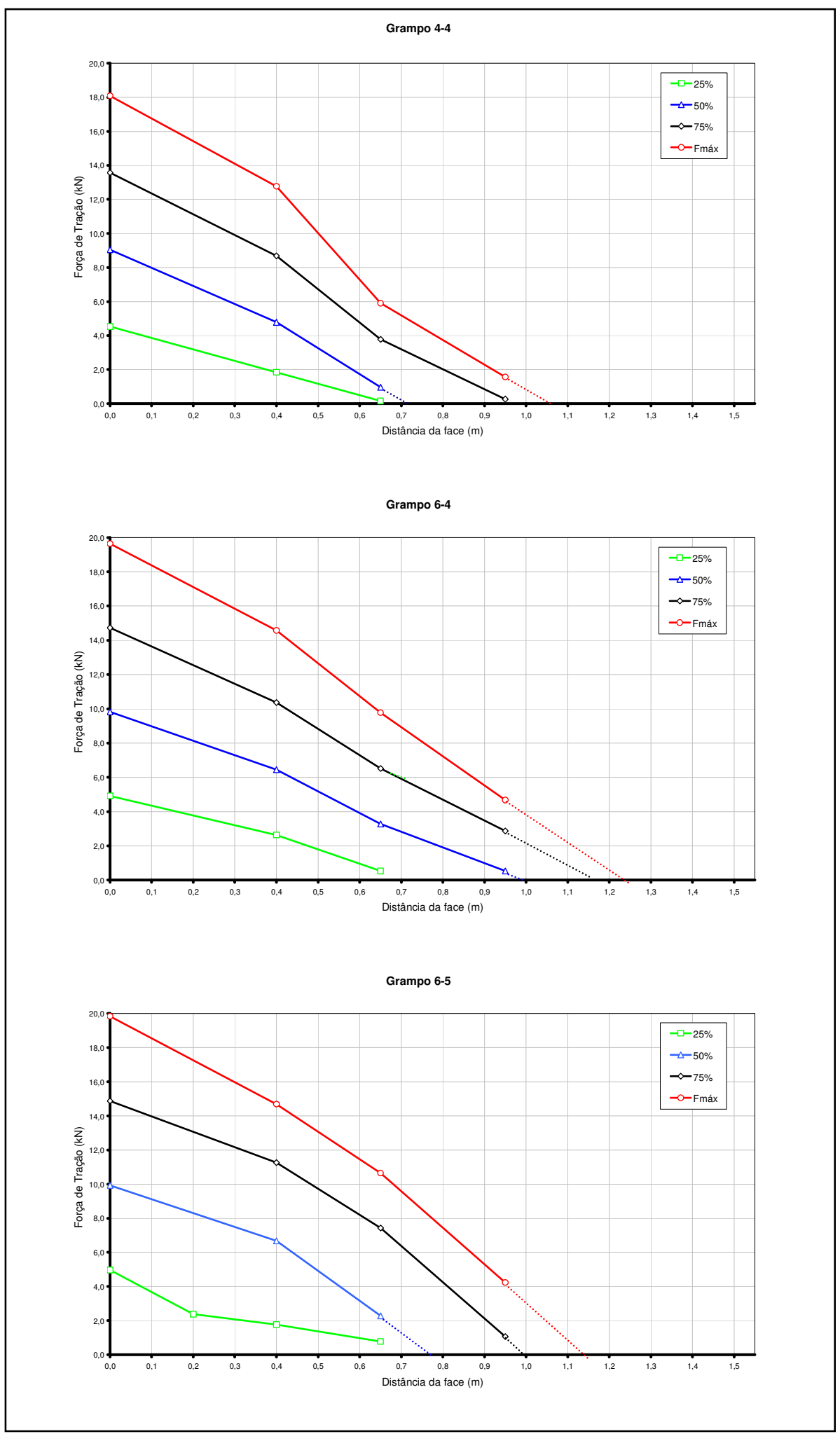

Figura 4.3 - Evolução do comprimento solicitado durante os ensaios de arrancamento executados nos grampos instrumentados (4-4, 6-4 e 6-5). Foram plotados quatro níveis de carregamento em relação à força de arrancamento. 


\subsubsection{Extração dos grampos}

A extração completa dos grampos não permitiu uma avaliação quantitativa precisa em relação ao comportamento do protótipo de solo grampeado. Os ensaios de arrancamento desfiguraram a face do protótipo, impossibilitando uma correta quantificação dos esforços devido à dificuldade em determinar o comprimento de contato solo-grampo existente. Contudo, a extração total dos grampos possibilitou uma análise qualitativa da redistribuição dos esforços bem como verificar o estado dos grampos em relação à sua execução.

Detectaram-se os maiores incrementos de força nos grampos superiores (linha $\mathrm{L}_{1}$ e $\mathrm{L}_{2}$ ), em pontos localizados próximos à face (até $400 \mathrm{~mm}$ desta). $\mathrm{O}$ protótipo permaneceu estável após a extração de todos os grampos previstos (colunas $\mathrm{C}_{2}$ e $\mathrm{C}_{6}$ ), indicando, possivelmente, que o projeto previu uma densidade de grampos com fator de segurança adequado.

A extração dos grampos permitiu verificar sua integridade. A Figura 4.4 mostra alguns exemplos de grampos extraídos. De forma geral, eles apresentaram-se íntegros, contudo, verificou-se a presença de alguns vazios na calda de cimento. Estes vazios não afetaram os valores de resistência ao cisalhamento de interface de maneira perceptível, pois não foi possível associar valores menores de $\mathrm{q}_{\mathrm{s}}$ aos grampos com vazios na calda de cimento. 

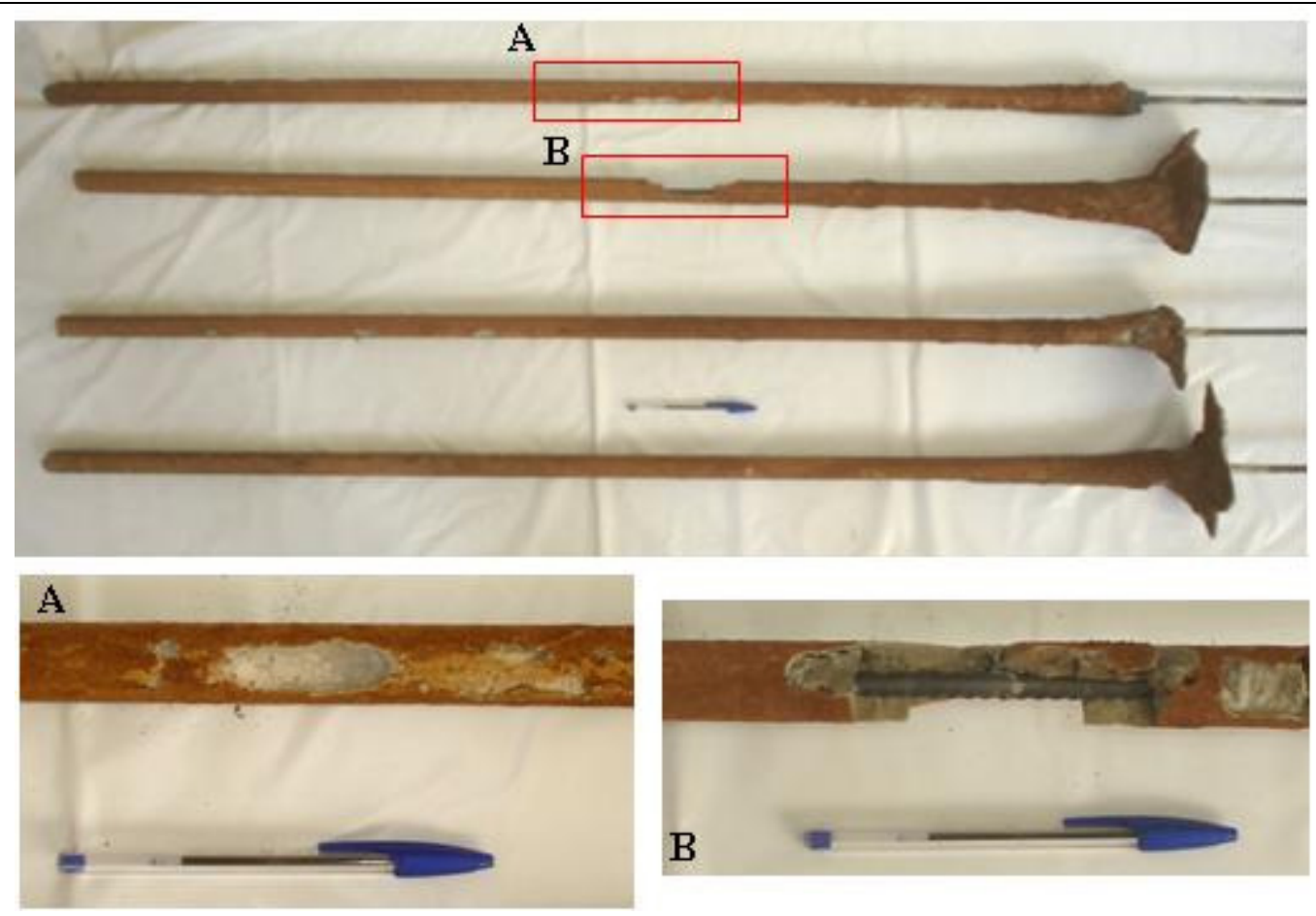

Figura 4.4 - Exemplos de grampos submetidos à extração completa.

\subsection{Comportamento do protótipo}

O protótipo de solo grampeado construído nesta pesquisa teve o seu comportamento avaliado antes da execução dos ensaios de arrancamento. Esta avaliação foi dividida em duas etapas distintas: durante e após o término da construção. O protótipo foi avaliado em termos de deslocamentos do solo e forças nos grampos, como apresentado a seguir.

\subsubsection{Deslocamentos do solo}

As medidas de deslocamento da face foram tomadas em dois momentos diferentes, durante e após a construção do protótipo de solo grampeado, com o uso de equipamentos diferentes para cada situação. 


\subsubsection{Deslocamentos do solo durante a construção do protótipo}

Segundo a literatura, os maiores deslocamentos do solo em obras de solo grampeado ocorrem na sua crista. Por este motivo, optou-se por medir os deslocamentos horizontal e vertical do solo em um ponto próximo à crista do protótipo, a $50 \mathrm{~mm}$ da face. De forma complementar, mediram-se os deslocamentos horizontais a 750mm da face. A evolução dos deslocamentos medidos nesta etapa é apresentada na Figura 4.5.

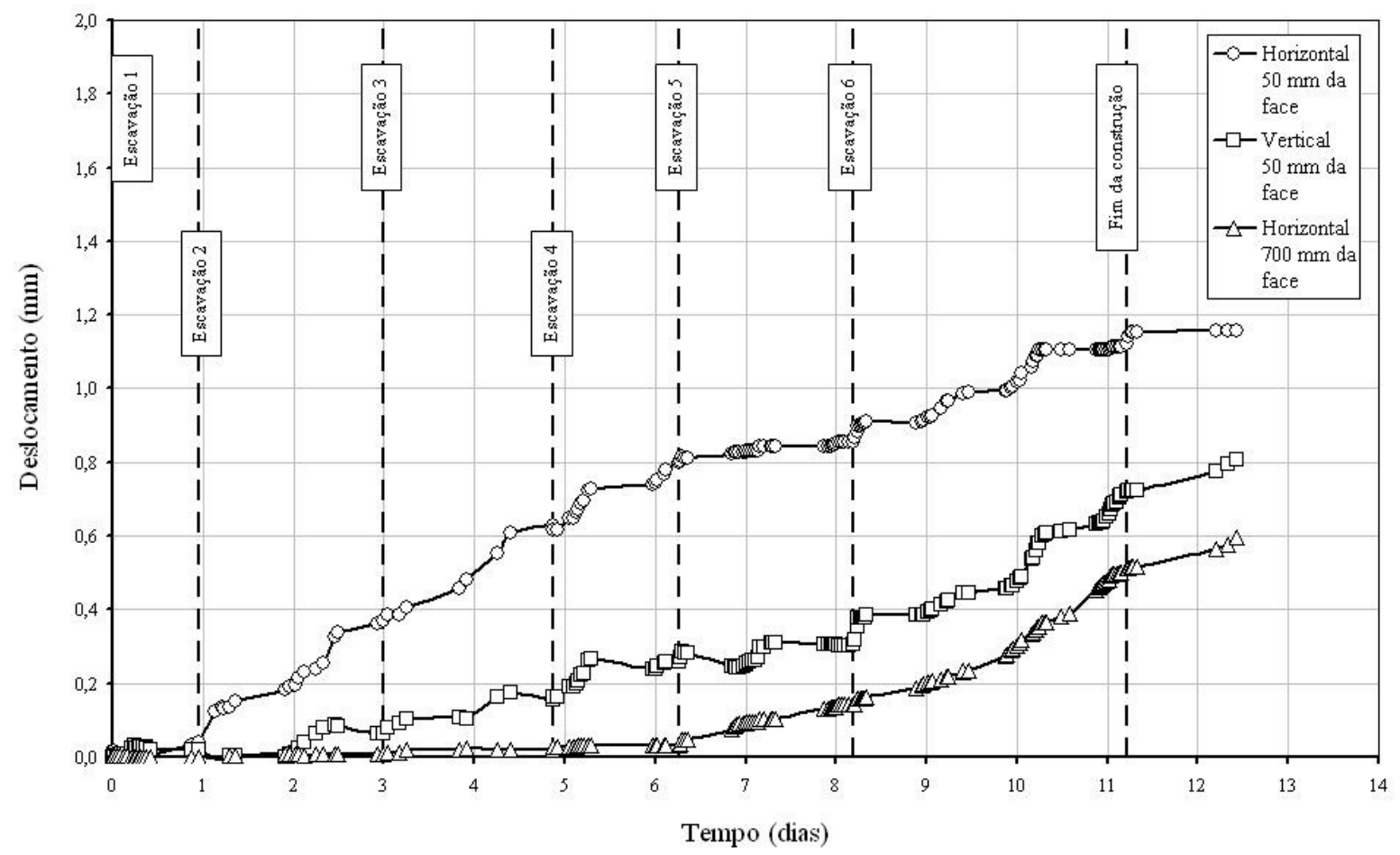

Figura 4.5 - Evolução dos deslocamentos medidos durante a construção do protótipo em solo grampeado.

A partir destes resultados determinaram-se as taxas de incremento dos deslocamentos de cada linha de grampo durante a sua execução, através da relação entre o deslocamento medido e o tempo de execução da respectiva linha de grampos. A Tabela 4.4 apresenta as taxas de incremento dos deslocamentos durante a execução de cada linha de 
grampos e o tempo necessário para a execução da mesma.

A execução da linha $\mathrm{L}_{1}$ provocou pequenos deslocamentos horizontais que atingiram pontos a $50 \mathrm{~mm}$ da face $(0,026 \mathrm{~mm})$. Verifica-se que a maior taxa de incremento dos deslocamentos horizontais nesse ponto ocorreu durante a execução da segunda linha $\left(\mathrm{L}_{2}\right)$ e foi igual a $0,161 \mathrm{~mm} /$ dia. A taxa de incremento dos deslocamentos horizontais em pontos a $50 \mathrm{~mm}$ da face reduziu-se até a linha $\mathrm{L}_{5}(0,030 \mathrm{~mm} / \mathrm{dia})$, atingindo um valor da ordem daquele medido na execução da linha $\mathrm{L}_{1}$. A execução da linha $\mathrm{L}_{6}$ impôs um aumento na taxa de incremento do deslocamento horizontal $(0,088 \mathrm{~mm} /$ dia $)$ devido à maior altura de escavação $(430 \mathrm{~mm}$ ) desta etapa. O deslocamento horizontal em pontos a $50 \mathrm{~mm}$ da face atingiu o valor de 1,123 mm imediatamente após o término da construção e 1,159 mm 29 horas depois deste momento.

Tabela 4.4 - Taxa média de incremento dos deslocamentos medidos (mm/dia).

\begin{tabular}{ccccc}
\hline Etapa & $\delta_{\mathrm{h} 50 \mathrm{~mm}}$ & $\delta_{\mathrm{v} 50 \mathrm{~mm}}$ & $\delta_{\mathrm{h} 750 \mathrm{~mm}}$ & $\begin{array}{c}\text { Tempo } \\
(\text { dias })\end{array}$ \\
\hline Linha L1 & 0,027 & 0,021 & 0,000 & 0,96 \\
Linha L2 & 0,161 & 0,022 & 0,002 & 2,04 \\
Linha L3 & 0,139 & 0,049 & 0,008 & 1,86 \\
Linha L4 & 0,123 & 0,075 & 0,009 & 1,39 \\
Linha L5 & 0,030 & 0,025 & 0,056 & 1,94 \\
Linha L6 & 0,088 & 0,137 & 0,123 & 3,02 \\
\hline
\end{tabular}

Nota: Linha $\mathrm{L}_{\mathrm{i}}=$ execução da linha de grampos de índice $\mathrm{i} ; \delta_{\mathrm{h} 50 \mathrm{~mm}}=$ taxa de incremento dos deslocamentos horizontais a $50 \mathrm{~mm}$ da face; $\delta_{\mathrm{v}} 50 \mathrm{~mm}=$ taxa de incremento dos deslocamentos verticais a $50 \mathrm{~mm}$ da face; $\delta_{\mathrm{h}} 750 \mathrm{~mm}=$ taxa de incremento dos deslocamentos horizontais a $750 \mathrm{~mm}$ da face; Tempo = tempo para a execução da etapa.

Os deslocamentos verticais a $50 \mathrm{~mm}$ da face apresentaram-se, de forma geral, com taxas de incremento crescentes, exceto pela execução da linha $\mathrm{L}_{5}$. A maior taxa de incremento foi verificada na execução da linha $\mathrm{L}_{6}(0,137 \mathrm{~mm} / \mathrm{dia})$. Contudo, é importante ressaltar que 
não deve ser feita uma comparação direta deste valor com os demais, obtidos para as outras linhas de grampos, devido a possuir uma profundidade de escavação diferente $(430 \mathrm{~mm})$. O deslocamento vertical a $50 \mathrm{~mm}$ da face atingiu $0,721 \mathrm{~mm}$ ao final da construção e $0,807 \mathrm{~mm}$ 29 horas depois.

Os deslocamentos horizontais a $750 \mathrm{~mm}$ da face apresentaram incrementos crescentes à medida que o protótipo foi construído. Entretanto, o início desses deslocamentos ocorreu, expressivamente, apenas a partir da execução da linha $\mathrm{L}_{5}$ de grampos. $\mathrm{O}$ valor máximo de deslocamento horizontal a $750 \mathrm{~mm}$ da face ocorreu durante a execução da linha $\mathrm{L}_{6}$ $(0,123 \mathrm{~mm} / \mathrm{dia})$, contudo, recorda-se que esta etapa foi executada com uma maior profundidade de escavação. Ao final da construção, o deslocamento horizontal a $750 \mathrm{~mm}$ da face atingiu $0,512 \mathrm{~mm}$ e $0,596 \mathrm{~mm} 29$ horas depois.

Devido ao método construtivo, com etapas sucessivas de escavação, era esperado que os maiores deslocamentos fossem horizontais e que ocorressem no topo das obras de solo grampeado, junto à face da contenção. O protótipo apresentou um comportamento esperado em relação aos deslocamentos medidos durante a sua construção, com os valores máximos de deslocamento medidos próximos à face e na direção horizontal. O deslocamento horizontal máximo na face corresponde a $0,07 \%$ da altura do protótipo. A estimativa inicial para este valor era de 0,1 a $0,4 \%$ da altura do muro segundo dados obtidos pelo Projeto Clouterre (1991) e Bruce e Jewell (1987). Apesar dos deslocamentos medidos no protótipo terem sido menores que as previsões da literatura, eles aproximaram-se muito do valor mínimo desse intervalo.

A comparação entre as leituras de deslocamento mostrou que os maiores valores ocorreram junto à face e na direção horizontal. Os deslocamentos horizontais a $750 \mathrm{~mm}$ da face foram observados, praticamente, somente após a quinta etapa de escavação e atingiram, 
no final da construção, cerca de $48 \%$ do deslocamento horizontal a $50 \mathrm{~mm}$ da face. Verificase, portanto, que é necessária uma profundidade de escavação maior para desencadear deslocamentos no solo em pontos mais distantes da face.

Ao final da construção, os deslocamentos verticais a $50 \mathrm{~mm}$ da face foram da ordem de $64 \%$ dos deslocamentos horizontais neste ponto.

\subsubsection{Deslocamentos do solo após a construção do protótipo}

Aplicou-se uma sobrecarga de $50 \mathrm{kPa}$ sobre o protótipo de solo grampeado após o término da construção. Esta sobrecarga foi aplicada através de uma bolsa inflável de ar comprimido e uma tampa de reação montadas sobre a superfície do protótipo. Nesta etapa, os deslocamentos horizontais foram medidos na seção central do protótipo, em seis níveis (alturas) diferentes, com a utilização de medidores de deslocamento elétricos (LVDT`s). A Figura 4.6 apresenta os deslocamentos horizontais medidos em quatro datas diferentes, 14, 17, 24 e 28 dias após o término da construção do protótipo e aplicação da sobrecarga. 


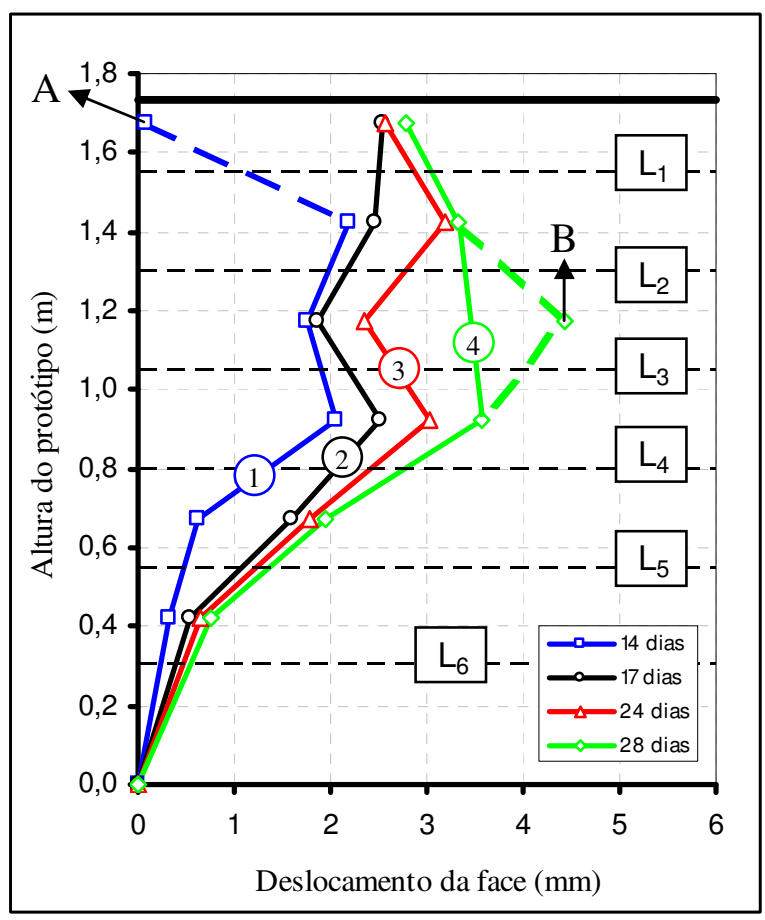

Figura 4.6 - Deslocamentos horizontais da face após a aplicação da sobrecarga (50 kPa).

Verifica-se na Figura 4.6 que dois pontos fogem ao padrão obtido nas demais curvas, A e B. Sugere-se que o ponto A deva ser desconsiderado da análise, pois apresenta um valor muito próximo de zero e incoerente com os deslocamentos medidos a essa altura $(1,425 \mathrm{~m})$ em outras datas. O ponto $\mathrm{B}$, por sua vez, também se apresenta fora dos padrões obtidos nas outras curvas, contudo, isso pode indicar uma interferência do sistema de aplicação de sobrecarga (bolsa de ar comprimido), fazendo com que os deslocamentos horizontais não sejam máximos no topo do protótipo.

Até o terceiro nível medido (0,925 m de altura) os deslocamentos horizontais da face mostraram-se proporcionais a altura do protótipo para as quatro curvas. Entretanto, a partir desse nível, o desenvolvimento de deslocamentos horizontais da face apresentou-se diferente em cada data de coleta de dados e não proporcionais a altura do protótipo.

As curvas referentes a 14, 17 e 24 dias após a aplicação da sobrecarga mostraramse semelhantes, na sua forma, até a altura de 1,425 m do protótipo, com um valor reduzido a 
1,175 m de altura, seguido de um valor mais elevado a 1,425 m de altura. Contudo, os valores máximos foram obtidos em alturas diferentes nessas três curvas.

A curva 1 (14 dias) apresenta o valor máximo com 1,425 m de altura (2,188 mm), A curva 2 (17 dias) apresentou o valor máximo próximo ao topo do protótipo $(1,675 \mathrm{~m})$ e igual a 2,540 mm. A curva 3 (24 dias) apresentou o deslocamento horizontal da face máximo a $1,425 \mathrm{~m}$ de altura e igual a $3,342 \mathrm{~mm}$.

A curva referente aos deslocamentos horizontais da face 28 dias após a aplicação da sobrecarga (curva 4) mostrou-se com um formato diferenciado das demais devido à leitura expressa pelo ponto B (Figura 4.6). Com a desconsideração do ponto B, verifica-se que os maiores deslocamentos horizontais ocorreram a $0,925 \mathrm{~m}$ de altura, seguido de valores menores para alturas maiores. Entretanto, o ponto B pode ser considerado e indica que o protótipo não obedeceu ao comportamento previsto na literatura, onde o deslocamento horizontal máximo se localiza no topo do protótipo, próximo à face. Esta variação pode ser devido à influência da bolsa inflável que reduz, por atrito, os deslocamentos na superfície do protótipo, apesar de ter recebido a montagem de geomembranas de PVC com graxa, conforme descrito no item 3.8 .

O deslocamento horizontal da face próximo ao topo teve um aumento pouco expressivo entre as curvas 2 (17 dias), 3 (24 dias) e 4 (28 dias), da ordem de 9,4\% entre os valores limites (17 e 28 dias). Verifica-se que os deslocamentos horizontais máximos, próximos ao topo e durante a construção do protótipo, transladaram para uma altura de cerca de $80 \%$ da altura do protótipo alguns dias após a aplicação da sobrecarga de $50 \mathrm{kPa}$. O deslocamento horizontal máximo atingiu em torno de $0,2 \%$ da altura do protótipo de solo grampeado 28 dias após a aplicação da sobrecarga. 


\subsubsection{Forças nos grampos}

A instalação de extensômetros elétricos (strain gages) nas barras de aço utilizadas como grampos permitiu verificar a evolução da força de tração durante a pesquisa. A coleta dos dados foi realizada durante a construção do protótipo de solo grampeado e após a aplicação da sobrecarga de $50 \mathrm{kPa}$, durante os ensaios de arrancamento. A Figura 4.7 apresenta seis exemplos ilustrativos da evolução da força de tração nos grampos instrumentados ao longo do tempo. São apresentados exemplos em todas as linhas de grampos e em strain gages posicionados a diferentes distâncias da face. Os pontos em destaques (pontos cheios) referem-se ao fim da construção do protótipo (ponto A) e ao momento da aplicação da sobrecarga de $50 \mathrm{kPa}$ (ponto B).

Verificou-se, de forma geral, que a força de tração nos grampos aumentou durante a construção do protótipo e, sobretudo, com a aplicação da sobrecarga. Apenas os grampos da linha $\mathrm{L}_{6}$ não mostraram o mesmo comportamento. Verifica-se que a aplicação da sobrecarga não alterou, de forma efetiva, a força de tração nos grampos da linha $\mathrm{L}_{6}$. As demais linhas de grampos tiveram comportamentos distintos durante e após a construção do protótipo.
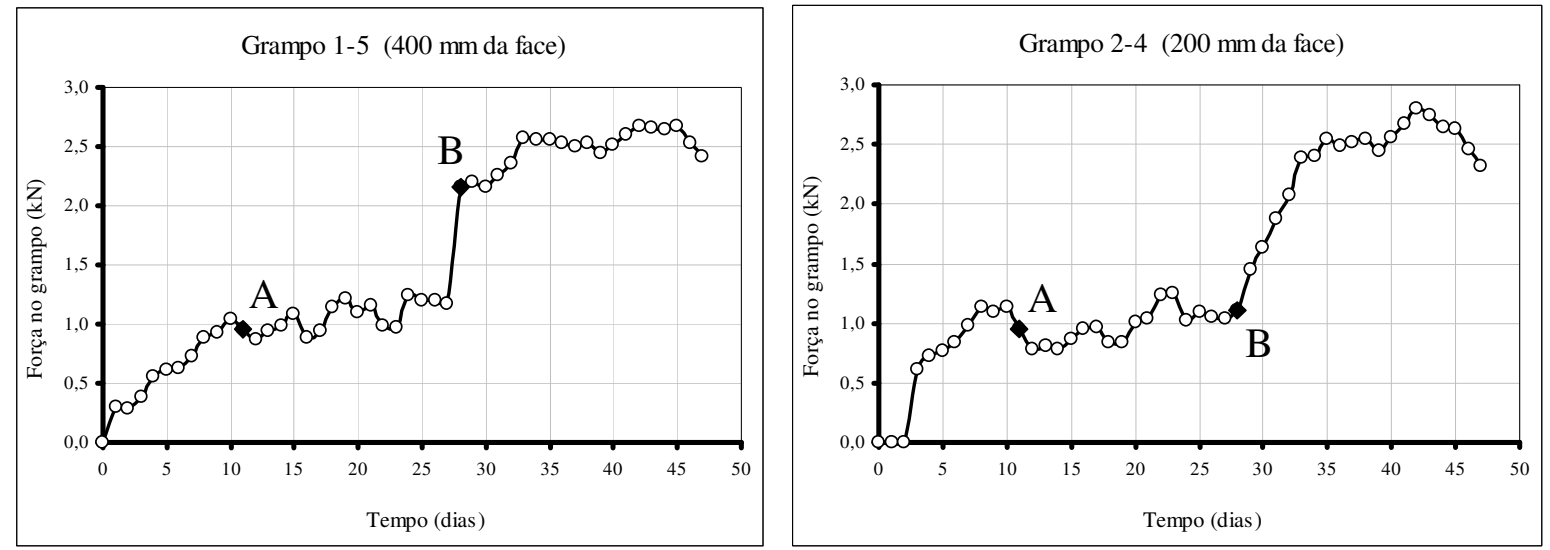

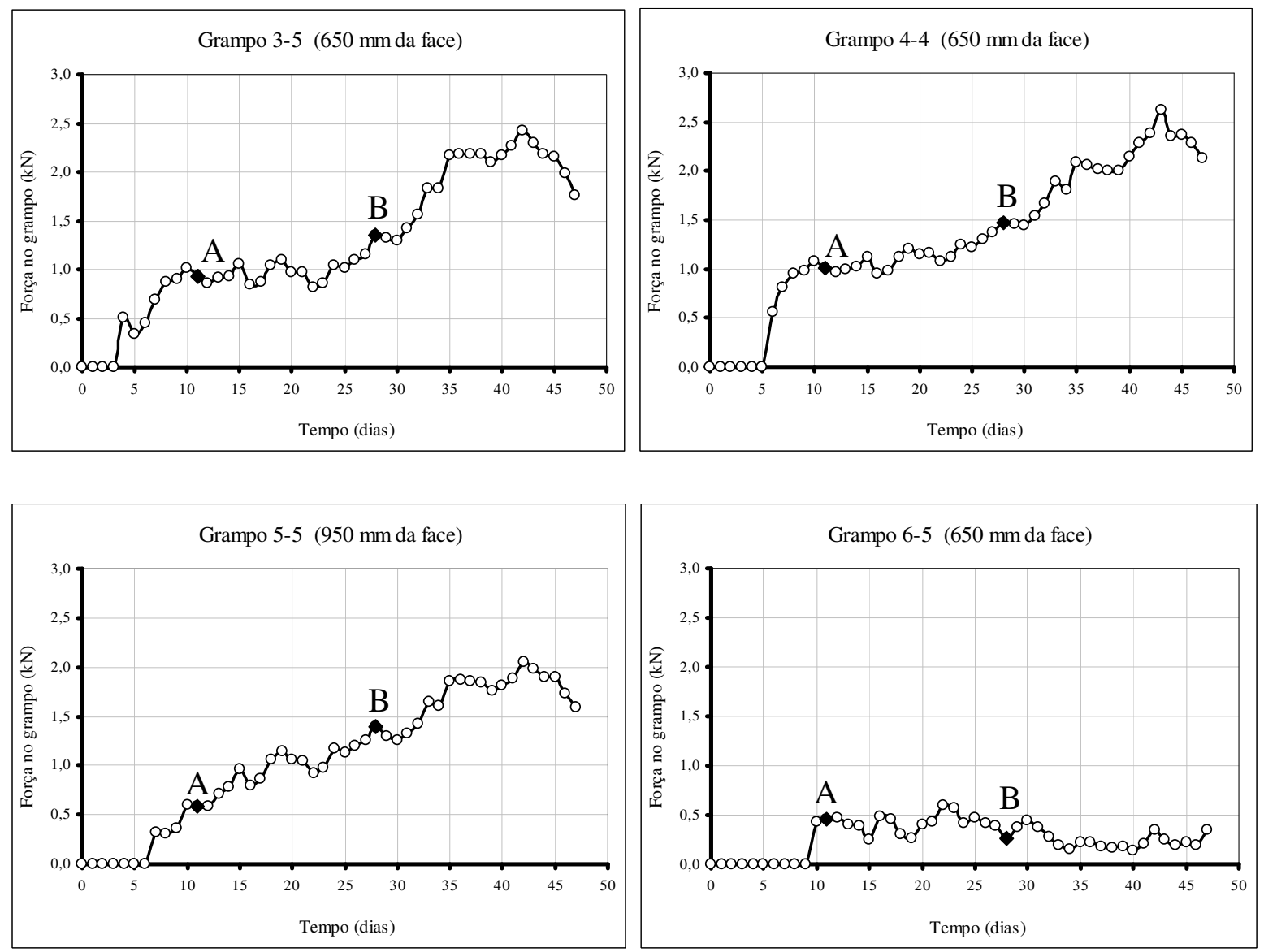

Figura 4.7 - Gráficos típicos da evolução da força de tração nos grampos instrumentados.

A força de tração nos grampos da linha $L_{1}$ aumentou uniformemente durante a construção do protótipo e permaneceu em um patamar praticamente constante até a aplicação da sobrecarga, quando atingiu outro patamar, cerca de $125 \%$ mais elevado. As linhas $\mathrm{L}_{2}$ e $\mathrm{L}_{3}$ apresentaram um comportamento semelhante ao verificado na linha $\mathrm{L}_{1}$, diferindo apenas na velocidade com que a força de tração aumentou durante a construção do protótipo e após a aplicação da sobrecarga, mais lenta para a linha $\mathrm{L}_{3}$.

A força de tração nos grampos das linhas $\mathrm{L}_{4}$ e $\mathrm{L}_{5}$ aumentaram ainda mais lentamente durante estas duas etapas (durante a construção do protótipo e após a aplicação da sobrecarga). Verifica-se, na linha $\mathrm{L}_{5}$, que a força de tração nos grampos continuou aumentando no período entre o fim da construção e a aplicação da sobrecarga como resposta 
aos deslocamentos do solo que continuaram a ocorrer após o término da construção. A linha $\mathrm{L}_{6}$ apresentou um comportamento singular, pois foi pouco solicitada e não teve incrementos significativos após a aplicação da sobrecarga.

O incremento de força nos grampos, provocado pela aplicação da sobrecarga na superfície do protótipo, apresenta-se claro para as linhas $\mathrm{L}_{1}, \mathrm{~L}_{2}, \mathrm{~L}_{3}, \mathrm{~L}_{4} \mathrm{e} \mathrm{L}_{5}$. A linha $\mathrm{L}_{6}$ não sofreu influência efetiva da aplicação da sobrecarga no que diz respeito às forças nos grampos.

Foram executados ensaios de arrancamento em grampos adjacentes aos grampos instrumentados. Não se verificaram variações das forças nos grampos instrumentados devido a tais ensaios, executados após a aplicação da sobrecarga. Esse comportamento está associado à resistência residual nos grampos submetidos ao ensaio de arrancamento. A referida resistência apresentou valores maiores que o máximo valor de força medido nos grampos instrumentados durante o estudo, mesmo após a aplicação da sobrecarga. Assim, os grampos submetidos aos ensaios de arrancamento permaneceram com resistência suficiente para continuarem absorvendo esforços resultantes da geometria do protótipo.

\subsubsection{Sugestão de uma superfície potencial de ruptura}

A análise dos valores de força máxima os grampos foi dividida em dois momentos: ao término da construção e após a aplicação da sobrecarga. Foram tomadas as leituras dos strain gages nestes dois momentos. A linha que une os pontos de máxima solicitação nos grampos aproxima-se da superfície potencial de ruptura do maciço reforçado, portanto, foram sugeridas superfícies potenciais de ruptura para as duas situações analisadas (Figura 4.8). 
Fim da construção

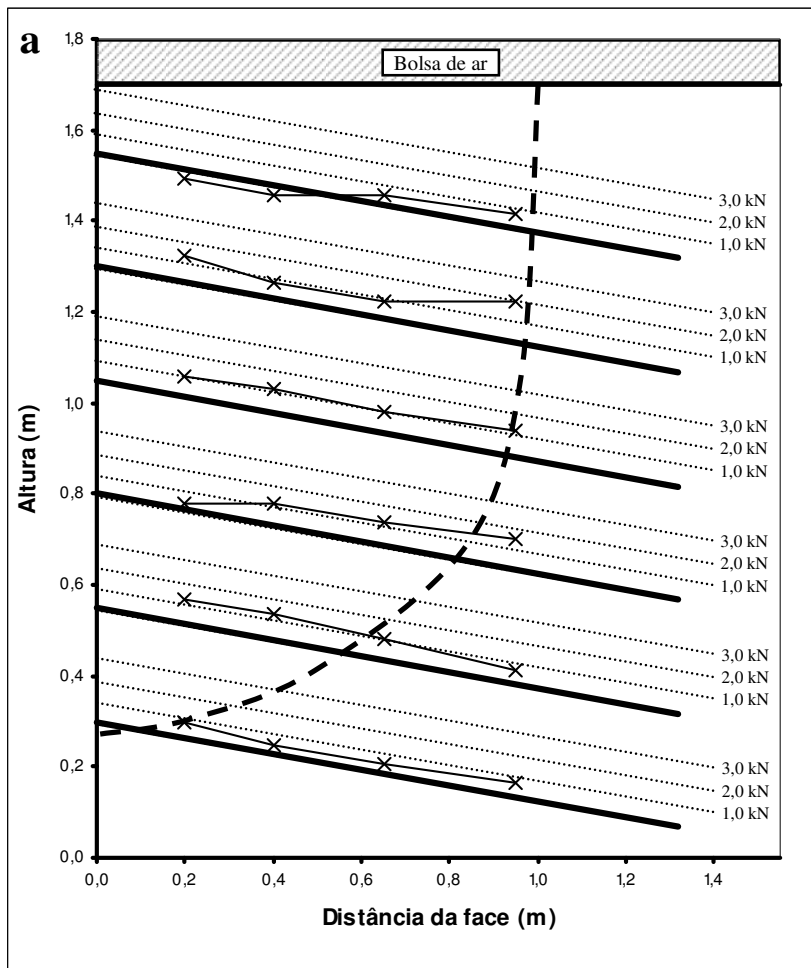

Após aplicação da sobrecarga

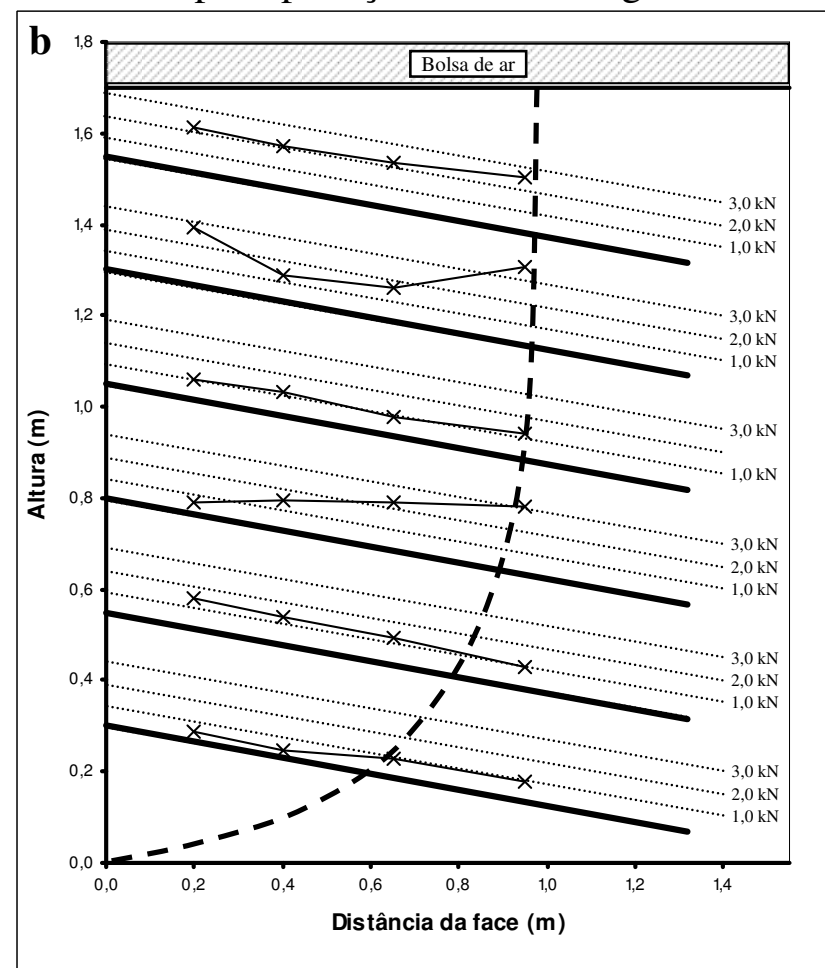

Figura 4.8 - Força de tração ao longo dos grampos. A linha tracejada indica a posição da superfície potencial de ruptura sugerida para cada situação: a - Fim de construção; b - Após aplicação da sobrecarga.

$\mathrm{Na}$ fase de construção, a forca de tração máxima ocorreu na linha $\mathrm{L}_{2}(1,7 \mathrm{kN})$. A mesma linha apresentou o maior esforço de tração após aplicação da sobrecarga $(3,4 \mathrm{kN})$. Verificou-se que a linha inferior $\left(\mathrm{L}_{6}\right)$ foi pouco solicitada nas duas situações analisadas (antes e após a aplicação da sobrecarga) conforme descrito anteriormente. A aplicação da sobrecarga levou a um aumento da força de tração mais expressiva nos grampos mais rasos. A força nos grampos da linha $L_{1}$ aumentou cerca de três vezes em relação ao valor verificado ao final da construção. Esse aumento foi da ordem de duas vezes para as linhas $\mathrm{L}_{2}, \mathrm{~L}_{3}$ e $\mathrm{L}_{4}$ e de cerca de $50 \%$ para os grampos das linhas $\mathrm{L}_{5}$ e $\mathrm{L}_{6}$.

As superfícies potenciais de ruptura para as duas situações apresentaram a forma de uma espiral logarítmica e permaneceram com uma forma semelhante nas duas situações 
analisadas, porém mais rasa para antes da aplicação da sobrecarga. A determinação da superfície potencial de ruptura é um parâmetro essencial para projetos, pois condiciona a análise da estabilidade da obra. 


\section{Capítulo 5 - Conclusões}

Esta dissertação apresentou a construção de um protótipo de solo grampeado construído em laboratório. O programa experimental permitiu a execução de ensaios de arrancamento dos grampos do protótipo e a verificação do seu comportamento no tocante aos deslocamentos do solo e às forças nos grampos.

As principais conclusões que podem ser estabelecidas a partir dos resultados são:

- Os ensaios de arrancamento resultaram em valores de resistência ao cisalhamento da interface solo-grampo igual a $144,7 \mathrm{kPa}$, dentro do intervalo previsto por Byrne et al. (1998) e de mesma ordem de grandeza para os grampos inseridos nas duas camadas de solo. O coeficiente de variação da resistência ao arrancamento dos grampos apresentou um valor aceitável (13\%), contudo, deve-se atentar para esse coeficiente em ensaios realizados em campo, devido à falta de controle das condições de contorno.

- O deslocamento necessário para a total mobilização da resistência ao cisalhamento de interface dos grampos submetidos aos ensaios de arrancamento mostrou-se da ordem de $0,24 \%$ do comprimento do grampo. 
- A partir do arrancamento dos grampos instrumentados, verificou-se que os grampos foram praticamente solicitados em todo o seu comprimento durante os ensaios de arrancamento.

- Os ensaios de arrancamento em dois ciclos de carregamento apresentaram-se como uma alternativa confiável quando o curso máximo do equipamento de medição dos deslocamentos do grampo não permite uma observação mais extensa dos ensaios.

- A extração completa dos grampos possibilitou uma análise qualitativa das condições dos grampos. Os grampos extraídos apresentaram-se íntegros e não foi possível correlacionar alguma falha executiva a uma redução na resistência ao cisalhamento de interface.

- O deslocamento do solo medido durante a construção foi máximo próximo à face do protótipo e na direção horizontal. Esse comportamento obedeceu às previsões feitas com base na literatura consultada. O deslocamento horizontal máximo foi da ordem de $0,07 \%$ da altura do protótipo.

- Os deslocamentos verticais máximos durante construção foram da ordem de 64\% dos deslocamentos horizontais máximos.

- Os deslocamentos horizontais, durante a construção, a uma distância de 750 $\mathrm{mm}$ da face do protótipo atingiram $48 \%$ dos deslocamentos horizontais máximos, próximos à face. Verificou-se também que os deslocamentos horizontais a $750 \mathrm{~mm}$ da face ocorreram apenas após a execução da quinta fase de escavação. Conclui-se, portanto, que, à medida que a escavação prossegue, os deslocamentos horizontais atingem regiões mais distantes da face.

- Os deslocamentos horizontais da face após a aplicação da sobrecarga apresentaram valores máximos a cerca de $80 \%$ da altura do protótipo e atingiram valores da ordem de $0,2 \%$ da sua altura. 
- Verificou-se que a força de tração nos grampos aumentou durante a construção do protótipo e, sobretudo, com a aplicação da sobrecarga. O incremento foi mais expressivo nos grampos superiores, apresentando taxas de incremento inversamente proporcionais à profundidade dos grampos. A linha $\mathrm{L}_{6}$ de grampos não apresentou variações efetivas de força nos grampos.

- As superfícies potenciais de ruptura sugeridas apresentaram a forma de uma espiral logarítmica e se mostraram com forma semelhante para as duas situações estudadas (antes e após a aplicação da sobrecarga). Contudo, a superfície sugerida para antes da sobrecarga apresentou-se mais rasa, com pouca inserção na camada de solo mais compacta. 


\section{REFERÊNCIAS}

AZAMBUJA, E.; STRAUSS, M.; SILVEIRA, F. G. Caso histórico de um sistema de contenção em solo grampeado em Porto Alegre, RS. In: Conferência Brasileira Sobre Estabilidade de Encostas, 3., 2001, Rio de Janeiro, Anais..., Rio de Janeiro: Associação Brasileira de Mecânica dos Solos e Engenharia Geotécnica, 2001. p. 435-443.

BRIDLE, R. J.; DAVIES, M. C. R. Analysis of soil nailing using tension and shear: experimental observations and assessment. Geotechnical Engineering. v. 125, p. 155-167, jul. 1997.

BRUCE, D. A.; JEWELL, R. A. Soil Nailing: application and practice - part 1. Ground Engineering, Londres, v. 19, n. 8, p. 10-15, nov. 1986.

BRUCE, D. A.; JEWELL, R. A. Soil Nailing: application and practice - part 2. Ground Engineering, Londres, v. 20, n. 1, p. 21-34, jan. 1987.

BYRNE, R. J. et al. Manual for design and contruction monitoring of soil nail wall. Report No. FHWA-SA-96-069R. Washington, 568p. 1998.

CARTIER, G.; GIGAN, J.P. Experiments and Observations on Soil Nailing Structures. In: $8^{\text {th }}$ European Conference on Soil Mechanics and Foundation Engineering,1983, Helsinki, Anais..., Helsinki: International Society of Soil Mechanics and Fundation Engineering, 1983. p. 473-476.

CHENG, S.; HANSEN, L. Design, construction and performance of a soil nailed wall in Puerto Rico. Geotechnical Special Publication No. 42, New York, p. 1-16, 1994.

CHU, L.M.; YIN, J. H. A laboratory device to test the pull-out behavior of soil nails. Geotechnical Testing Journal, West Conshohocken, v. 28, n. 5, p. 499-513, set. 2005.

DIAS, P. H. V. Solo pregado: procedimento sugestão de norma. In: Conferência Brasileira Sobre Estabilidade de Encostas, 1., 1992, Rio de Janeiro, Anais..., Rio de Janeiro: Associação Brasileira de Mecânica dos Solos e Engenharia Geotécnica, 1992. p. 75-80. 
EHRLICH, M. Solos Grampeados: comportamento e procedimentos de análise. In: Workshop Solo Grampeado: Projeto, Execução, Instrumentação e Comportamento, 2003, Anais... São Paulo: Associação Brasileira de Mecânica dos Solos e Engenharia Geotécnica, 2003. p. 127138.

EHRLICH, M.; SILVA, L. F. M. Sistemas de contenção de solos reforçados. In: Conferência Brasileira Sobre Estabilidade de Encostas, 1., 1992, Rio de Janeiro, Anais..., Rio de Janeiro: Associação Brasileira de Mecânica dos Solos e Engenharia Geotécnica, 1992. p. 35-45.

FALCONI, F. F.; ALONSO, U. R. Controle de qualidade em estruturas de contenção em solo grampeado. In: Conferência Brasileira Sobre Estabilidade de Encostas, 2., 1997, Rio de Janeiro, Anais..., Rio de Janeiro: Associação Brasileira de Mecânica dos Solos e Engenharia Geotécnica, 1997. p. 613-618.

FEIJÓ, R. L.; EHRLICH, M. Resultados do monitoramento de uma obra experimental em solo grampeado. In: Conferência Brasileira Sobre Estabilidade de Encostas, 4., 2005, Salvador, Anais..., Salvador: Associação Brasileira de Mecânica dos Solos e Engenharia Geotécnica, 2005. p. 633-642.

FRENCH NATIONAL RESEARCH PROJECT CLOUTERRE. Recommendations CLOUTERRE - 1991 for designing, calculating, constructing and inspecting earth support systems using soil nailing. Tradução: Federal Highway Administration. Paris: Presses de L'ecole Nationale des Ponts et Chaussees, 1991. 302 p.

GÄSSLER, G.; GUDEHUS, G. Soil nailing: some aspects of a new technique. In: International Conference on Soil Mechanics and Foundation Engineering, 8., 1981, Estocolmo, Anais..., Estocolmo: International Society of Soil Mechanics and Foundation Engineering, 1981.p. 665-670.

GÄSSLER, G.; GUDEHUS, G. Soil nailing: statistical design. In: European Conference on Soil Mechanics and Foundation Engineering, 8., 1983, Helsinque, Anais..., Helsinque: International Society of Soil Mechanics and Foundation Engineering, 1983 p. 491-494.

GERSCOVICH, D. M. S. et al. Técnicas de modelagem numérica de escavações de taludes em solo grampeado. In: Conferência Brasileira Sobre Estabilidade de Encostas, 4., 2005, Salvador, Anais..., Salvador: Associação Brasileira de Mecânica dos Solos e Engenharia Geotécnica, 2005. p. 643-655. 
GUILLOUZ, A.; SCHLOSSER, F. Soil nailing: practical applications. In: Symposium on Recent Developments in Ground Improvement Techniques, 1982, Bangkok, Anais..., Bangkok: Asian Institute of Technology, 1982. p. 389-397.

GUILLOUX, A.; NOTTE, G.; GONIN, H. Experiences on a retaining structure by nailing in moraine soils. In: European Conference on Soil Mechanics and Foundation Engineering, 8., 1983, Helsinque, Anais..., Helsinque: International Society of Soil Mechanics and Foundation Engineering, 1983. p. 499-502.

INGOLD, T. S.; MYLES, B. Ballistic soil nailing. In: Earth Reinforcement, 1996, Fukuoka, Anais..., Fukuoka: Japanese Geotechnical Society, 1996. p. 765-770.

JAMES, R. G. Some aspects of soil mechanics model testing. In: Roscoe Memorial Symposium, 1971, Cambridge, Anais..., Cambridge: G. T. Foulis, 1971. p. 417-440.

JUNAIDEEN, S. et al. Laboratory study of soil-nail interaction in loose, completely decomposed granite. Canadian Geotechnical Journal, n. 41, p. 274-286, 2004.

JURAN, I. et al. Study of soil-bar interaction in the technique of soil nailing. In: European Conference on Soil Mechanics and Foundation Engineering, 8., 1983, Helsinque, Anais..., Helsinque: International Society of Soil Mechanics and Foundation Engineering, 1983. p. 513-516.

JURAN, I.; ELIAS, V. Ground anchors and soil nails in retaining structures. In: DAY, R. W. Foundation Engineering Handbook. Reston: McGraw-Hill, 1991. p.868-905.

KIM, D. S. et al. Model study on the failure mechanism of soil nailed structure under surcharge loading. Geotechnical Testing Journal, West Conshohocken, v. 18, n. 4, p. 421430, dec. 1995.

MYLES, B.; BRIDLE, R. J. Fired soil nails. In: Earth Reinforcement Practice, 1992, Fukuoka, Anais..., Fukuoka: Japanese Society of Soil Mechanics and Foundation Engineering, 1992. p. 509-514.

OLIVEIRA, V. S.; FERREIRA, R. S.; OLIVEIRA, H. R. Análise de estabilidade no estudo de talude em solo grampeado. In: Conferência Brasileira Sobre Estabilidade de Encostas, 4., 2005, Salvador, Anais..., Salvador: Associação Brasileira de Mecânica dos Solos e Engenharia Geotécnica, 2005. p. 621-632. 
ORTIGÃO, J. A. R.; PALMEIRA, E. M.; ZIRLIS, A. C. Experience with soil nailing in Brazil: 1970 - 1994. Geotechnical Engineering., v. 113, p. 93-106, abril 1995.

PITTA, C. A.; SOUZA, G. J. T.; ZIRLIS, A. C. Solo Grampeado: alguns detalhes executivos, ensaios, casos de obras. In: Workshop Solo Grampeado: Projeto, Execução, Instrumentação e Comportamento, 2003, Anais... São Paulo: Associação Brasileira de Mecânica dos Solos e Engenharia Geotécnica, 2003. p. 1-20.

RAJU, G. V. R.; WONG, I. H.; LOW, B. K. Experimental nailed soil walls. Geotechnical Testing Journal, v. 20, n. 1, p. 90-102, mar. 1997.

SARAMAGO, R. P. et al. Muro de solo grampeado com face em blocos pré-moldados. In: Conferência Brasileira Sobre Estabilidade de Encostas, 4., 2005, Salvador, Anais..., Salvador: Associação Brasileira de Mecânica dos Solos e Engenharia Geotécnica, 2005. p. 827-833.

SCHLOSSER, F. Behaviour and design of soil nailing. In: Symposium on Recent Developments in Ground Improvement Techniques, 1982, Bangkok, Anais..., Bangkok: Asian Institute of Technology, 1982. p. 399-413.

SCHLOSSER, F. et al. Failure of a full scale experimental soil nailed wall by reducing the nail lengths (French research project CLOUTERRE). In: Earth Reinforcement Practice, 1992, Fukuoka, Anais..., Fukuoka: Japanese Society of Soil Mechanics and Foundation Engineering, 1992. p. 531-535.

SCHLOSSER; F.; DE BUHAN, P. Theory and design related to the performance of reinforced soil structures. In: International Reinforced Soil Conference Organized by the British Geotechnical Society, 1990, Londres, Anais..., Londres: British Geotechnical Society, 1990. p. 1-14.

SHEN, C. K.; BANG, S.; HERRMAN, L. R. Ground movement analysis of earth support system. Journal of the Geotechnical Engineering Division. v. 107, n. GT12, p. 1609-1624, dez. 1981.

SHEN, C. K. et al. Field measurements of an earth support system. Journal of the Geotechnical Engineering Division. v. 107, n. GT12, p. 1625-1642, dez. 1981.

SMITH, M. J. The effects of variable geology on soil nail pullout test result in Hong Kong. In: Earth Reinforcement Practice, 1992, Fukuoka, Anais..., Fukuoka: Japanese Society of Soil Mechanics and Foundation Engineering, 1992. p. 543-548. 
SOLOTRAT ENGENHARIA GEOTÉCNICA. Manual Técnico. São Paulo: Solotrat Engenharia Geotécnica, 2003. p. 5-15.

SPRINGER, F. O.; GERSCOVICH, D. M. S.; SAYÃO, A. S. F. J. Deformabilidade de taludes estabilizados com solo grampeado. In: Conferência Brasileira Sobre Estabilidade de Encostas, 3., 2001, Rio de Janeiro, Anais..., Rio de Janeiro: Associação Brasileira de Mecânica dos Solos e Engenharia Geotécnica, 2001. p. 483-490.

TEI, K.; TAYLOR, R.; MILLIGAN, G. Centrifuge model tests of nailed soil slopes. Soils and Foundation, v. 38, n. 2, p. 165-177, jun. 1998.

VERTEMATTI, J. C. Manual Brasileiro de Geossintéticos. São Paulo: Edgard Blücher, 2004.

VIANA, P. M. F. Geovala: Um novo processo construtivo para dutos enterrados. 2003. Tese (Doutorado em Geotecnia) - Departamento de Geotecnia, Escola de Engenharia de São Carlos, Universidade de São Paulo, São Carlos, 2003.

VUCETIC, M.; TUFENKJIAN, M. R.; DOROUDIAN, M. Dynamic centrifuge testing of soil nailed excavations. Geotechnical Testing Journal, West Conshohocken, v. 16, n. 2, p. 172187, jun. 1993.

WONG, I. et al. Field performance of nailed soil wall in residual soil. Journal of Performance of Constructed Facilities, v. 11, n. 3, p. 105-112, ago. 1997.

ZHANG, J. et al. Model tests by centrifuge of soil nail reinforcements. Journal of Testing and Evaluation, v. 29, n. 4, p. 315-328, jul. 2001.

ZIRLIS, A. C.; PITTA, C. A. Soil nailing: chumbamento de solos experiência de uma equipe na aplicação do método. In: Conferência Brasileira Sobre Estabilidade de Encostas, 1., 1992, Rio de Janeiro, Anais..., Rio de Janeiro: Associação Brasileira de Mecânica dos Solos e Engenharia Geotécnica, 1992. p. 81-99. 